University of Nebraska - Lincoln

DigitalCommons@University of Nebraska - Lincoln

Publications from USDA-ARS / UNL Faculty

U.S. Department of Agriculture: Agricultural

Research Service, Lincoln, Nebraska

2020

\title{
Contributions in Puerto Rico to Bean, Phaseolus spp., Research
}

James S. Beaver

University of Puerto Rico-Mayagüez, james.beaver@upr.edu

Consuelo Estévez de Jensen

University of Puerto Rico-Mayagüez, ecafss@uprm.edu

Phillip N. Miklas

USDA-ARS, phil.miklas@ars.usda.gov

Timothy G. Porch

USDA-ARS, Tropical Agriculture Research Station, timothy.porch@usda.gov

Follow this and additional works at: https://digitalcommons.unl.edu/usdaarsfacpub

Part of the Agriculture Commons, and the Agronomy and Crop Sciences Commons

Beaver, James S.; Estévez de Jensen, Consuelo; Miklas, Phillip N.; and Porch, Timothy G., "Contributions in Puerto Rico to Bean, Phaseolus spp., Research" (2020). Publications from USDA-ARS / UNL Faculty. 2401. https://digitalcommons.unl.edu/usdaarsfacpub/2401

This Article is brought to you for free and open access by the U.S. Department of Agriculture: Agricultural Research Service, Lincoln, Nebraska at DigitalCommons@University of Nebraska - Lincoln. It has been accepted for inclusion in Publications from USDA-ARS / UNL Faculty by an authorized administrator of DigitalCommons@University of Nebraska - Lincoln. 


\title{
Feature
}

\section{Contributions in Puerto Rico to Bean, Phaseolus spp., Research ${ }^{1,2}$}

\author{
James S. Beaver ${ }^{3}$, Consuelo Estévez de Jensen ${ }^{4}$, \\ Phillip N. Miklas ${ }^{5}$ and Timothy G. Porch ${ }^{6}$
}

\section{J. Agric. Univ. P.R. 104(1):43-111 (2020)}

Most literature reviews focus on a specific topic. The purpose of this paper, however, is to review the contributions made by a multidisciplinary team of researchers at a specific location (Puerto Rico) over a period of several decades. This paper documents bean research of the University of Puerto Rico and the USDA-ARS Tropical Agriculture Research Station during the past century. The following illustrates the merits of continuity of effort in research and shows that research often follows a logical sequence of actions to solve problems related to genetic improvement as well as to study biotic and abiotic factors that affect common bean production in Central America and the Caribbean. Finally, this narrative demonstrates that the ongoing development of improved bean germplasm lines and cultivars is cyclical and builds upon previous research achievements.

\section{INTRODUCTION}

The common bean (Phaseolus vulgaris L.) is an important component of the traditional diet in Puerto Rico. The 1900 report of the USDA Puerto Rico Agricultural Experiment Station (USDA-PRAES) noted that rice and beans were staple crops in Puerto Rico and found on the tables of both the rich and poor. Smit et al. (2007) noted that annual per capita consumption of grain legumes, mostly dry beans, in

${ }^{1}$ Manuscript submitted to Editorial Board 30 May 2019.

${ }^{2}$ This work was partially supported by the USDA National Institute of Food and Agriculture, Regional Hatch project W3150: Breeding Common Bean (Phaseolus vulgaris L.) for Resistance to Abiotic and Biotic Stresses, Sustainable Production, and Enhanced Nutrition.

${ }^{3}$ Professor Ad-Honorem, Dept. of Agroenvironmental Sciences, University of Puerto Rico-Mayagüez, P.O. Box 9000, Mayagüez, Puerto Rico 00681-9000.

${ }^{4}$ Professor, Dept. of Agroenvironmental Sciences, University of Puerto Rico-Mayagüez.

${ }^{5}$ USDA-ARS-GLGPRU, 24106 N. Bunn Road, Prosser, WA 99350-9687.

${ }^{6}$ USDA-ARS-TARS, 2200 P.A. Campos Ave., Suite 201, Mayagüez, PR 00680. 
Puerto Rico $(6.4 \mathrm{~kg})$ is almost double the per capita consumption in the U.S. (3.4 kg; US Dry Bean Council, 2019).

Common and lima beans (Phaseolus lunatus L.) have been produced in the Caribbean for at least 500 years. The grain legume fits well into rotations and is often intercropped with other longer season crops such as plantains and bananas. Small white beans, locally known as 'Blanca del País' and striped pink beans known as 'Colorado del País' are traditional market classes in Puerto Rico (Koenig, 1953). Consumers in Puerto Rico today consume a wide array of market classes including white, red, pink, pinto, black and kidney beans (Bean Institute, 2018). Although Puerto Ricans represent roughly $1 \%$ of the U.S. population, they consume $3.1 \%$ of the common and lima beans in the U.S. (Lucier et al., 2000).

Snyder noted in the 1916 report of the USDA-PRAES that 47,200 ha of beans and cowpeas were planted (Snyder, 1918). Approximately $50 \%$ of the plantings were white beans, $25 \%$ were red beans and $25 \%$ were cowpeas [Vigna unguiculata (L.) Walp]. Picó(1937) reported that in 1929, a total of 13,360 ha of dry beans were planted in Puerto Rico. In 1950-1951, dry beans were harvested on the island from 11,429 ha, although seed yields only averaged $375 \mathrm{~kg} / \mathrm{ha}$ (Koenig, 1953).

Puerto Rico has imported grain legumes for over 100 years. In 1891, Puerto Rico imported from the U.S. 15,751 bushels of beans and peas having a value of $\$ 28,497$ (U.S. Treasury Dept., 1893). Almost all the dry beans currently consumed in Puerto Rico are imported, although the potential for increased local production exists. Using recommended practices and improved cultivars, it is currently feasible to produce an average bean seed yield of $2,000 \mathrm{~kg} / \mathrm{ha}$. Therefore, it would be possible to produce on approximately 2,000 ha the same amount of dry beans that was produced in Puerto Rico in 1950-1951. Most beans in Puerto Rico are currently harvested near physiological maturity as green-shelled beans. In 2012, a total of 573 farms reported planting green-shelled or dry beans on 320 ha resulting in a production of 301 MT (USDA-NASS, 2012).

González-Ríos and Riollano (1951) noted that the evaluation of bean germplasm in Puerto Rico was initiated by McClelland in 1918. Nineteen bean cultivars from the U.S., the Dominican Republic, Venezuela and Puerto Rico were evaluated at the USDA-PRAES. Cultivars from the tropics were reported to be better adapted than cultivars from the U.S.; 'Blanca del País' and 'Negra de Venezuela' were among the most productive cultivars. González-Ríos and Riollano (1951) reported that in 1922 white bean breeding lines were developed from crosses between those cultivars. Seed of the most promising breeding lines from those crosses were distributed to farmers in Puerto Rico. After 1923, 
the focus of bean research at the USDA-PRAES in Mayagüez switched to snap bean improvement.

In the 1930s, the University of Puerto Rico Agricultural Experiment Station (UPR AES) initiated a project to improve the yield potential and quality of white and striped pink bean cultivars for Puerto Rico (González-Ríos and Riollano, 1951). Seed samples of bean landraces were obtained from farmers. The collection of bean landraces was initially evaluated in plant rows. Between 1938 and 1941, approximately 2,000 selections were evaluated. Three lines were identified as having superior seed yield and agronomic characteristics. During the first year of World War II, 2,250 kg of seed of these lines were distributed to farmers to help alleviate food shortages. In 1945, seven other lines were selected for evaluation in yield trials. The selection No. 1632, which had the highest seed yield potential, was released as 'Bonita' (González-Ríos and Riollano, 1951). This remained the standard white bean variety in Puerto Rico until the 1980s.

Walter J. Kaiser and Nader Vakili, plant pathologists, were transferred from the USDA-ARS Regional Pulse Improvement Project in Tehran, Iran, to the USDA-ARS Mayagüez Institute of Tropical Agriculture (ARS-MITA) in the early 1970s. During the 1970s, the University of Puerto Rico and the ARS-MITA participated in a collaborative research project supported by the U.S. Agency for International Development (USAID). The project was entitled "Improvement of Tropical Production of Beans and Cowpeas through Disease and Insect Control". Nader Vakili and George Freytag, USDA-ARS plant geneticist, developed and released more than 25 improved bean germplasm lines (http://arsftfbean.uprm.edu/bean/?p=893). The release of improved germplasm by USDA-ARS bean research geneticists in Puerto Rico has continued to date (Table 1).

Freytag maintained and evaluated a collection of many different species of the genus Phaseolus. These evaluations were used in the development of the comprehensive book titled "Taxonomy, Distribution, and Ecology of the Genus Phaseolus (Leguminosae-Papilionoideae) in North America, Mexico and Central America", which was published in collaboration with Daniel Debouck, curator of the bean germplasm collection at the International Center for Tropical Agriculture (CIAT) (Freytag and Debouck, 2002).

In 1981, The University of Puerto Rico Agricultural Experiment Station and the USDA ARS-MITA, renamed Tropical Agriculture Research Station (ARS-TARS), received a grant from the Bean/Cowpea CRSP (Collaborative Research Support Program) which was financed by USAID. The objective of this research and training project was to improve bean research capabilities in Honduras and the Dominican 


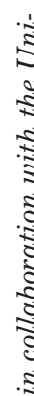

竎

密

ณึ้

范

赵

वै.

$\approx$

苋

胥

密

है

की

కี

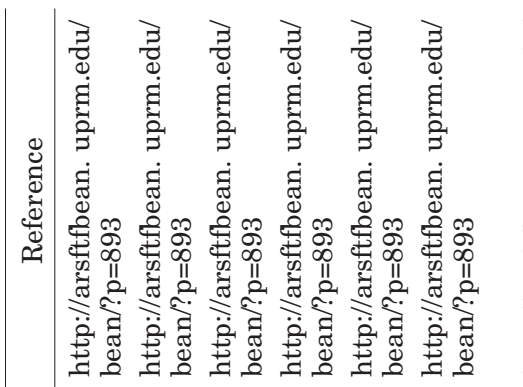

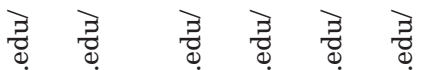

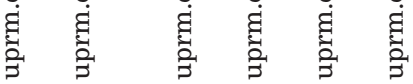

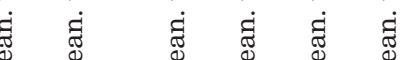

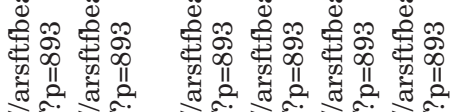

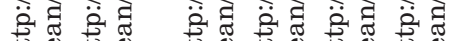
$\begin{array}{lllllll} & & & & \\ 0\end{array}$

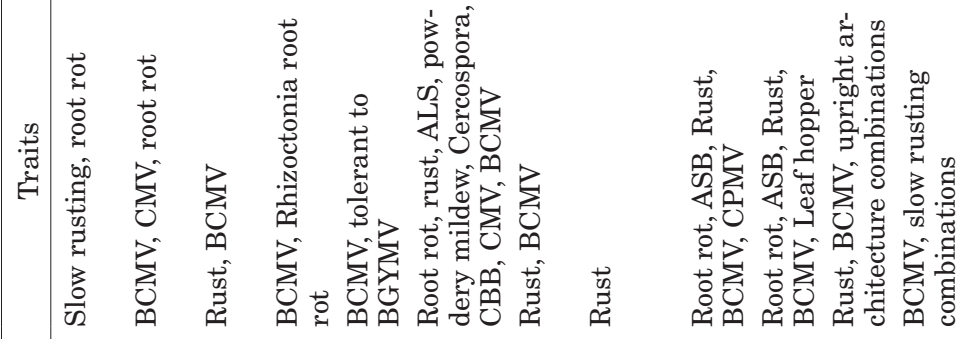

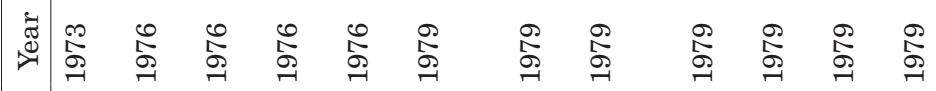

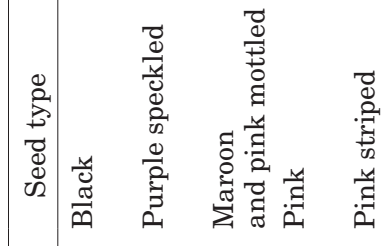

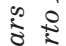

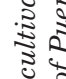
เัต

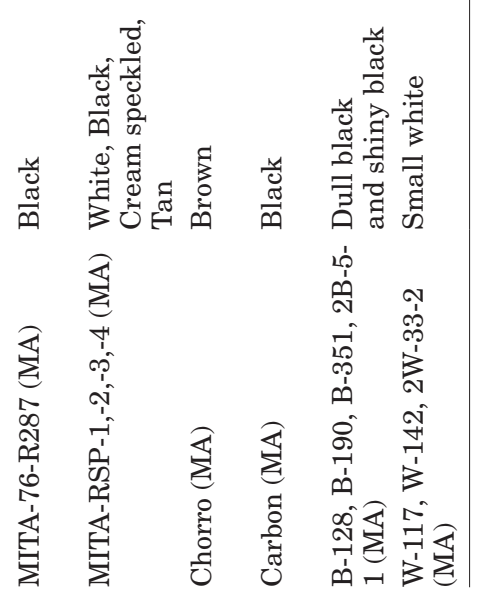


J. Agric. Univ. P.R. voL. 104, No. 1, 2020

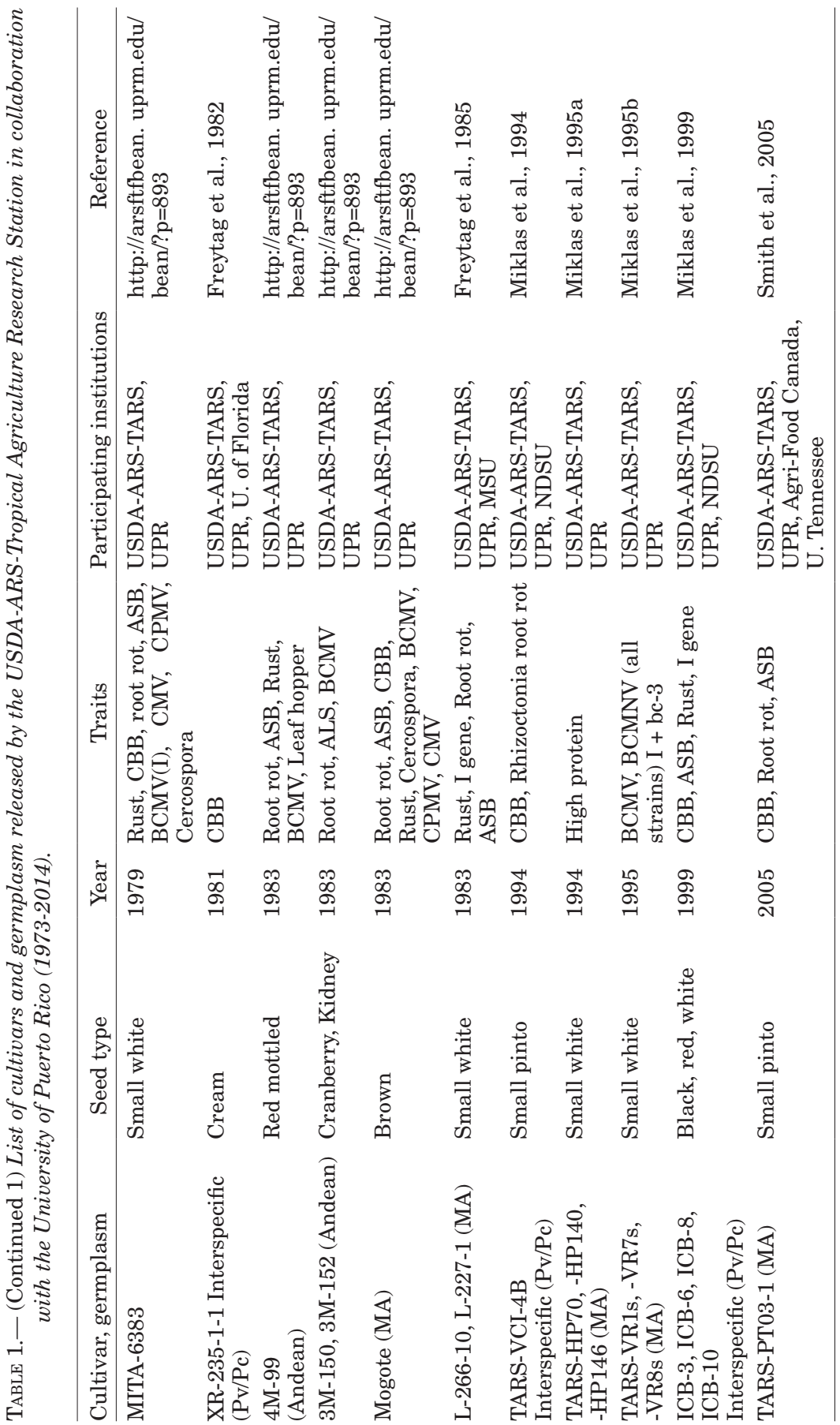




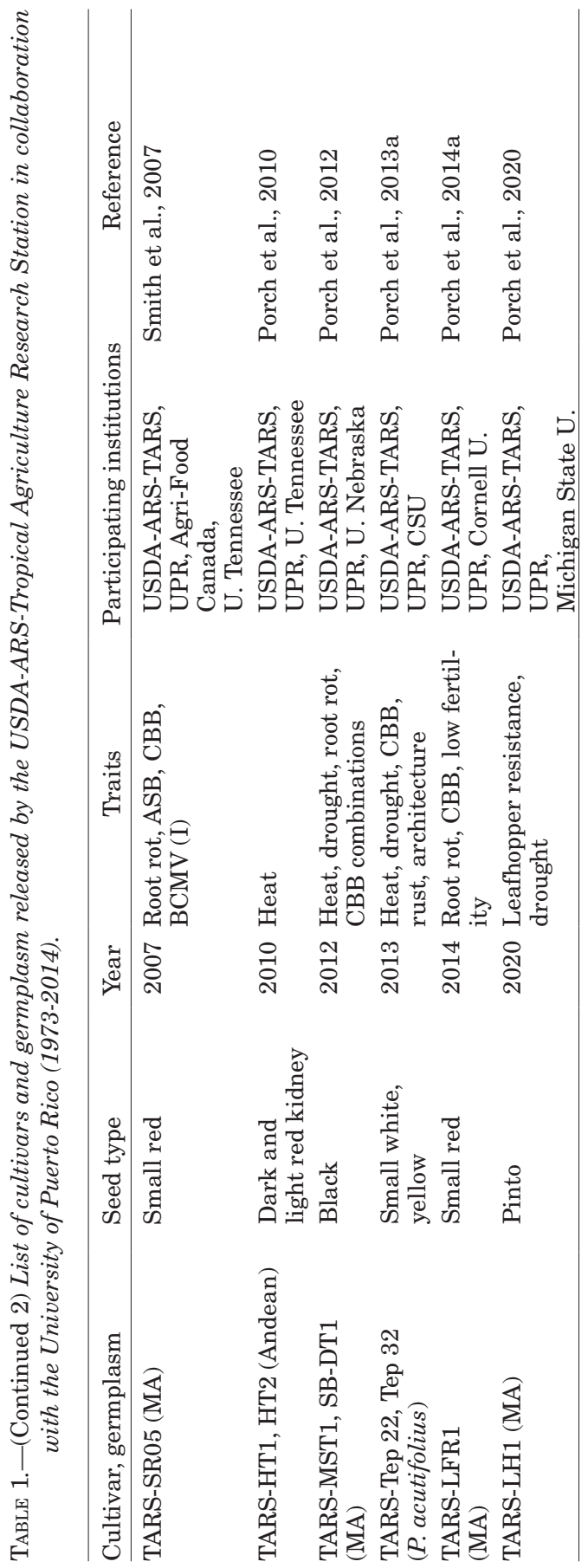


Republic. The Bean/Cowpea CRSP project initially collaborated with researchers at the 'Escuela Agrícola Panamericana' (EAP) in Zamorano, Honduras, and the 'Secretaría de Agricultura' in the Dominican Republic. Graduate training in plant breeding and plant pathology was an important objective of this project and, since 1981, more than 60 students from Central and South America, the Caribbean and the U.S. have received M.S. degree training at the University of Puerto Rico, Mayagüez Campus, with full or partial support from projects funded by USAID (Table 2). A more regional focus evolved as the Bean/ Cowpea CRSP project matured. Collaboration with bean researchers in Haiti and Central America was strengthened (Beaver et al., 2003). The University of Puerto Rico and the ARS-TARS bean research programs participated in the development and release of numerous cultivars that are widely used in Central America and the Caribbean and as parental materials in North America (Table 3). The UPR bean research program also received long-term support from Regional Hatch Projects W-150, W-1150, W-2150, W-3150 (https://www.nimss.org/) that facilitated collaborations with Phaseolus researchers in the U.S. and led to the development of germplasm and scientific findings. The long-term commitment of the USDA-ARS to support a bean research geneticist at the Tropical Agriculture Research Station provided continuity of effort in the improvement of Phaseolus spp. germplasm for the tropics and the United States.

Since the 1970s, disease resistance has been a major focus of bean research in Puerto Rico. Climatic differences during the year and contrasting ecological zones permit bean researchers in the Caribbean to screen for resistance to different diseases and pests in different seasons of the year (Beaver et al., 1985b). Koenig (1953) reported that anthracnose caused by Colletotrichum lindemuthianum was the most common bean disease in Puerto Rico in the mid-20th century. Warmer weather patterns and the production of disease-free seed has eliminated this disease as a constraint to bean production in Puerto Rico. Researchers have responded to the emergence of new diseases. The study of virulence patterns of pathogens, the development of improved screening techniques and, in recent years, the development of molecular markers linked to disease resistance genes supported the effort to develop beans with enhanced levels of disease resistance (Beaver and Osorno, 2009). The development of bean germplasm with enhanced levels of tolerance to abiotic stresses, such as high temperature, drought and low soil fertility, has become an important breeding objective for the bean research programs in Puerto Rico. The following sections will summarize the achievements of researchers in Puerto Rico dealing with some of the most important constraints to bean production in the tropics. 


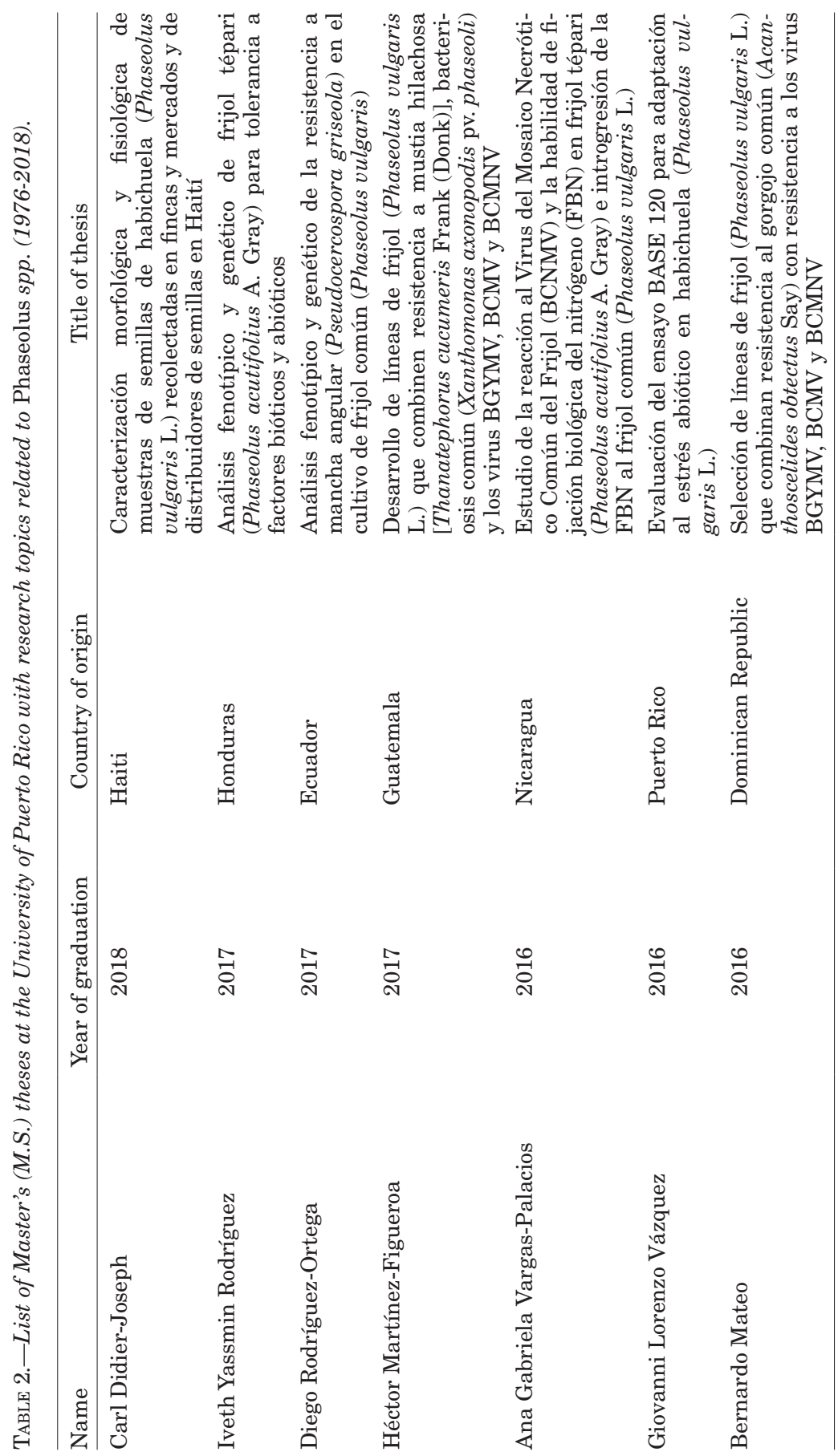


J. Agric. Univ. P.R. vol. 104, No. 1, 2020

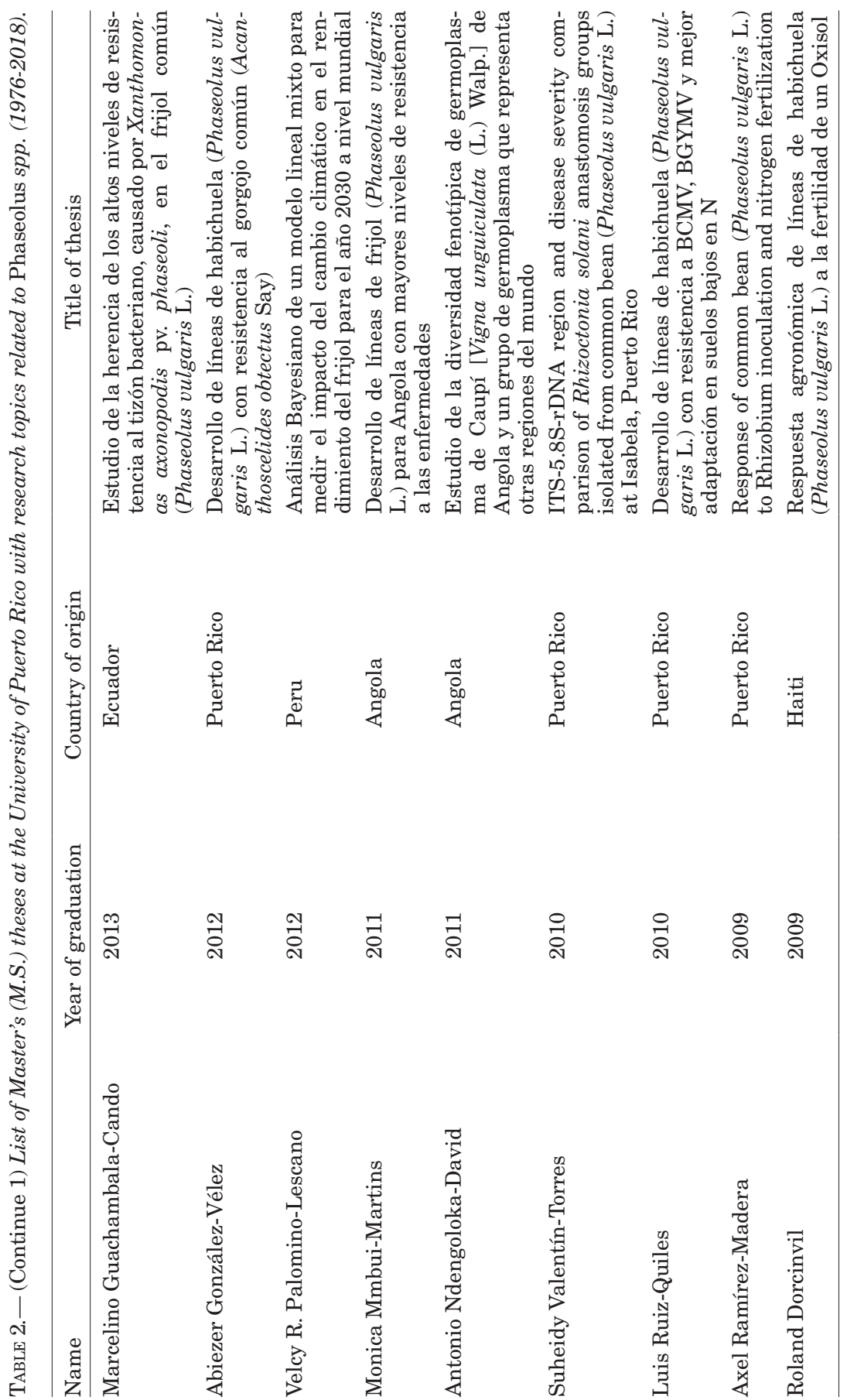




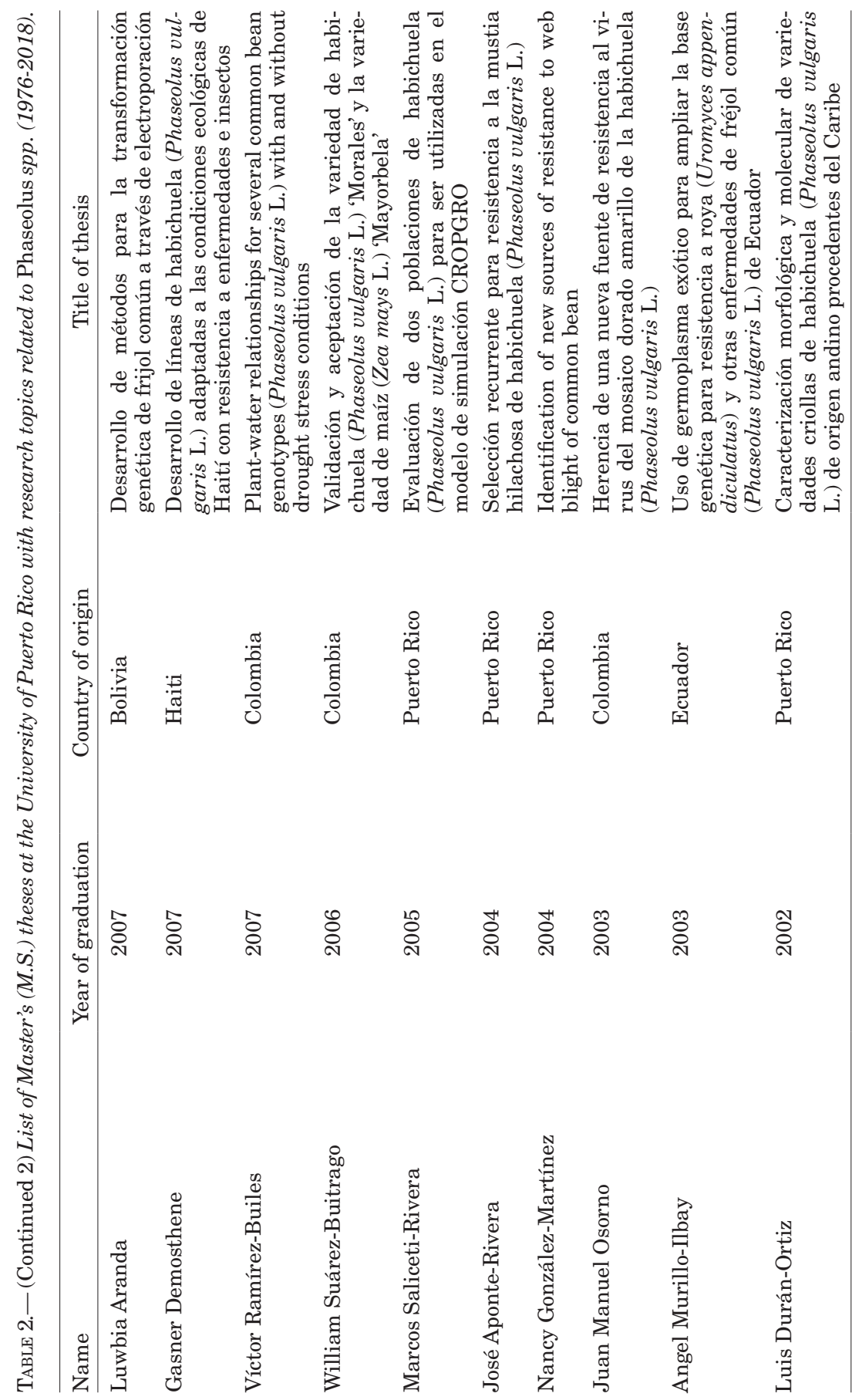


J. Agric. Univ. P.R. vol. 104, No. 1, 2020

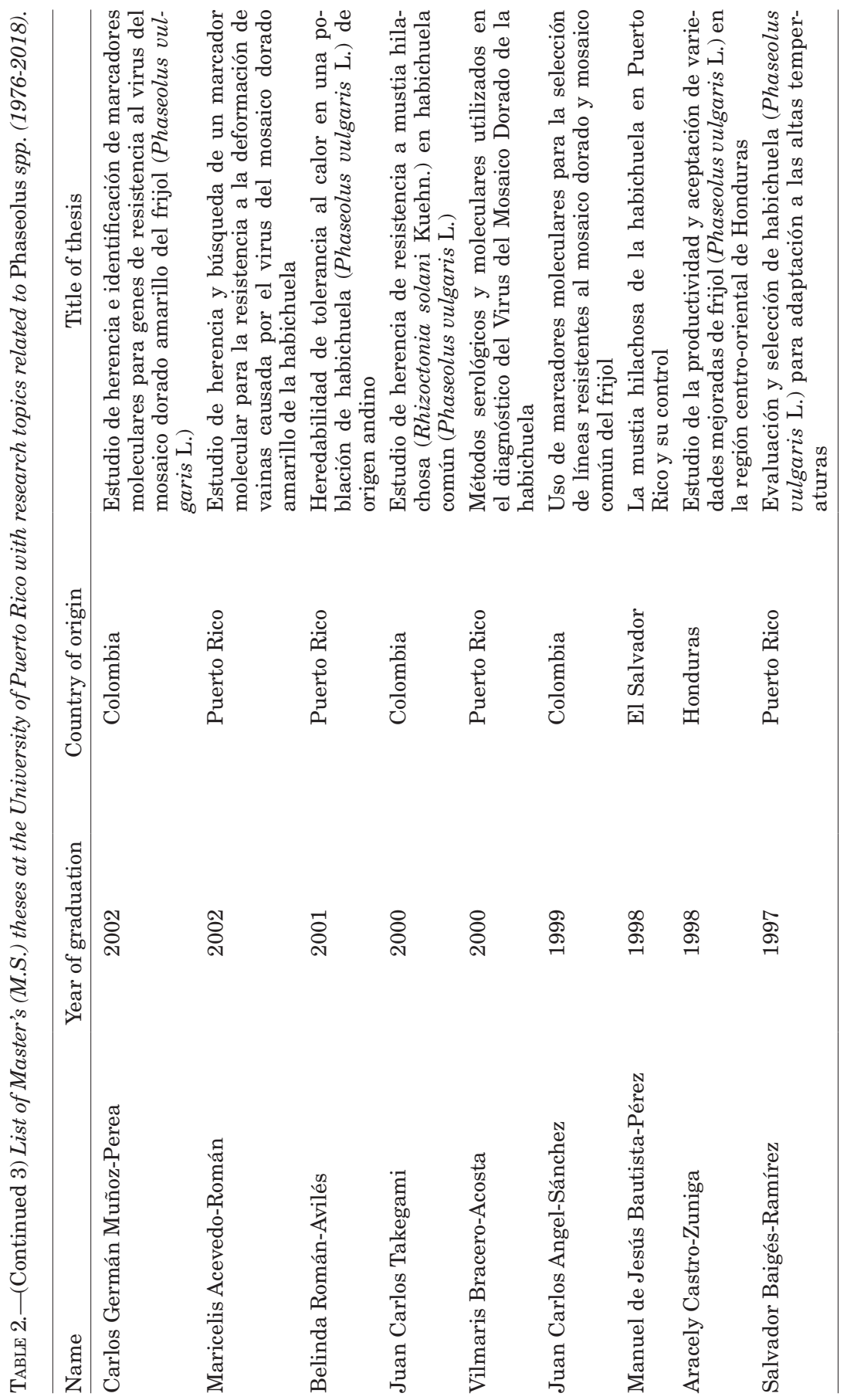




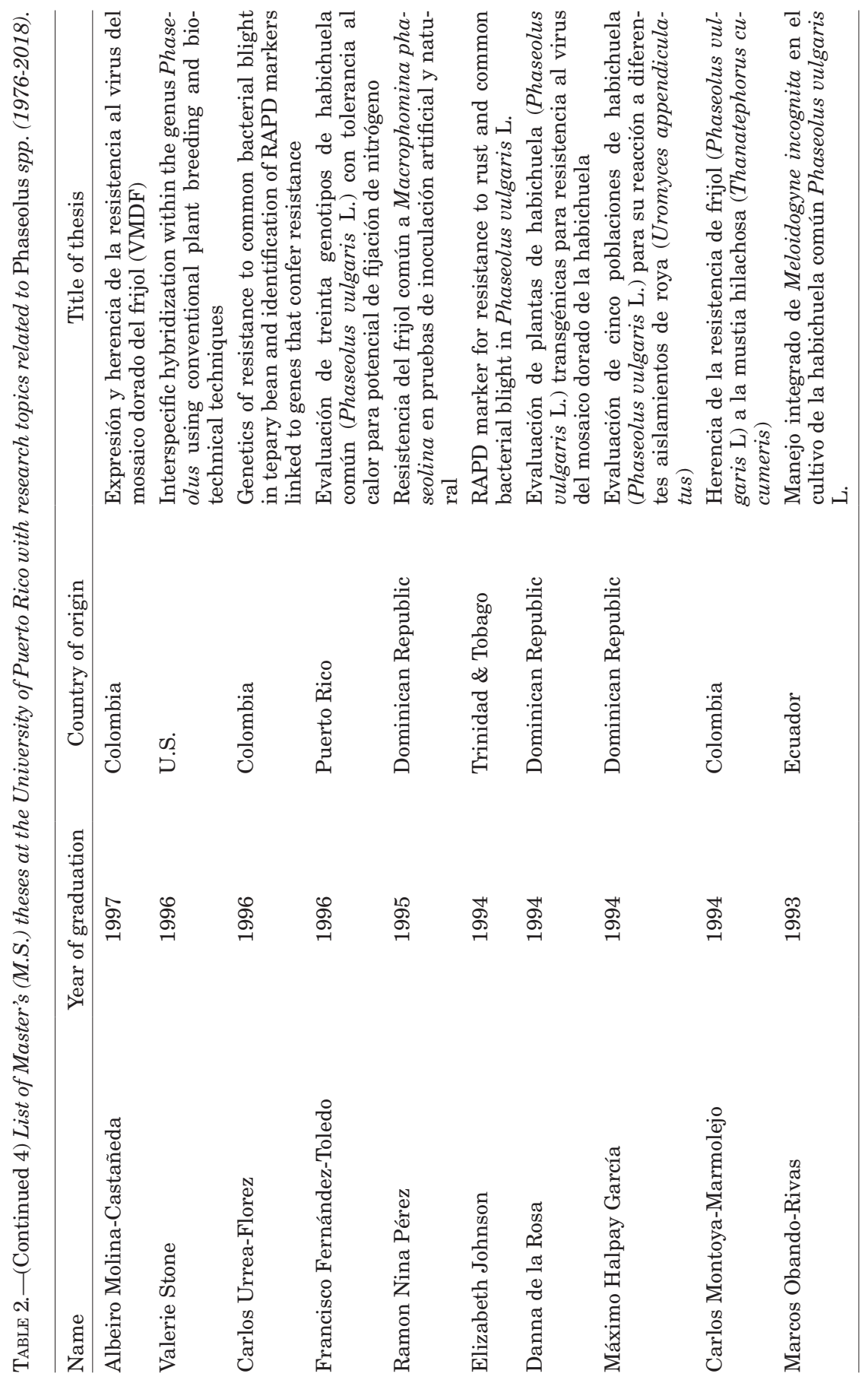


J. Agric. Univ. P.R. vol. 104, No. 1, 2020

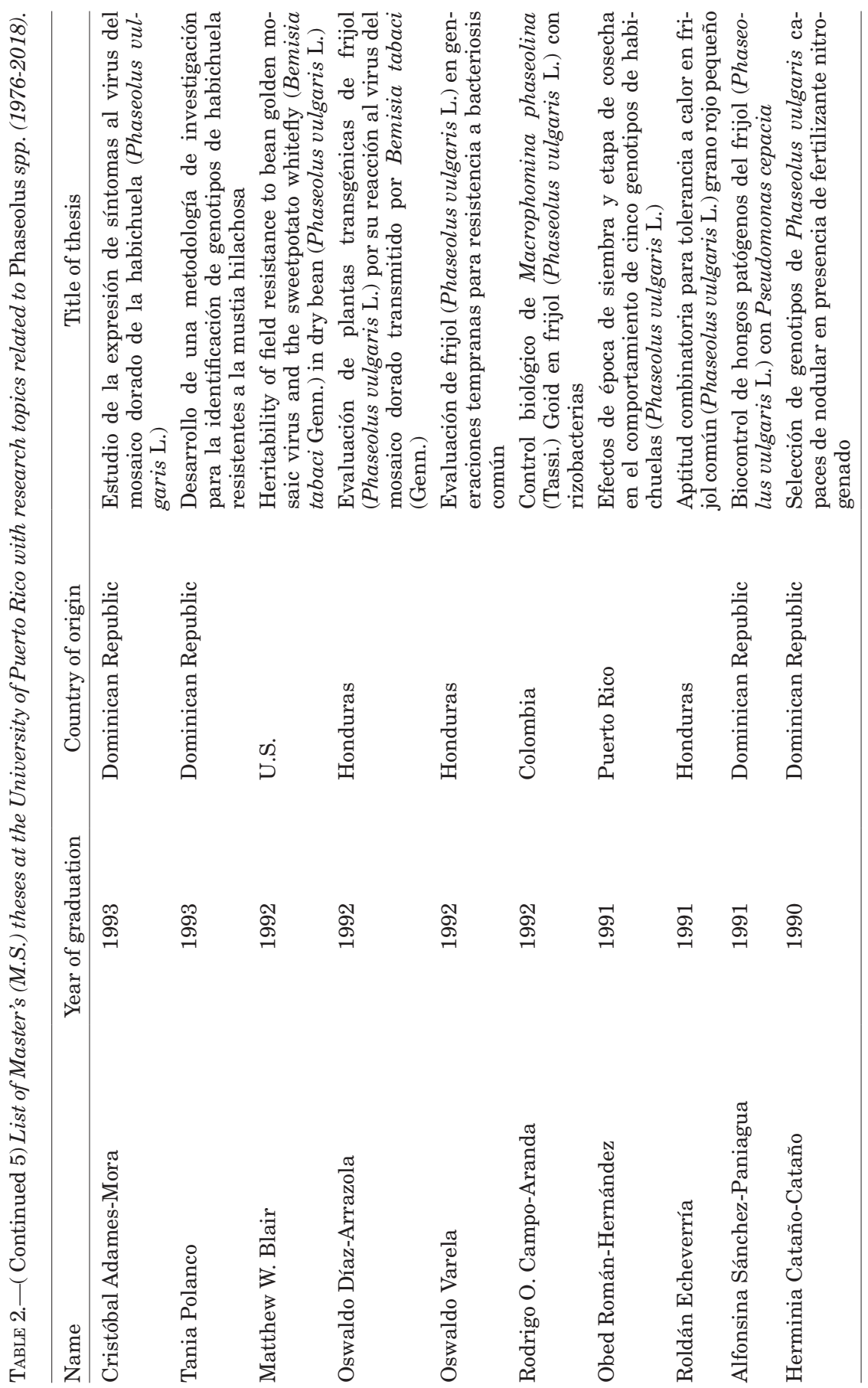




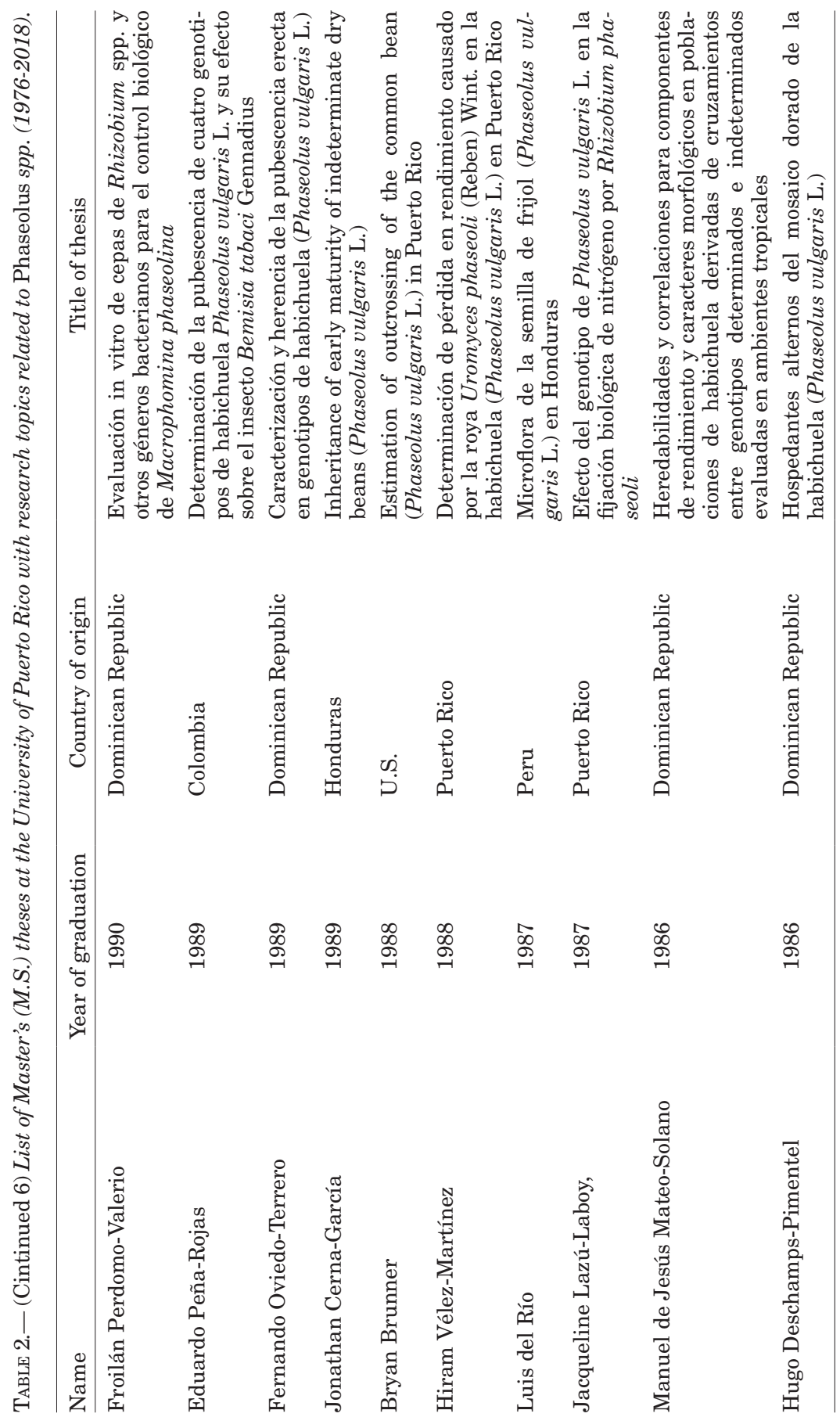


J. Agric. Univ. P.R. vol. 104, No. 1, 2020

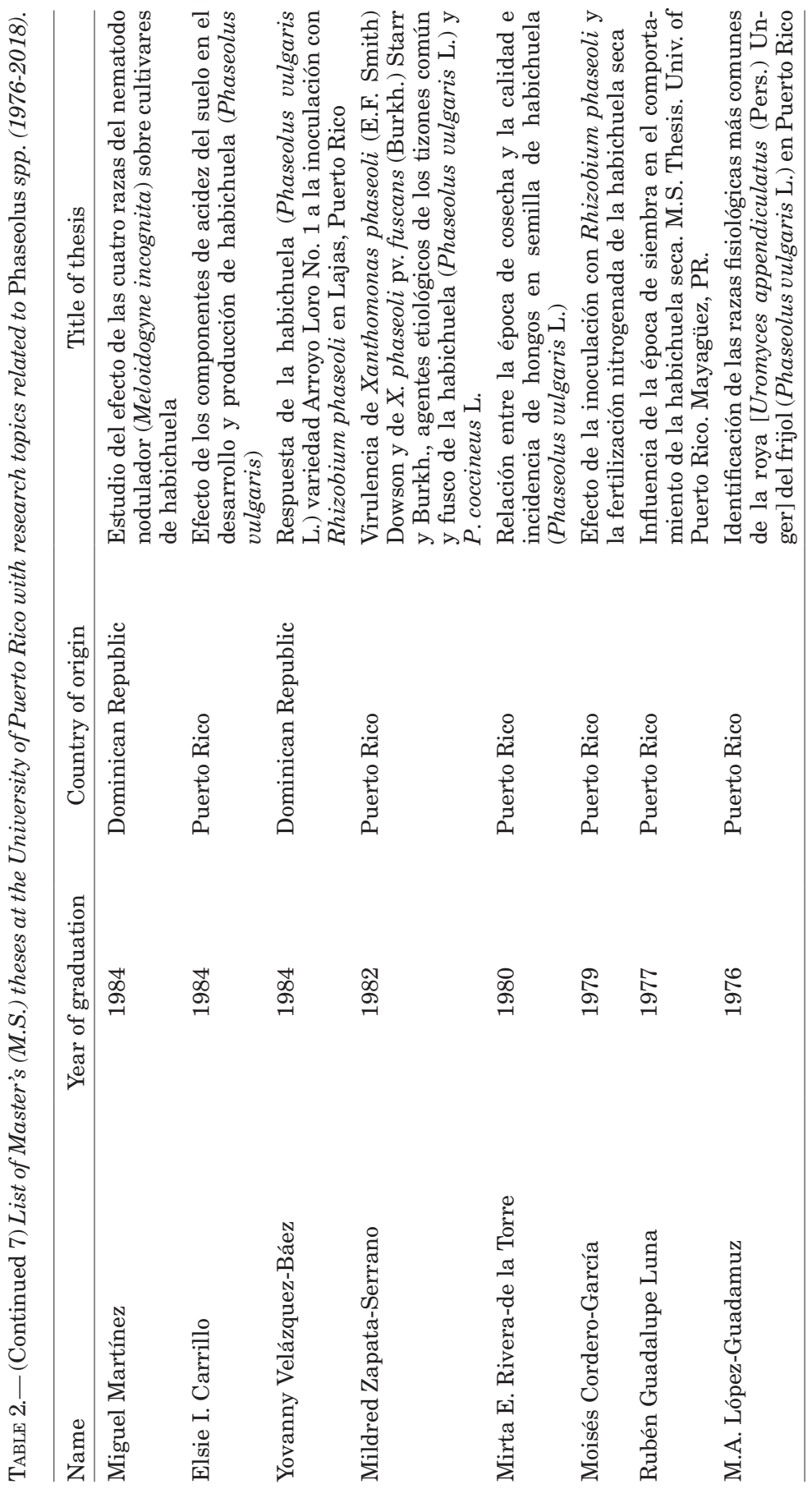




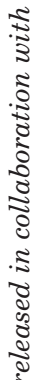

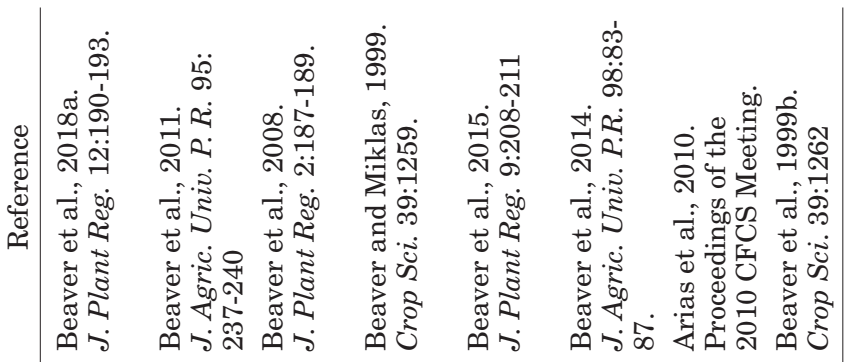

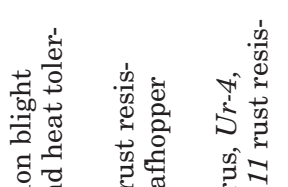

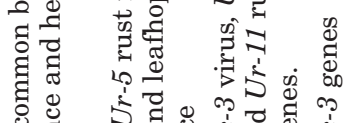

ठํ.

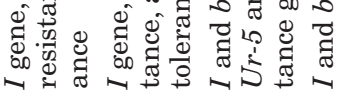

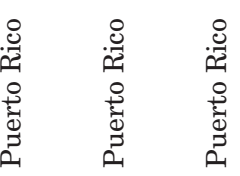

䆜

శా

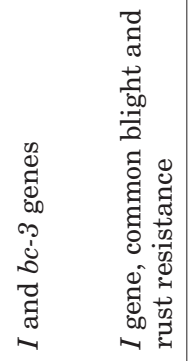

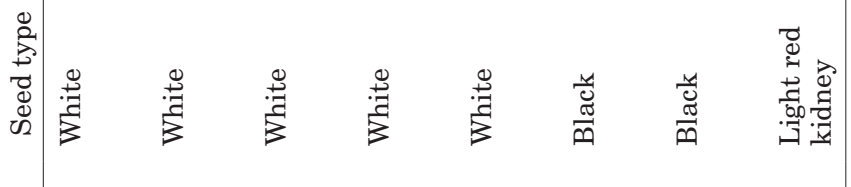

낭

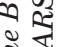

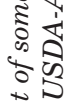

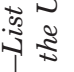

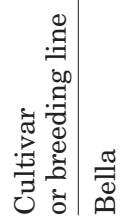

อ్ర

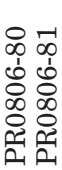

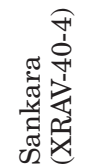

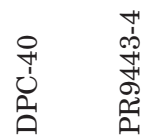


J. Agric. Univ. P.R. voL. 104, No. 1, 2020

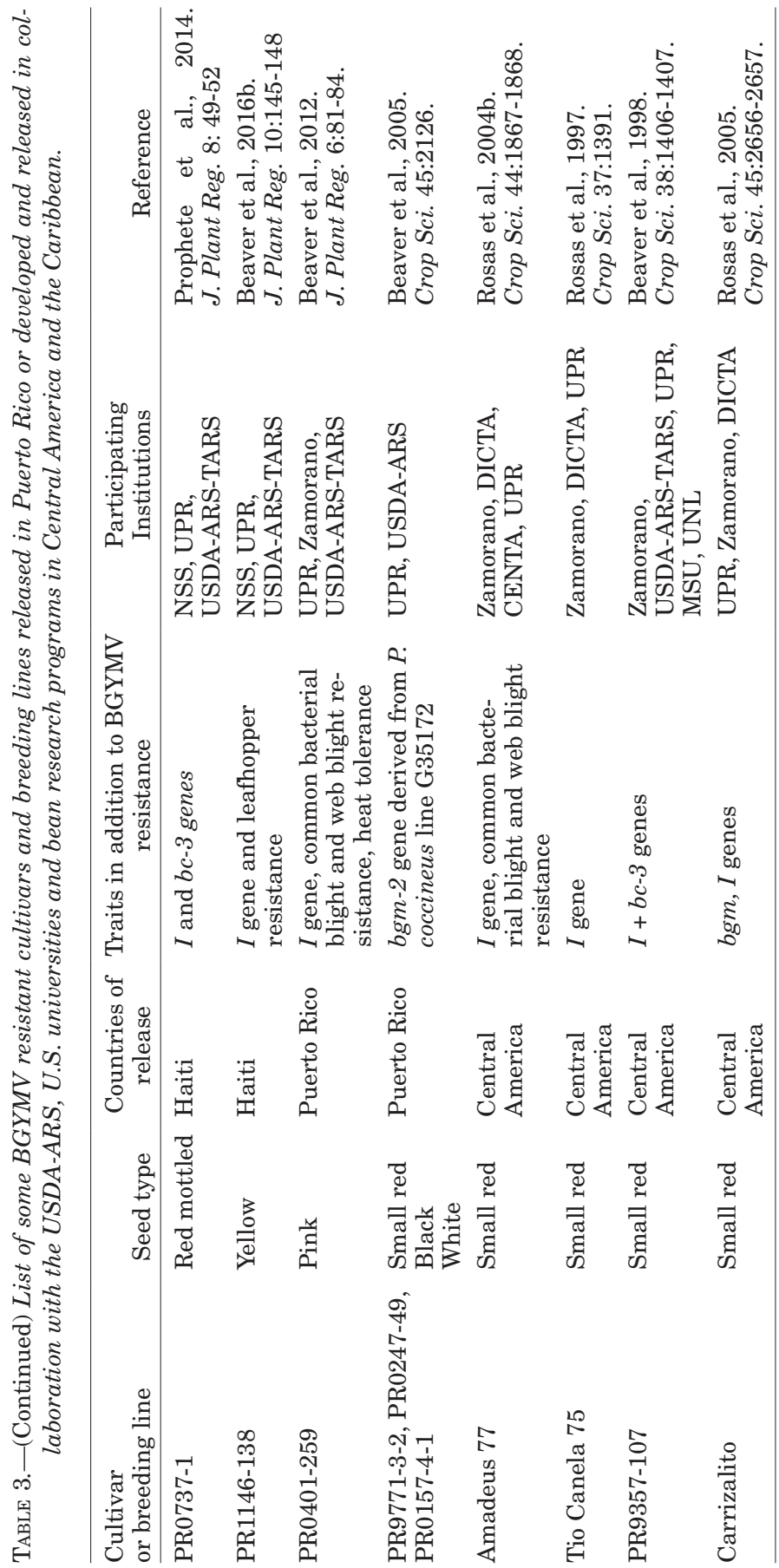




\section{Bean Golden Yellow Mosaic Virus}

Bean golden yellow mosaic virus (BGYMV) is a whitefly [Bemisia tabaci (Gennadius)] transmitted Begomovirus that represents a serious threat to dry and snap bean production in southern Florida, Mexico, Central America and the Caribbean (Singh and Schwartz, 2010; Blair et al., 1995). Bird and Maramorosch (1978) and Bird and Sánchez (1971) were pioneers in the study of viral diseases associated with whiteflies. Bird, a plant virologist of UPR AES, reported a whiteflytransmitted golden-yellow mosaic infecting lima beans in fields in northwestern and north-central Puerto Rico (Bird et al., 1972). Research followed using viruliferous whiteflies to infect common beans to determine the time needed to acquire, retain and transmit the virus (Bird et al., 1972, 1975), which based on physical properties was identified as BGYMV (Bird et al., 1977). Goodman et al. (1977) reported that infectivity of BGYMV was associated with a virus-like nucleoprotein particle. Bird et al. (1972) noted that BGYMV symptoms in Puerto Rico were very similar to the whitefly-transmitted bean golden mosaic virus (BGMV) infecting beans in Brazil. Not until nucleotide sequencing of the virus components was conducted, were they identified as distinct BGYMV and BGMV viruses (Faria et al., 1994; Maxwell et al., 1994).

Bird et al. (1972) also used viruliferous whiteflies to study host range in Puerto Rico and observed that only common bean and lima bean produced BGYMV symptoms. The host range was expanded to Macroptilium lathyroides by Rivera-Vargas et al. (2001) who observed symptoms in this weed species when they inoculated it with viruliferous whiteflies. Polymerase chain reaction (PCR) techniques, using primers from highly conserved regions of the viral genome, were used to confirm that $M$. lathyroides plants were infected with a geminivirus. Rivera-Vargas et al. (2007) studied the dissemination of BGYMV from infection foci in a bean field using statistical models. Martínez et al. (1991) did not find BGYMV to be transmitted in seed.

After several cycles of selection utilizing parents having different types of partial resistance to BGYMV, the International Center for Tropical Agriculture (CIAT) developed breeding lines that expressed high levels of resistance (Singh and Schwartz, 2010). A bean breeding line from CIAT, DOR 482, released in Honduras as 'Don Silvio' (Rosas et al., 2004a), was used as a parent in Puerto Rico to develop the BGYMV resistant white bean cultivar 'Morales' (Beaver and Miklas, 1999). Incrementally, other traits were added to cultivars harboring BGYMV resistance in subsequent releases of white beans for Puerto Rico (Table 2): 'Verano' added common bacterial blight resistance and greater tolerance to high temperature (Beaver et al., 2008); 'Beníquez' added BCMNV resistance with a more erect plant type (Beaver et al., 
2011); and 'Bella' added superior performance in low nitrogen soils (Beaver et al., 2018a).

Because white beans produced in Puerto Rico are used for greenshelled bean production, farmers generally purchase seed from the University of Puerto Rico Agricultural Experiment Station Seed Program. The natural incidence of BGYMV in Puerto Rico declined as the use of resistant cultivars became more widespread. The decline in the incidence of BGYMV also coincided with the release of exotic biological control agents (Encarsia spp. and Eretmocerus spp.) to control the silverleaf whitefly (Bemisia argentifolii Bellows \& Perring) (Pantoja et al., 2005). At present, it is difficult to find bean plants in Puerto Rico infected with BGYMV.

In the San Juan de la Maguana valley of the Dominican Republic, beans are not planted during the rainy months of September and October which reduces the number of viruliferous whiteflies. This is followed by a near-synchronous planting of beans in November (Coyne et al., 2003).

Blair et al. (1992) conducted field trials in the Dominican Republic, Puerto Rico and Honduras to study the inheritance of BGYMV resistance in recombinant inbred line (RIL) populations. The CIAT breeding lines A 429, DOR 364 and DOR 303 were used as the sources of resistance in the development of the RIL populations. These sources of resistance expressed a diversity of reactions to BGYMV. Blair et al. (1993b) noted BGYMV resistance reactions of RILs derived from crosses with A 429 were bimodal (qualitative) with approximately 50\% of the lines expressing resistance. A greenhouse screening technique developed by Adames-Mora et al. (1996) that allowed bean plants to be inoculated with a uniform number of viruliferous whiteflies facilitated subsequent inheritance studies of BGYMV resistance (Beaver et al., 1994). Blair and Beaver (1993a) used this new technique in greenhouse screening of $\mathrm{F}_{2}$ populations to discover that the non-chlorotic leaf reaction from A 429 was controlled by a single recessive gene. These results were confirmed by Vélez et al. (1998) from BGYMV evaluations of four generations of bean populations in greenhouses at the UPR, Mayagüez Campus. The gene symbol bgm- 1 was assigned to the recessive resistance gene derived from A 429. Urrea et al. (1996) used results from the greenhouse evaluations of these bean populations to develop the codominant RAPD marker R2 $2_{(570,530)}$ linked to bgm-1. The SCAR marker SR2 derived from the RAPD (Blair et al., 2007) has been widely used to select beans for BGYMV resistance. For example, marker-assisted selection (MAS) was used to introgress bgm-1 into indeterminate snap bean lines (Stavely et al., 2001) and to develop BGYMV resistant lines (Table 3) for Central America and the Caribbean (Beaver et al., 2008, 2011, 2018a). 
The moderately BGYMV resistant CIAT breeding line DOR 364, released in Central America as 'Dorado' (Rosas et al., 2004a), had delayed symptom expression (up to five days) compared with susceptible bean genotypes when inoculated in the greenhouse with viruliferous whiteflies (Adames-Mora et al., 1996). Miklas et al. (1996b, 2000) evaluated a RIL population derived from the cross 'DOR 364/XAN 176' in the field for reaction to BGYMV. They reported two QTL conditioning resistance and developed the SCAR marker SW12 (Singh et al., 2000) linked to the BGYMV resistance QTL on chromosome Pv04 with consistent expression across multiple field environments.

Blair et al. (1993a) reported that DOR 303 and the Dominican landrace 'Pompadour G' produced a dwarfing response when inoculated in the greenhouse with viruliferous whiteflies. However, leaves on infected plants showed little or no chlorosis. Results from the evaluation of $F_{2}$ populations derived from the cross 'DOR 303/T968' indicated that the BGYMV reaction was controlled by two genes; a dominant gene $(D w f)$ for the dwarfing response and a recessive gene (bgm-2) for the non-chlorotic response (Vélez et al., 1998). When inoculated with BGYMV, $F_{1}$ plants from the cross 'DOR 303/A 429' produced chlorotic plants demonstrating that $b g m-1$ and $b g m-2$ were not alleles. Moreover, DOR 303 did not have the $\mathrm{R} 2_{(570,530)}$ marker for the bgm-1 gene (Urrea et al., 1996). Subsequently, a BGYMV resistant light red kidney line, PR9443-4, derived from the cross 'T969-2/DOR 303' was released (Beaver et al., 1999b). The BGYMV resistance of this line was confirmed in field trials conducted in Puerto Rico, the Dominican Republic and Haiti as well as in greenhouse inoculations. Line PR9443-4 has a non-chlorotic leaf reaction (bgm-2) but does produce dwarf plants in the presence of BGYMV pressure. The bgm-2 gene represents an unexploited alternate source of resistance to BGYMV that should be used to broaden the resistance, primarily of the bgm-1 gene, currently deployed. The development of a molecular marker for bgm-2 would facilitate the use of this resistance gene.

Sister lines from the cross 'DOR 364/WBB-20-1//Don Silvio', selected for non-chlorotic leaf reaction (bgm-1) to BGYMV, were observed in the field to segregate for pod deformation under BGYMV pressure (MolinaCastañeda and Beaver, 1998). Segregation patterns in four generations and progeny tests supported the hypothesis that normal pod development in the presence of BGYMV is conferred by the single dominant gene Bgp (Acevedo et al., 2004). Lines selected only for bgm-1 tend to produce fewer and more deformed pods under BGMV pressure than lines selected for having both the bgm-1 and Bgp resistance genes. In the absence of a molecular marker for the Bgp gene, advanced generation breeding lines for Central America and the Caribbean have been 
screened in the field under BGYMV pressure to confirm resistance to pod deformation.

The scarlet runner bean ( $P$. coccineus L.) germplasm accession G35172 was reported by CIAT as resistant to BGYMV in Central America and the Caribbean (Beebe and Pastor-Corrales, 1991). The interspecific bean breeding line I9557-9 from a backcross population that used G35172 as a non-recurrent parent was selected by Phillip Miklas, USDA-ARS research geneticist, in the field at Isabela, Puerto Rico, for resistance to BGYMV. The $\mathrm{F}_{2: 3}$ lines from the cross 'Morales'/I9557-9 segregated for resistance to BGYMV which suggested that the BGYMV resistance in G35172 differed from the BGYMV resistance genes in 'Morales' (Osorno et al., 2007). Inheritance studies conducted in the greenhouse and field identified two genes from $P$. coccineus that confer resistance to BGYMV: a recessive gene ( $b g m-3)$ provides resistance to chlorosis and a dominant gene (Bgp-2) confers resistance to pod deformation (Osorno et al., 2007). Three BGYMV resistant bean breeding lines, PR9771-3-1 (small red), PR0247-49 (black) and PR0157-4-1 (white) were selected from these inheritance studies and released as improved germplasm (Beaver et al., 2005).

Morphological traits of beans may play a role in the behavior of the whitefly vector of BGYMV. Blair and Beaver (1993b) observed in field trials that the sweet potato whitefly [Bemisia tabaci (Genn.)] had a feeding preference and greater oviposition on the dense abaxial pubescence of Andean bean lines compared with the more glabrous leaves of beans of Mesoamerican origin. Peña et al. (1993) observed this same preference in greenhouse trials in which Andean beans with dense leaf pubescence had greater oviposition of whiteflies. Peña et al. (1993) did not find a relationship between bean leaf pubescence density on larval size and the time required by whiteflies to complete development. Interestingly, dense abaxial leaf pubescence is associated with lower levels of rust infection (Oviedo et al., 1990).

The UPR bean research program evaluated BGYMV reaction of transgenic bean lines developed at the University of Wisconsin having a gene for the BGYMV coat protein (Azzam et al., 1996). Unfortunately, the expression of the coat protein in the transgenic lines was insufficient to produce resistant reactions (Azzam et al., 1994).

The UPR and the ARS-TARS participated in USAID-funded projects that resulted in the release of several BGYMV resistant bean cultivars for Central America and the Caribbean (Table 3). The black bean cultivar 'DPC-40' was developed and released in the Dominican Republic in collaboration with the 'Instituto Dominicano de Investigaciones Agropecuarias y Forestales (IDIAF)'. The black bean cultivar 'Sankara', the red mottled bean PR0737-1 and the yellow bean PR1146-138 
were released in collaboration with the National Seed Service of the Ministry of Agriculture of the Republic of Haiti. Collaboration with the bean research program at EAP, led by Juan Carlos Rosas, has been particularly productive. Several BGYMV resistant small red and black bean cultivars jointly released with EAP have been widely adopted by farmers in Central America.

\section{Bean Common Mosaic Virus and Bean Common Mosaic Necrosis Virus}

Bean Common Mosaic Virus (BCMV) is caused by a seed-borne and aphid transmitted potyvirus that is an endemic bean disease in Central America and the Caribbean. The BCMV can cause significant losses to both the yield and quality of common beans. Landrace bean cultivars in the region are largely susceptible to BCMV. Since the release of 'Arroyo Loro' in 1990, all bean cultivars released in Puerto Rico have the $I$ gene that confers resistance to BCMV. Greenhouse inoculations with the NL-3 strain of Bean common mosaic necrosis virus (BCMNV) were used to detect lines with top necrosis symptoms. Most farmers in Puerto Rico produce green-shelled beans and generally do not save seed for planting. Therefore, the UPR-AES Seed Program at the Isabela substation has served as the principal source of seed of these BCMV resistant bean cultivars. Consequently, the incidence of BCMV is currently very low in Puerto Rico.

The BCMNV is caused by a different seed-borne and aphid transmitted potyvirus, but also has the potential to reduce the yield and quality of common beans. The increased incidence of BCMNV in the Dominican Republic, reported by Godoy de Lutz et al. (2004), pointed to the need to develop bean cultivars for Central America and the Caribbean with resistance to both BCMV and BCMNV (Kelly et al., 2003). In anticipation of this need, Miklas et al. (1997) improved upon the agronomic performance of Freytag's IM lines with the release of the TARS-VRs white germplasm lines with $I+b c-3$ genes which condition resistance to all strains of BCMV and BVMNV. Greenhouse screening with the NL-3 strain of BCMNV to detect $b c-3$ (no symptoms) and marker-assisted selection using SW13 SCAR marker (Melotto et al., 1996) to detect hypostatic $I$ gene were used to develop the most recent lines and cultivars (see Table 3 ) having complete resistance to BCMV and BCMNV. The RAPD markers (Miklas et al., 1996a, 2006) were replaced by the CAPS marker eIF4E (Naderpour et al., 2010) to indirectly select for and validate the presence of the $b c-3$ gene. The University of Puerto Rico participated in the release of the bruchid resistant dark red kidney bean breeding line AO-1012-29-3-3A that carries the $I$ and $b c-1^{2}$ genes that confer resistance to BCMV and BCMNV (Kusolwa et al., 2016). 


\section{Cucumber Mosaic Virus}

Bird et al. (1974) isolated, from the black bean cultivar 'La Vega', a virus capable of inciting mild mosaic and vein-banding symptoms on various hosts. Bean plants inoculated mechanically and with viruliferous aphids expressed moderate symptoms a few days after inoculation. Meiners et al. (1976) studied host range and used serology, physical properties and electron microscopy to confirm that CMV-PR was a strain of Cucumber Mosaic Virus. They also reported that CMV-PR was seed transmitted.

\section{Common Bacterial Blight}

Common bacterial blight caused by Xanthomonas axonopodis pv. phaseoli (Smith) Dye (Xap), previously Xanthomonas campestris (Xcp), is a seed-borne pathogen that can cause significant losses to the yield and quality of bean seed (Singh and Miklas, 2015). Research with common bacterial blight of beans began in Puerto Rico in the 1970s with support of a grant from USAID titled "Regional Food Legume Improvement" (Zapata and Beaver, 2002).

Vakili et al. (1974) collected 67 isolates from Puerto Rico and conducted cross inoculation studies to demonstrate that two pathogenic types of Xanthomonas can infect beans. One pathotype only infected common bean whereas the other pathotype infected both common beans and cowpeas. Zapata et al. (1994) isolated seed-borne bacteria from 86 lines in a field in Juana Díaz, Puerto Rico, that had high levels of common bacterial blight infection. Fifteen strains of Xcp, $23 \%$ of all bacterial strains isolated from the seed, were pathogenic to common bean.

Kaiser and Vakili (1978) noted that common blight lesions on leaves of common beans are often associated with damage caused by insect feeding. Xanthomonas isolates pathogenic to common beans were isolated from feces of Cerotoma ruficormus and Diaprepes abbreviatus that had fed on infected bean leaves. The bacteria survived up to 19 days in the bodies of living and dead insects. Feeding damage caused by both infested and non-infested insects enhanced common blight symptom development.

Zapata et al. (1985) reported that multiple methods were effective in screening bean leaves for reaction to common bacterial blight, including inoculation of trifoliate leaves at flowering using the multiple needles/cushion method or the spray infiltration method using carborundum or sterilized sand. Inoculating excised green pods nearing maturity using the needle-scratch method under controlled conditions was useful to screen pods for reaction to common bacterial blight. 
Beaver et al. (1992a) screened red mottled bean landraces from the Dominican Republic in the field for reaction to common bacterial blight over a two-year period. Indeterminate red mottled lines that had significantly lower levels of common bacterial blight damage were identified. Beaver et al. (1992b) reported that the common blight lesions of determinate red mottled landraces had little, or no chlorosis compared with the indeterminate red mottled lines evaluated in the trial.

A differential response of 'La Vega' black bean and the white bean line W-177 was observed when inoculated with six different isolates of Xcp from Puerto Rico (Zapata et al., 1985). This was the first of many subsequent studies led by plant pathologist Mildred Zapata which established the existence of physiological races of the common bacterial blight pathogen (Zapata and Vidaver, 1987; Zapata, 1996a, 1996b, 1997a, 1998; Zapata and Beaver, 2005; Zapata et al., 2012). Zapata (1989) also observed a differential reaction among tepary bean (Phaseolus acutifolius L.) genotypes when inoculated with different strains of $X c p$. The existence of physiological races, affirmed by the differential reactions of $X c p$ isolates collected in Costa Rica, Puerto Rico, the Dominican Republic and Haiti, was the prominent topic during the First International Workshop on Common Bacterial Blight held at the University of Puerto Rico in 1996 which was attended by scientists from the Americas, Europe and Africa with expertise in working with common bacterial blight (PROFRIJOL, 1996). Minimum standards to designate races of $X_{c p}$ (Coyne et al., 1996), a common set of bean differentials, and uniform inoculation and evaluation methods were proposed. Zapata (2006) eventually updated greenhouse screening procedures for uniform evaluation of bean leaves for response to Xcp. Zapata (1997b) suggested that a hypersensitive reaction of certain tepary bean genotypes to inoculation with the common blight pathogen may be useful for testing strains of Xanthomonas campestris pv. phaseoli.

The University of Puerto Rico and the USDA-ARS-TARS research programs have developed and released several bean germplasm lines and cultivars with enhanced levels of resistance to common bacterial blight (CBB). Vakili (1979) identified 11 breeding lines of $P$. coccineus as potential sources of resistance to common bacterial blight that were jointly released by the USDA-ARS and the University of Puerto Rico (Table 1). One of these CBB resistant breeding lines, $\mathrm{Pc}-\mathrm{H}-46-1 \mathrm{Bk}$ (a selection from PI 273667 from Ethiopia), was used by Mark Bassett at the University of Florida as a parent to develop an interspecific population. One of the progenies from this cross was the common bacterial blight resistant line XR-235-1-1 which was jointly released by the Universities of Florida and Puerto Rico and the USDA-ARS (Freytag et al., 1982). Overall results suggested that only a few major genes conferred 
common bacterial blight resistance in $P$. coccineus since the progeny of interspecific crosses between CBB resistant scarlet bean lines and susceptible common beans produced a high proportion of resistant lines.

The $P$. coccinues resistance sources were combined with common bean sources of resistance that included GN\#1 Sel. 27 by using a reciprocal backcross breeding method. Greenhouse screening at the University of Puerto Rico by Mildred Zapata and at Cornell University by Robert Wilkinson was followed by field evaluations for common blight in Puerto Rico during the summer when climatic conditions favored disease development. This collaboration led to the release of five (WBB-11, WBB-20-1, WBB-35, WBB-52, and WBB-II-56) common bean germplasm lines with high levels of resistance to common blight (Zapata et al., 2004, 1991). Miklas et al. (1994a, 1999) also developed and released five common bean germplasm lines (TARS VCI4B, and ICB-3, ICB-6, ICB-8 and ICB-10) with enhanced levels of common bacterial blight derived from $P$. coccineus, which traced back to $\mathrm{Pv}$ x Pc interspecific populations developed by Zapata. The common blight resistant pinto bean germplasm line TARS-PT03-1 (Smith et al., 2005) was derived from a cross with the interspecific ( $\mathrm{Pv} \times \mathrm{Pc})$ germplasm line TARS VCI-4B.

The pedigree of the white bean cultivar 'Verano' includes WBB-20-1, which derives a portion of its resistance from $P$. coccineus, and highly resistant bean germplasm VAX 6 line from CIAT, which derives its resistance from tepary bean (Singh et al., 2013; Beaver et al., 2008). Verano was used as a parent to develop the multiple disease resistant white bean 'Bella' (Beaver et al., 2018a).

In general, Andean germplasm and cultivars are highly susceptible to common bacterial blight. The light red kidney bean germplasm line PR9443-4 was derived from a cross between CIAT breeding line DOR 303 and T969-2, a kidney bean breeding line from Michigan State University. Line PR9443-4 was highly resistant to $\mathrm{CBB}$ when screened in the greenhouse with three different strains of Xcp and was used as a parent to develop the common bacterial blight resistant light red kidney bean cultivar 'Badillo' (Beaver et al., 2010, 1999c). 'Badillo' has the SAP6 QTL-linked marker for CBB resistance. Cranberry bean germplasms $08 \mathrm{SH}-840$ and CRX were developed by Tim Porch (ARS-TARS) from crossing USCR-CBB-20 (Miklas et al., 2011) with VAX 6 followed by four backcrosses to the recurrent parent, USCR-CBB-20, with phenotypic selection for $\mathrm{CBB}$ resistance conducted each $\mathrm{BC}_{\mathrm{n}} \mathrm{F}_{2}$ generation. These lines possess the SAP6 and SU91 QTL markers and were resistant to the Xcp ARX8AC strain in Idaho (Viteri et al., 2014) and Xcp strains 484a and 3353 in Puerto Rico. 
Bean germplasm lines selected for resistance to web blight such as the pink bean PR0401-259 and the black bean PR0650-31 often have resistance to common bacterial blight (Beaver et al., 2012). This may be the consequence of selecting beans having healthy leaf canopies under hot and humid conditions prevailing in Puerto Rico during the summer months. Both PR0401-259 and PR0650-31 derive their common blight resistance from VAX 6. Martínez-Figueroa (2017) selected bean breeding lines at Isabela, Puerto Rico, that combine resistance to both web blight and common bacterial blight.

The black bean germplasm line TARS-MST1 has resistance to common bacterial blight and root rot (Porch et al., 2012). Line TARS-MST1 derives its common blight resistance from VAX 6 and has the SAP6 and SU91 resistance QTL-linked markers. The small red bean germplasm line TARS-LFR1 was developed using recurrent selection and combines common bacterial blight resistance, root rot resistance and superior performance in low nitrogen soils (Porch et al., 2014a). The pedigree of TARS-LFR1 includes the common blight resistant lines VAX 1, VAX 2 and VAX 3 (Singh et al., 2013). The moderate level of common blight resistance of the small red germplasm line TARS-SR05 (Smith et al., 2007) was derived from XAN 176.

Varela et al. (1996) studied the inheritance of common bacterial blight resistance in the $\mathrm{F}_{3}, \mathrm{~F}_{4}$ and $\mathrm{F}_{5}$ generations in two Mesoamerican common bean populations (DOR 364/XAN 176 and DOR 364/WBB20-1). Significant differences among lines in common blight reaction were observed in all three generations. At least three replications were needed for sufficient precision to reliably identify resistance in the $\mathrm{F}_{3}$ lines. Heritability estimates of common blight resistance in leaves was intermediate to high $(\geq 0.6)$ in the $\mathrm{F}_{4}$ and $\mathrm{F}_{5}$ generations.

Miklas et al. (2000) used recombinant inbred lines from the 'DOR 364/XAN 176' population to identify QTLs associated with resistance to common bacterial blight strain 484a. The RAPD AP6 ${ }_{820}$ explained 60\% of the leaf reaction to common blight in the greenhouse and $10 \%$ of the leaf reaction in the field. The RAPD AP6 ${ }_{820}$ was converted to the SCAR marker SAP6 which was mapped on Pv10 (Miklas et al., 2003, 2000).

Zapata et al. (2011) identified a single dominant gene, Xap-1, that conferred resistance to Xap strain 3353. The SCAR SAP6 marker, located on $\mathrm{Pv10}$, was found to co-segregate with the resistant phenotype. Guachambala (2013) evaluated the common blight reactions of $\mathrm{F}_{2}$ plants and $\mathrm{F}_{2: 3}$ lines from a cross between the breeding line PR0313-58, which has the Xap-1 gene and moderate levels of resistance to common blight, and VAX 6 . The segregation pattern in this population suggested that two putative dominant genes conferred high levels of resistance to bacterial blight caused by Xap strain UPR 3353. 
The highest levels of resistance to common bacterial blight are found in tepary bean and most tepary beans have moderate to high levels of resistance (Vargas et al., 2014). Freytag (1989) reported three linked dominant genes conferring resistance to three $X c p$ strains in the tepary bean line TL-40. When inoculated with the $X c p$ strain $484 \mathrm{a}$, Urrea et al. (1999) found the common blight resistance of tepary bean lines Neb-T-6-s and PI 321637 to be controlled by a single dominant gene and the resistance of tepary line Neb T-8a-s was conferred by two complementary dominant genes. The first tepary germplasm developed and released through modern plant breeding methods, TARSTep 22, was developed for abiotic stress tolerance, seed quality and for resistance to common bacterial blight and rust (Porch et al., 2013a).

\section{Web blight}

Web blight produced by the mycelial infection of Thanatephorus $\mathrm{cu}$ cumeris [anamorph: Rhizoctonia solani $(R s)$ ] can reduce both the yield and quality of common bean seed in hot and humid regions of the tropics (Godoy de Lutz et al., 1996). Farmers in Puerto Rico describe beans damaged by web blight as being "stewed" ('sancochado'). Matz (1921) was the first researcher to isolate $R s$ from bean foliage in Puerto Rico. He noted that plants producing abundant foliage are more vulnerable to infection because the shade conserves humidity in the canopy and favors fungus growth.

Inoculation of beans in the field with a mycelial suspension of the pathogen has been used successfully to select bean breeding lines having enhanced levels of resistance to web blight (Beaver et al., 2012; Takegami et al., 2004). Because erect plant architecture and an open canopy can contribute to the avoidance of infection of web blight (Arnaud-Santana et al., 1992), droplet inoculation of leaflets (Polanco et al., 1996a; Montoya et al., 1997) and the detached-leaf technique (González-Martínez, 2004) have been employed to identify physiological resistance to this disease. Bautista-Pérez and Echávez-Badel (2000) reported positive and significant correlations between greenhouse and field readings for web blight reactions. Echávez-Badel et al. (2000) reported that dried beet (Beta vulgaris L.) seed colonized by $R$. solani could be stored for at least one year at $4^{\circ} \mathrm{C}$ in the dark without losing the viability or virulence of the fungus.

Echavéz-Badel et al. (2000) collected 13 isolates of Rhizoctonia solani from soil samples, infected seeds, hypocotyls, leaves and pods of common bean in Puerto Rico. Seven $R s$ isolates were classified as anastomosis group (AG) AG-4, and six were assigned to AG-1. Polanco et al. (1996b) reported that isolates of $R s$ from Isabela, Puerto Rico, belonged to anastomosis group AG-1. Inoculation using mycelial mats 
of Rs of anastomosis group AG-1, followed by frequent irrigation in the field, was useful for identifying lines moderately resistant to web blight compared to the susceptible local check 'Morales' (EchávezBadel et al., 2002). Furthermore, screening for web blight resistance requires knowledge of the virulence patterns of the Rs isolates in the target environment (Bautista-Pérez et al., 2000). Valentín-Torres et al. (2016) identified high variability in virulence patterns among different $R s$ isolates collected from bean leaves and roots in Puerto Rico. This research showed that $R s$ isolates from both roots and leaves can induce web blight symptoms when environmental conditions favor disease development. These results help to explain how web blight infection can occur in fields where beans have not been planted for several years.

Because the inheritance of web blight resistance has been found to be quantitative (Takegami et al., 2004; Montoya et al., 1997), recurrent selection was recommended to develop lines with greater levels of resistance to this disease (Aponte-Rivera, 2004; Beaver et al., 2001). The criteria for the evaluation using recurrent selection included low levels of leaf damage due to fungal and bacterial diseases, high seed yield, low percentage of damaged seed and the presence of genes for resistance to BGYMV and BCMV (Martínez-Figueroa, 2017). Because the web blight trials were planted at Isabela, Puerto Rico, under hot and humid conditions, indirect selection for greater tolerance to moderately high temperatures was also possible. The small red bean cultivar 'Amadeus 77' had a susceptible leaf reaction to web blight but lower levels of damaged seed when evaluated in the field (Rosas et al., 2018). Takegami et al. (2004) observed that different genes may control leaf reaction and seed damage caused by web blight. Releases in Puerto Rico of breeding lines having moderate levels of web blight resistance include the pink bean PR0401-259 and the black bean PR0650-31 (Beaver et al., 2012). Lines from the third cycle of recurrent selection conducted by EAP exhibited superior levels of resistance to web blight in field trials planted in Puerto Rico and Honduras (Rosas et al., 2018). The use of augmented designs involving spatial analysis can be useful in screening large numbers of bean lines for reaction to web blight (Rosas et al., 2019). Two resistant and two susceptible checks were randomized within sub-blocks containing 20 experimental units. Spatial analysis indicated that disease ratings (estimates of \% leaf area infected at 34 days after inoculation) from experimental units separated by distances $<10$ meters were correlated. Conversely, disease ratings from plots that were spaced $>$ $10 \mathrm{~m}$ apart could be considered independent for practical purposes. Thus, a spatial model estimated disease rating with greater precision than a traditional Incomplete Block Design. 
Because only moderate levels of resistance are found in common bean, scarlet runner bean and $P$. polyanthus germplasm were screened for web blight resistance (González Martínez, 2004). Using a detachedleaf inoculation technique, G35163 was identified as the $P$. coccineus accession most resistant to web blight by having less leaf damage and smaller mean lesion size than other accessions in the trial. An important criterion for evaluating the reaction to the web blight pathogen was the degree of penetration of the fungus into the leaf tissue. Recently, several RILs from a tepary bean population 'G40001/G40022' expressed moderate levels of resistance to natural infection of web blight in trials conducted at Isabela, Puerto Rico (unpublished).

Rusts

Bean rust caused by Uromyces appendiculatus (Pers.) Unger is an endemic disease of common bean in Puerto Rico. Rust can cause significant seed yield losses, especially in the tropics and sub-tropics where disease severity is often greater than in temperate bean production regions (Beaver et al., 2002; Mmbaga et al., 1996). The bean rust pathogen has highly variable virulence patterns which require constant monitoring for the presence of new races (Acevedo et al., 2013). A mobile nursery to monitor bean rust virulence patterns, developed at the University of Nebraska, was tested in Puerto Rico (Steadman et al., 2002a).

López-Guadamuz (1976) conducted a survey of bean rust in Puerto Rico and identified 12 different races. Stavely et al. (1989b) collected a rust isolate in 1984 at Isabela, Puerto Rico, that was virulent to the black bean line B-190 which has the $U r-5$ resistance gene. Vega et al. (2009) reported that a single pustule isolate collected from the white bean cultivar 'Verano' in Naranjito, Puerto Rico, was race 19:63. All Andean differentials were susceptible to this rust race whereas several Middle American resistance genes $\left(U r-3^{+}, U r-5\right.$ and $\left.U r-11\right)$ conferred resistance.

The First Bean Rust Workshop was held at Mayagüez, Puerto Rico, in 1983. A uniform set of differential bean lines was identified to characterize the virulence patterns of the bean rust pathogen. A standard 1 to 6 grading scale based primarily on pustule size for the evaluation of bean rust was also adopted at the workshop (Stavely et al., 1983). A new set of bean rust differentials was identified at the $3^{\text {rd }}$ Bean Rust Workshop held in Pietermaritzburg, South Africa, in 2002 (Steadman et al., 2002b). The new set of differentials provided a more balanced representation of Andean and Middle American sources of rust resistance in recognition of co-evolution of rust races and beans within gene pools. The use of a binary system to identify rust races was also proposed. 
Although the use of fungicides has been shown to be effective in controlling rust (Meléndez et al., 1986) and other fungal diseases of beans (Rodríguez and Meléndez, 1986), research in Puerto Rico has focused on host resistance. The black-seeded bean cultivar 'La Vega' (the bulk of individual plant selections from PI 287536) was released in Puerto Rico in 1973 (Table 1). It was reported to have small pustule size in the field resulting in "slow rusting". The white bean cultivar "Arroyo Loro', which combined rust resistance in Puerto Rico and the dominant $I$ gene for resistance to BCMV, was derived from the cross 'Bonita/ La Vega' (Beaver et al., 1990a). 'Arroyo Loro' was used as a parent to develop the white bean cultivar 'Morales' that combined resistance to BGYMV, BCMV and rust (Beaver et al., 1999a).

In 1976, the snap bean cultivar 'Palmarejo', a selection from PI 207139, was released in Puerto Rico (Table 1). The snap bean was highly resistant to rust races endemic in Puerto Rico. Researchers in Puerto Rico participated in the release of a pole snap bean cultivar 'Genuine' that combined resistance to BGYMV and rust (Stavely et al., 1996).

The black bean line Mexico 309 is a source of the Ur-5 rust resistance gene. B-190, a black bean released in Puerto Rico in 1979, was developed in Puerto Rico from a cross between Mexico 309 and 50600, a black bean line from Costa Rica. The Ur-5 rust resistance in B-190 was the first described cluster of $\mathrm{R}$ genes conditioning pathogen resistance in bean (Stavely, 1984). The Ur-5 cluster is mostly known as a gene block conditioning small pustule reactions (grade 3, slow rusting). Haley et al. (1993) identified a RAPD linked to Ur-5 from B-190 that was later converted to a SCAR marker by Melotto and Kelly (1998). The source of rust resistance in the development of the Great Northern bean lines BelNeb-RR-1 and -2 was B-190 (Stavely et al., 1989a). Rust resistant $\mathrm{F}_{1}$ plants from the cross 'B-190 x GN 1140' were subsequently backcrossed with GN 1140, Olathe, and Harris to develop these BelNeb lines.

Bokosi et al. (1996) used the bean rust isolates PR911-19a from Puerto Rico and USNP10-1 from the U.S. to study the inheritance of rust resistance in populations derived from the cross 'BelNeb-Rust Resistant (RR)-1/A-55'. The authors concluded that BelNeb-RR-1 had at least three resistance genes that should be useful to breed for resistance to these rust isolates. Pastor-Corrales (2003) reported that BelNeb-RR-1 and -2 combine the Ur-5, Ur- 6 and $U r-7$ rust resistance genes. Beaver et al. (1999b) used BelNeb-RR-1 as a source of rust resistance to develop the Mesoamerican pink bean cultivar 'Rosada Nativa'. This cultivar expressed resistance to rust in field trials conducted in Puerto Rico and the Dominican Republic. 
Mexico 309 was also used as a parent to develop the black bean breeding line 2B-5-1 (Table 1). Two rust resistant navy bean germplasm lines, L226-10 and L227-1, were cooperatively released by the UPR, the USDA-ARS and Michigan State University. The black bean parent 2B-5-1 was the source of rust resistance in these navy bean lines. Mexico 309, L226-10 and L227-1 were resistant to 12 races of rust when screened at Beltsville, Maryland (Freytag et al., 1985).

The light red kidney bean breeding line PR9443-4 combined resistance to BGYMV, common bacterial blight and rust (Beaver et al., 1999c). PR0443-4 was used as a parent to develop the light red kidney variety 'Badillo' (Beaver et al., 2010), which has resistance to endemic races of rust in Puerto Rico.

The white bean germplasm BelMiDak-RMR-10, which has the Ur-4 and $U r-11$ rust resistance genes (Pastor-Corrales, 2003), was used in Puerto Rico to develop the white bean germplasm lines PR0806-80 and PR0806-81 that combine resistances to BGYMV, BCMNV, BCMV and rust. Breeding lines developed by the USDA-ARS bean project at Beltsville, Maryland (Pastor-Corrales, 2003) have been used to introgress the $U r-11$ rust resistance gene into tropically adapted pinto beans. The USDA-ARS (TARS and Beltsville) collaborated with UPR to identify markers linked to the $U r$-11 gene derived from the tropical black bean PI 181996 (Johnson et al., 1995). The 'DOR 364/XAN 176' population revealed unique rust resistance genes, tentatively named Ur-Dorado-108 and -53, which were mapped respectively near Ur-5 and Ur-11 loci (Miklas et al., 2000, 2002).

The University Puerto Rico participated in the release of the red mottled cultivar 'PC-50', which expressed moderate levels of rust resistance in the Dominican Republic (Saladin et al., 2000). Bokosi (1996) found PC-50 to have the specific rust resistance gene Ur-9 and the Ur12 gene associated with adult plant resistance to rust. PC-50 and other red mottled bean landraces also have dense abaxial leaf pubescence (Oviedo et al., 1990), which was reported by Shaik (1985) to be associated with rust resistance. Zaiter et al. (1990) reported that presence and absence of pubescence was simply inherited whereas abaxial leaf pubescence density was a quantitatively inherited trait.

The rust resistant pinto bean germplasm TARS VCI-4B was derived from an interspecific cross between Phaseolus vulgaris and $P$. coccineus (Miklas et al., 1994a). Rust resistant tepary bean lines were also identified in Puerto Rico (Miklas et al., 1994b). Miklas and Stavely (1998) identified seven cultivated tepary genotypes with broad resistance to eight rust races. Results from inheritance and allelism tests suggested that a single locus exhibiting incomplete dominance conferred resistance 
to these rust races. One of these tepary bean accessions was later used to develop rust resistant TARS-Tep22 (Porch et al., 2013a).

The first report of the New World soybean rust, caused by Phakopsora meibomiae, was made in Puerto Rico by Vakili and Bromfield in 1976. The New World soybean rust infected common bean, scarlet runner bean and soybean at Adjuntas, Puerto Rico (Vakili and Bromfield, 1976). Recent studies confirmed lima beans were susceptible to $P$. meibomiae, which adds to the list another Phaseolus species facilitating the spread of the New World soybean rust (Vega and Estévez de Jensen, 2010). Common bean was reported to be more susceptible to $P$. meibomiae isolates from Brazil and Puerto Rico than to an Asian soybean rust ( $P$. pachyrhizi) isolate from Taiwan (Miles et al., 2007). Estévez de Jensen et al. (2013) confirmed the presence of Asian soybean rust, although this rust has not been found infecting common beans in Puerto Rico.

\section{Stem rot and Root Rot}

Root rot and stem rot are worldwide constraints on bean production (Miklas et al., 2006). Porch et al. (2014a) noted that greater severity of root and stem rots is often associated with abiotic stresses such as extreme temperature, drought, excess moisture, compacted soil, low soil $\mathrm{pH}$ or poor soil fertility. Cropping systems that rotate beans generally have fewer problems with soil-borne diseases (Abawi and Widmer, 2000).

A root rot nursery was established by Vakili in 1971 at the USDA-ARS research farm in Isabela, Puerto Rico. This nursery has been planted almost continuously in beans to increase root and stem rot pathogen populations. Results from surveys conducted in the nursery from 2009 to 2012 found the predominant soil-borne pathogens to be Fusarium solani, Macrophomina phaseolina, Sclerotium rolfsii and Phythium spp. (Porch et al., 2014b). Because the field has not been fertilized, the nursery has been used by the USDA-ARS bean breeding program to screen bean lines for resistance to both root rot and stem rot and for adaptation to low soil fertility. Results from 16 samples of common bean tissue collected from the nursery found $\mathrm{N}, \mathrm{P}, \mathrm{K}$ and $\mathrm{Mg}$ to be below the sufficiency range needed for normal development of bean plants (Porch et al., 2014b). Results from the nursery have been used to support the release of several improved bean breeding lines (TARSLFR1, TARS-MST1, and SB-DT1) that are more tolerant to root rot and low soil fertility (Porch et al., 2014a, 2012).

Ashy stem blight caused by Macrophomina phaseolina $(M p h)$ is an endemic disease in the dry and warm areas of Puerto Rico. Damage caused by Macrophomina phaseolina can range from damping-off at 
emergence to stem blight and root rot near maturity (Miklas et al., 1998). Beaver et al. (1990b) noted that field screening for ashy stem blight resistance is difficult because the distribution and severity of infection in the field is often uneven. In addition, field screening for resistance requires the entire growing season because the symptoms of ashy stem blight tend to be more severe near senescence.

Different inoculation methods have been assessed including the band-aid, toothpick, mycelial plug, inoculated rice and the conidia suspension method (Echávez-Badel and Beaver, 1987a, 1987b). In the Dominican Republic, Beaver et al. (1990) compared the effectiveness of field screening for ashy stem blight using seed soaked in microsclerotia suspension versus stem inoculations performed 15 days after emergence. The stem base was rubbed with cheesecloth that had been soaked in a suspension containing approximately 1,000 microsclerotia per milliliter and $10 \mathrm{~g} / \mathrm{L}$ of carborundum. Porch et al. (2014c), using the "band-aid" inoculation method, observed significant dry bean genotype x $M p h$ isolate interactions for lesion length and disease severity ratings. The isolate $(M p h$-JD) from Juana Díaz (with a hot dry climate favorable for Mph epidemics) was the most virulent when compared to the isolates from Isabela and Aguadilla. An expanded study of ten Puerto Rico Mph isolates x 120 dry bean genotypes in the BASE (Bean Adaptation to Stress Environments) trial confirmed differential virulence among isolates. Once again, the most virulent isolate $M p h$-JD2, which induced susceptible reactions in all 120 genotypes, was collected from Juana Díaz (Estévez de Jensen et al., 2017). The germplasm lines PR1147-3, TARS-LFR1 and TARS-MST1 from Puerto Rico, and Mph resistant CIAT line BAT 477, had the best intermediate (less susceptible) reactions to $M p h$-JD2.

The Andean Diversity Panel (ADP) developed by a team of USDAARS researchers to enhance genetic study and breeding improvements of large-seed sized beans was compiled and increased in Puerto Rico in 2011-2012 (Cichy et al., 2015). The panel database is maintained by Porch at http://arsftfbean.uprm.edu/bean/. The response of the ADP to different isolates of $M p h$ was determined. Variable disease severity reactions, morphological diversity and high levels of sequence similarity in the ITS region between the isolates from Puerto Rico and isolates from other regions were observed (Porch et al., 2014c). A Genome Wide Association Study (GWAS) of the BASE 120 trial conducted under heat and drought stress in Juana Díaz, Puerto Rico, identified a genomic region on Pv04 associated with resistant ashy stem blight field scores (Oladzad et al., 2019)

Miklas et al. (1998) conducted field trials at Juana Díaz, Puerto Rico, to study the inheritance of resistance to $M p h$ in the 'DOR 364/ 
XAN 176' RIL population. Narrow sense heritability estimates for ashy stem blight resistance were intermediate $( \pm 0.5)$. Five QTL, derived from the resistant line XAN 176, explained a significant portion of the phenotypic variation for disease score.

Viteri and Linares (2019) investigated the inheritance of Andean bean cultivars 'Badillo' and 'PC-50' and breeding line A-195, which expressed less severe symptoms to two $M p h$ isolates from Puerto Rico at vegetative and reproductive stages using a cut stem inoculation method (Viteri and Linares, 2017). Resistance to $M p h$ isolate PRI16 of 'Badillo' was conferred by a single recessive gene, whereas the resistance of 'PC-50' was controlled by two independent complementary recessive genes. Segregation patterns between lines derived from the cross 'A 195 x PC-50' suggested that a single dominant gene conferred resistance to $M p h$ isolate PRI16.

Perdomo et al. (1995) conducted in vitro evaluations of 64 strains of Rhizobium and seven strains of rhizosphere bacteria to measure their antibiotic activity against $M p h$. The UPR 5C isolate of Burkholderia cepacia (previously known as Pseudomonas cepacia) strongly inhibited the growth of $M p h$ using the streak-plate method and yeast extract/ mannitol growth media for the bioassay. Sánchez et al. (1994b) demonstrated the UPR 5C isolate successfully colonized the bean root after inoculation of the seed. Results from greenhouse trials found that inoculation of seed with UPR 5C strain reduced the severity of ashy stem blight by $71 \%$ and was compatible with inoculation using Rhizobium phaseoli strain CIAT 632 (Sánchez et al., 1994a).

\section{Leafhoppers}

The 1902 USDA Agricultural Research Station report noted that leafhoppers (Empoasca spp.) were the most serious pest in bean trials conducted in Puerto Rico. Cruz (1975) stated that leafhoppers are one of the most limiting factors for bean production in Puerto Rico. He reported that chemical control was effective in reducing leafhopper populations and resulted in greater yield of snap beans. Cruz et al. (1981) noted that the use of silver-plated plastic mulch and sugarcane straw mulch resulted in fewer leafhopper nymphs on beans planted at Isabela, Puerto Rico.

Predicted climatic changes in the Caribbean including warmer and drier weather patterns would favor leafhopper populations. Plant breeders in Puerto Rico have made progress in developing bean germplasm and cultivars through indirect selection for leafhopper resistance at the Isabela Substation. Locally released cultivars such as 'Morales' show less leafhopper damage. The yellow bean germplasm line PR1146-138 was identified in Haiti to have good levels of resistance 
to leafhoppers (Beaver et al., 2016b). The pinto bean germplasm line TARS-LH1 was screened in Puerto Rico for resistance to leafhoppers (Porch et al., 2020). Trials in Puerto Rico and Haiti were used to select tepary bean breeding lines resistant to leafhoppers.

Brisco et al. (2014) screened at Isabela, Puerto Rico, and Michigan, an inbred backcross line population from the cross 'Matterhorn*2/EMP 507 ' for reaction to $E$. kraemeri and E. fabae. Results from these trials were used to identify QTL associated with resistance to this pest, and lines resistant to both species. A major QTL cluster associated with multiple resistance traits and closely linked to the $\mathrm{P}$ color gene was detected for both leafhopper species in multiple seasons on Pv07.

\section{Other bean pests}

Martínez (1984) studied the response of common bean cultivars to four races $(1,2,3,4)$ of the root knot nematode (Meloidogyne incognita). The snap bean line B4175 (Wyatt et al., 1980) expressed moderate resistance to all races with no significant reduction in shoot or root weight. The white bean line $\mathrm{W}-117$ was only resistant to races 3 and 4. Vicente et al. (1987) studied the influence of temperature and soils from Isabela, Lajas, and Santa Isabel, Puerto Rico, on the histopathology of Meloidogyne incognita on snap beans. Greater nematode numbers in roots were observed as temperature increased from 15 to $25^{\circ} \mathrm{C}$. The Fraternidad silty clay from Lajas was most favorable for root knot nematode development.

Smith (2002) conducted a greenhouse study to screen three resistant and three non-resistant common bean lines for reaction to the race 2 of the soybean cyst nematode (Heterodera glycines) from Isabela, Puerto Rico, using three infestation densities (0;4,000; and 8,000 eggs and juveniles per pot). The results suggested that this race of soybean cyst nematode would not affect common bean yield.

Cruz and Cardona (1981) identified the common bean weevil (Acanthoscelides obtectus) as a serious pest of stored dry beans in Puerto Rico. The UPR bean breeding program collaborated with researchers from Oregon State University, Sokoine University in Tanzania and the USDA-ARS that led to the release of an Andean red bean germplasm line that combines resistance to the common bean weevil and the $I$ and $b c-1^{2}$ genes that confer resistance to BCMV and BCMNV (Kusolwa et al., 2016). Mesoamerican black bean breeding lines have also been developed that combine common bean weevil resistance with resistance to BGYMV, BCMV and BCMNV (Beaver et al., 2016a). Mateo (2016) studied segregation patterns of five $\mathrm{F}_{4}$ populations derived from parents resistant and susceptible to weevil damage. The low frequency of $\mathrm{F}_{4}$ lines with high levels of resistance to weevils suggested that the 
complex APA locus is not the only factor associated with resistance to the common bean weevil. This information was confirmed by Kamfwa et al. (2018) who identified three QTL for resistance to A. obtectus on $\mathrm{Pv} 04$ and on Pv06. One of the QTL on Pv04 was previously reported as the APA resistance locus while the other two QTL were new.

Wolcott (1933) and Leonard and Mills (1931) reported that pod borer damage was a major factor limiting lima bean production in Puerto Rico. Scott (1940) reported that three species of pod borers, namely the legume pod borer Maruca testulalis (Geyer), the lima bean pod borer Etiella zinckenella (Treitschke) and Fundella cistipennis (Dyar), were found infesting wild and cultivated grain legumes throughout Puerto Rico. Lima bean cultivars were screened for pod borer damage in a replicated trial planted in 1936 at Mayagüez, Puerto Rico. The smallseeded pole lima bean cultivar 'Carolina' was reported to be highly resistant to pod borer damage.

\section{Heat and drought stress}

Due to the lowland tropical location of bean production in Puerto Rico, high ambient temperature stress and drought are important constraints (de Ron et al., 2019). A study at the University of Puerto Rico projecting future climate change effects on common bean production using Bayesian analysis of a linear mixed model indicated that the predicted increase in temperature will have a negative impact on bean yields in most countries by 2030 (Palomino, 2012). Bean planting seasons in Puerto Rico are historically delineated by abiotic constraints. High temperature and problems associated with excessive rainfall can reduce bean seed yield and quality during the hot summer bimodal rainy season (May to October). The shorter, cooler dry season (December to March) is a more favorable planting season for bean production in Puerto Rico if the farmer has access to irrigation. Compared with seed from beans planted in Honduras in October, del Rio et al. (1991) found that bean seed planted in June had lower germination, less vigor and higher levels of fungal infection.

Drought (terminal and intermittent) is a continuous threat to bean production on small-scale farms in Central America and the Caribbean. Key traits associated with drought tolerance (Ramírez-B. et al., 2008; Ramírez-Builes et al., 2011) have been studied in Puerto Rico. Earliness in combination with selection for harvest index improved drought tolerance (Beaver and Rosas, 1998). Resistance to ashy stem blight can improve tolerance to drought stress (Miklas et al., 1998). Genetics of drought tolerance evaluated over multiple years (Linares et al., 2012, 2014) in Puerto Rico and Nebraska revealed QTL for yield components and leaf temperature. Combined tolerance to heat and drought stress 
is important given these constraints often overlap in the lowland tropics (Beaver et al., 2003).

Advances have been made in selection indices for heat tolerance (Porch, 2006), in the elucidation of the genetics of heat tolerance (Román-Avilés and Beaver, 2001, 2003) and in the development of improved Andean and Middle American germplasm for abiotic stress tolerance. Early releases (Table 1) with adaptation to high temperature stress include 'Congo Rico', a selection from a tropical cranberry bean from the Congo; 'Palmarejo' red mottled; and 'Rosada Nativa> (Beaver et al., 1999a) that was released in Puerto Rico and the Dominican Republic. Line 'IJR' (Indeterminate Jamaica Red = PI 163122) was first recognized as being heat tolerant in Puerto Rico (Baiges et al., 1996). Recent lines, purposely bred for stable yield response across varied high day and night temperature environments, include: TARS-HT1 and -HT2 kidneys (Porch et al., 2010), TARS-MST1 black (Porch et al., 2012), 'Verano' (Beaver et al., 2008), 'Bella' (Beaver et al., 2018a), and snap beans (Wasonga et al., 2010). However, many beans bred and released in Puerto Rico for other traits (described above) exhibit tolerance to high temperatures because it was a common stress in the selection environments: L-226-10 and L-227-1 (Freytag et al., 1985), 'Verano' (Beaver et al., 2008), and 'Badillo' (Beaver et al., 2010). A GWAS of the BASE 120 trial conducted under heat and drought stress in Juana Díaz, Puerto Rico, identified a genomic region on $\mathrm{Pv} 03$ associated with seed yield (Oladzad et al., 2019).

A shuttle breeding program for drought was initiated between the University of Nebraska and ARS-TARS in 2005, resulting in the multistate Dry Bean Drought Nursery (DBDN) and in the development of germplasm. Black bean germplasm SB-DT1 released with tolerance to root rot and drought (Porch et al., 2012) is a product of this program. This shuttle breeding program (Urrea and Porch, 2010) has also led to the introduction of exotic tropical germplasm for broadening the genetic base of elite U.S. germplasm and introducing new traits related to drought tolerance (Traub et al., 2018).

\section{Agronomic Practices and Mineral Nutrition}

In 1906, Hendricksen published a bulletin entitled 'Vegetable growing in Puerto Rico'. The publication noted that, although there was a large amount of importation from Europe, beans were produced in Puerto Rico and local cultivars were considered well adapted for dry bean production. Native white bean cultivars were considered promising although more testing was recommended. Fungal diseases were considered the biggest challenge for bean production. 
Most beans currently produced in Puerto Rico are harvested at the green-shelled stage of development. Green-shelled beans are produced in monoculture and intercropped with plantains and other crops having longer growing cycles. Beans and other food crops were intercropped with sugarcane (Saccharum officinarum) to increase the supply of locally produced food during World War II. Lugo-López et al. (1953) observed that bean/sugarcane intercropping had no significant effect on yield of beans or on the ratoon crop of sugarcane. Compared with sugarcane monoculture and intercropping with other food crops, the bean/ sugarcane intercrop produced the greatest mean profit per acre. Liu et al. (1999, 1997) studied the feasibility of intercropping beans with plantains (M. acuminata $\times$ M. balbisiana) at the Corozal Substation. Plantain yield was not affected by the intercrop of green-shelled beans. Compared with a plantain monoculture, intercropping beans produced $\$ 4,894 /$ ha greater net income. Lui et al. (1999) conducted a similar study in Aguas Buenas, Puerto Rico, in which bananas (M. acuminata) and green-shelled beans were intercropped. Two intercroppings of the bean cultivar 'Arroyo Loro' planted in November produced the highest combined net income $(\$ 6,433 / \mathrm{ha})$.

The performance of pole snap beans was tested in trials planted at Isabela in April 1959 (Ramírez and Abrams, 1960). The pole bean cultivars 'Florigreen' and 'Blue Lake 231' produced whole pod yields $>15$ t/ha. 'Florigreen' was the highest yielding pole snap bean in pole bean trials conducted at the Gurabo Substation (Ramírez and Vélez-Santiago, 1962). 'Florigreen' was resistant to BCMV and rust, which were considered to be serious bean diseases. At Adjuntas, Mangual-Crespo and Torres (1979) evaluated the performance of pole bean cultivars in within-row plant spacings ranging from 8 to $30 \mathrm{~cm}$ with a spacing of $90 \mathrm{~cm}$ between rows. The pole bean lines planted with $8 \mathrm{~cm}$ within-row spacing produced a mean yield of $11.6 \mathrm{t} / \mathrm{ha}$.

Mangual-Crespo (1975) reported that the determinate cultivar 'Contender' produced the highest yield of marketable snap beans when planted at the Isabela Substation from December to March. The determinate snap bean cultivar 'Harvester' produced approximately $90 \%$ of No. 1 grade beans at the Isabela Substation in trials planted in September, December and March (Rodríguez et al., 1979). Mangual-Crespo (1977) compared single and multiple harvests of determinate snap beans planted at the Isabela Substation. Because no significant differences were found between harvest systems, the author recommended a single harvest to lower production costs. Preliminary results from a trial conducted at the Fortuna Substation found no significant difference in yields of snap beans harvested by hand compared to the use of a mechanical harvester (Mangual-Crespo and González, 1981). Results 
from field trials conducted at the Lajas Substation demonstrated that determinate snap beans can be produced successfully in Puerto Rico under an organic management system (Brunner et al., 2014).

Badillo-Feliciano et al. (1985) noted that harvesting beans at physiological maturity, which is 15 days earlier than when 'dry' beans are harvested, has several advantages. Earlier harvests reduce the risk of crop loss due to unfavorable weather and late season diseases. Yields of whole pods harvested at physiological maturity were at least three times the yield of dry beans at both the Isabela and Fortuna Substations. Lastly, green-shelled beans are more profitable because they command almost twice the market value as dry beans.

Research on when to initiate harvest was conducted to optimize yield and quality of green-shelled beans. Cerna and Beaver (1989) studied seed weight accumulation patterns of two Mesoamerican bean lines over two growing seasons. Physiological maturity (maximum seed weight accumulation) occurred when approximately two green pods remained at the top of the indeterminate bean plants. This was proposed as a convenient visual marker for physiological maturity of small-seeded indeterminate beans. Román-Hernández and Beaver (1997) concluded that appearance of the first dry pod was a useful morphological marker to begin the harvest of green-shelled beans. Initiating harvest at this stage of development represented a compromise between yield potential and the quality of green-shelled beans. Further research showed that harvest of green-shelled beans could be delayed as much as one week after the appearance of the first brown pod without losing green-shell bean yield (Beaver, 2000).

Beaver and Román-Hernandez (1994) evaluated the performance of white bean lines in field trials planted at the Isabela and Fortuna Substations at different dates over a four-year period. Although greenshelled beans can be produced in Puerto Rico over a wide range of planting dates, the October to December planting dates produced the highest yields. Green-shelled bean yields were lower and more variable when beans were planted during the warm and humid summer months. However, higher prices help to offset the greater risk associated with green-shelled bean production during the summer. Results from this study led to the development of the white bean cultivar 'Verano' that was selected for better adaptation to hot and humid conditions (Beaver et al., 2008). Beaver (2000) noted that DOR 364 produced greater yield than 'Arroyo Loro' by partitioning a greater portion of whole pod weight into green-shelled bean yield which suggested a trait for selecting beans with improved green-shelled bean production.

Dry bean production has potential in Puerto Rico as a crop planted in rotation with basic grain and forage crops such as maize (Zea mays L.), 
sorghum [Sorghum bicolor (L.) Moench], pigeon peas [Cajanus cajan (L.) Millsp.] and soybeans [Glycine $\max$ (L.) Merr.]. Commercially acceptable seed yields are achieved when adapted bean cultivars are planted using recommended production practices. The UPR AES has developed a Technology Package that describes the recommended production practices for dry and green-shelled bean production in Puerto Rico.

The production of dry bean in Puerto Rico is recommended for the drier and cooler months when disease pressure is lower and higher quality seed can be produced. Guadalupe (1977) evaluated the performance of dry bean lines planted over four planting dates at the Lajas Substation. The December planting produced the highest seed yield. The lowest seed yields were obtained from the September planting date although the percentage of protein of the seed harvested from the September planting date was higher than the other seasons. Lozano et al. (1983) evaluated the effect of planting date on the seed yield of dry beans planted in Orocovis and Gurabo, Puerto Rico. Seed yields at Orocovis were greatest for the March and May planting dates, whereas Gurabo had the highest yields when planted in January, March and November. Lower seed yields at Gurabo for the May, July and September planting dates were attributed to higher temperatures and excessive rainfall.

Agronomic practices can have a significant effect on the performance of green-shelled and dry beans. González-Ríos and Riollano (1951) compared the performance of white bean landraces in 30- and $60-\mathrm{cm}$ row widths and obtained higher yields in the $30-\mathrm{cm}$ row width. Badillo et al. (1978) evaluated the performance of a determinate light red kidney bean and an indeterminate white bean when planted at the Isabela Substation at spacings of 30,45 and $60 \mathrm{~cm}$ between rows and corresponding plant populations of 444,000;296,000; and 222,000 plants per hectare. No significant differences in seed yield were observed between the row spacings. Beaver et al. (1988) evaluated the performance of bean lines at Isabela and Juana Díaz, Puerto Rico, when planted at different between and within row spacings. The highest seed yield was obtained at the Fortuna Substation when beans were planted in $0.5-\mathrm{m}$ row widths and a within row seeding rate of 19.8 seeds per meter. Seed yield increased in a linear fashion as within row seeding rates increased from 6.6 to 19.8 seeds per meter.

Weed control is one of the greatest challenges facing bean producers in the humid tropics. Semidey et al. (2007) demonstrated in field trials conducted at Isabela and Juana Díaz, Puerto Rico, that the sequential use of pre and post emergent herbicides in combination with mechanical control can effectively control weed populations and can result in significant increases in bean seed yield. 
Lugo-Mercado et al. (1984) studied the effect of tillage on the performance of beans and other crops at the Fortuna Substation in Juana Díaz, Puerto Rico. They found no significant differences in bean seed yield in tilled and non-tilled plots. Vicente-Chandler et al. (1966) also demonstrated that beans planted in trials on hillsides in Adjuntas and Orocovis, Puerto Rico, produced equivalent yields using conventional and minimum tillage.

Soil acidity and low nitrogen $(\mathrm{N})$ and low phosphorus $(\mathrm{P})$ availability are important edaphic constraints for bean production in Puerto Rico. Lugo-López (1977) evaluated the response of the white bean cultivar 'Bonita' to varying levels of $\mathrm{N}$ in field trials planted at the Isabela Substation. Using the Capó fertilizer-yield equation, they found that $80 \mathrm{~kg} / \mathrm{ha}$ of $\mathrm{N}$ produced $>95 \%$ of maximum seed yield $(1,461 \mathrm{~kg} / \mathrm{ha})$. Del Valle et al. (1981) reported that 'Bonita' responded to banded P fertilizer, whereas there was no response to broadcast residual $\mathrm{P}$ in field trials planted in Cidra, Puerto Rico.

Dorcinvil et al. (2010) conducted field trials at the Isabela Substation and identified the black bean line PR0443-151 and the small red line VAX 3 from CIAT to produce among the highest seed yields in both low N and low P soil treatments. Line PR0443-151 combined N use efficiency ( $\mathrm{kg}$ of seed yield/kg of $\mathrm{N}$ in the soil) and agronomic efficiency (kg of seed yield/kg of $\mathrm{N}$ applied) to $\mathrm{N}$ fertilization. Using a commercial peat inoculant, Ramírez (2009) reported that VAX 3 and PR0443-151 were among the most responsive bean lines to seed inoculation with Rhizobium spp.

Ruiz-Quiles (2010) evaluated the performance of Mesoamerican bean lines in the $\mathrm{F}_{3}, \mathrm{~F}_{4}$ and $\mathrm{F}_{5}$ generations at the Isabela Substation, Puerto Rico, in trials that received low levels of N (20 kg/ha) fertilization. Several lines from the cross 'PR0518-10/PR0401-257' had superior performance in this low-N environment. A few of these lines had superior performance in BASE trials conducted at the Isabela Substation over a four-year period (Beaver et al., 2019). One of these lines was formally released in Puerto Rico as the black bean cultivar 'Hermosa' that combines resistance to BGYMV and BCMV with greater tolerance to low soil fertility and high temperature (Beaver et al., 2018b). Porch et al. (2014a) released the small red bean germplasm line TARS-LFR1 and black bean germplasm lines TARS-MST1 and SB-DT1 (Porch et al., 2012) with superior performance in low fertility soils. It is noteworthy that all the breeding lines released in Puerto Rico with improved adaptation to low fertility soils also expressed root rot resistance.

Results from field trials conducted by Abruña et al. (1983) in Corozal and Isabela, Puerto Rico, demonstrated that seed yield of dry beans declined rapidly when soil $\mathrm{pH}$ was lower than 4.7 and $\mathrm{Al}$ saturation of the 
effective CEC of the soil was greater than $30 \%$. They also found a positive correlation between the Ca content in bean leaves and seed yield. Badillo-Feliciano and Lugo-López (1981) did not find a significant seed yield response of beans to liming on the Coto Clay (Oxisol) at the Isabela Substation that had a $\mathrm{pH}$ of 5.0. Abruña et al. (1974) reported that snap beans produced yields ranging from 6,800 to $13,600 \mathrm{~kg} / \mathrm{ha}$ when soils in Corozal, Isabela and Jayuya, Puerto Rico, were limed appropriately. Increased $\mathrm{Ca}$ and decreased Mn content in leaves, greater soil base content and increased snap bean yield were observed in response to liming.

Bueso-Campos (1989) conducted greenhouse studies to evaluate the effect of acidity, $\mathrm{Al}$ concentration, aeration and mechanical impedance of a Maricao clay (a strongly acid soil) on the development of the roots of the white bean line L-227-1. Roots were shorter, thicker and had less branching in soil treatments having greater levels of acidity and $\mathrm{Al}$ concentrations and/or more dense soils. Approximately $15 \%$ of soil aeration (relative oxygen diffusion coefficients of 0.05 to 0.06 ) was optimal for shoot growth. Mechanical resistance > 1.39 MPa began to restrict shoot and root growth.

Goenaga and Smith (2002) studied the response of common bean to soil Al concentration in field trials conducted at Corozal, Puerto Rico. An increase in soil Al concentration from $0.68 \mathrm{cmol} / \mathrm{kg}$ to $2.5 \mathrm{cmol} / \mathrm{kg}$ significantly reduced plant dry matter and reduced concentrations of leaf $\mathrm{P}, \mathrm{Ca}$ and $\mathrm{Mg}$. Concentrations of leaf $\mathrm{Fe}$ and $\mathrm{Al}$ increased in soils with greater $\mathrm{Al}$ concentration. The authors suggested that the selection of Ca-efficient genotypes may help to identify bean genotypes with greater Al tolerance. Smith and Goenaga (2004) conducted field trials in acid soils at the Corozal Substation to determine if a differential response to exchangeable soil $\mathrm{Al}$ in the seedling/vegetative stage is associated with response to exchangeable soil $\mathrm{Al}$ in mature snap bean plants. No association was found due to the complex response of snap bean plants to $\mathrm{Al}$ toxicity in acid soils.

\section{Biological Nitrogen Fixation}

Because many tropical soils are low in nitrogen, Schröder (1992) noted that biological nitrogen fixation (BNF) should play an important role in lower-input, sustainable agriculture systems. The common bean, unfortunately, contributes less to BNF than many other grain legumes. The short growing cycle of beans produced in Puerto Rico and the sensitivity of the symbiotic relationship to adverse environmental conditions such as acid soils, drought and high temperature create challenges to enhance BNF.

Velázquez et al. (1988) observed that inoculation is often unsuccessful because, after inoculation, locally adapted Rhizobuim strains with 
poor BNF capacity continue to occupy most of the nodules. MangualCrespo et al. (1987) observed in Juana Díaz, Puerto Rico, reduced nodule size and numbers on the cultivar 'Bonita' as the level of $\mathrm{N}$ fertilization increased from 0 to $360 \mathrm{~kg} / \mathrm{ha}$.

Cordero-García (1979) found the black bean cultivar 'La Vega' to produce the highest yield when inoculated with Rhizobium phaseoli. Cataño-Cataño (1990) conducted field trials at the Isabela Substation to compare traits related to biological nitrogen fixation of determinate and indeterminate bean lines in fertilized (50-100-50 kg/ha of NPK applied as granular fertilizer) and non-fertilized plots. All plots were inoculated with a mixture of Rhizobium etli (CIAT 632) and R. phaseoli (Viking 1 and Co-5) strains. Significant differences among lines were observed for nodule number, nodule dry weight, total $\mathrm{N}$ fixed, and $\mathrm{N}$ fixed per day. There were significant genotype $\mathrm{x}$ level of fertilizer $(0$ vs. $50 \mathrm{~kg} / \mathrm{ha}$ of N) interactions for nodule number and nodule weight. The Dominican red mottled landrace cultivars 'Pompadour B' (determinate) and 'Pompadour E' (indeterminate) had the best overall combinations of BNF characteristics including greater nodule numbers and dry weights.

Fernández-Toledo et al. (1997) evaluated nodulation of 30 elite lines planted during the winter and summer months at Isabela, Puerto Rico, over two years. The trials were not fertilized or inoculated to allow nodulation with endemic soil Rhizobium prevalent under environmental conditions in the area. The black bean line XAN 176 produced mean seed yields $>1,000 \mathrm{~kg} / \mathrm{ha}$ during both planting seasons and produced $>$ 50 nodules per plant (good according to the CIAT scale). Line XAN 176 also produced significantly greater nodule weight during the summer plantings than the small red cultivars 'Don Silvio' and 'Dorado' (DOR 364).

Heilig et al. (2017) evaluated the biological nitrogen fixation (BNF) characteristics in a RIL population from the cross between the black bean cultivars 'Puebla 152' and 'Zorro' in field trials conducted in East Lansing, Michigan, and Isabela, Puerto Rico. They identified 17 unique QTLs that were mostly found in clusters on Pv01, Pv06 and Pv08. Many of the QTLs associated with enhanced BNF or more efficient partitioning of $\mathrm{N}$ were associated with candidate genes expressed in roots and nodules. A QTL for seed yield in Puerto Rico on Pv03, contributed from the 'Puebla 152' parent, was identified in both 2012 and 2013.

Recent studies of the symbiosis between common bean and the nitrogen-fixing bacteria Rhizobium showed that it is important to determine which Rhizobium spp. strain is most effective for a specific genotype and environmental condition to achieve efficient nodulation and biological nitrogen fixation. Rosas et al. (2012) observed that Rhi- 
zobium tropici strain CIAT 899 increased nodule and plant biomass in bean cultivars 'Macuzalito' and 'Don Silvio RR' when compared with Rhizobium tropici strain CR 477. In contrast, G21212 performed better with strain CR 477 than with CIAT 899. A growth pouch experiment under controlled conditions (Estévez de Jensen et al., 2011) demonstrated red mottled line PR0737-2, inoculated with Rhizobium tropici strain CIAT 899, had higher nodule positions but fewer nodule numbers, whereas inoculation with UMR 1597 resulted in greater nodule numbers in PR0737-2. Conversely, the pink bean line PR0401-259 produced the highest number of nodules among the lines when inoculated with UMR 1899 and the least number of nodules when inoculated with UMR 1597. Lines PR0737-1 and TARS 10IS-2421 showed good nodulation in the uppermost root region when inoculated with either strain. Screenhouse trials were conducted at Juana Díaz, Puerto Rico, to examine the nodulation characteristics of 118 common bean and two tepary bean lines from the BASE 120 trial. The number of nodules on roots of plants inoculated with Rhizobium tropici strain CIAT 899 and Rhizobium etli strain CIAT 632 were significantly different $(P>0.05)$ among genotypes. Genotypes BFS 139 and 'ICA Pijao' had more than 50 nodules per plant in the upper $3 \mathrm{~cm}$ of the root in two of three trials (Estévez de Jensen et al., 2017).

Inheritance for nodulation traits was explored with RILs from a cross between 'Jamapa' (Mesoamerican) and 'Calima' (Andean). The RILs expressed a wide range in nodule number including lines that produced significantly more nodules than either parent and lines that produced very few nodules when inoculated with a specific Rhizobium strain. Some lines produced $>50$ nodules per plant. Narrow sense heritability estimates for nodule number per plant ranged from 0.40 to 0.59 and for nodulation score from 0.41 and 0.43 (Guachambala et al., 2013).

Uptake hydrogenase (Hup) activity oxidizes the hydrogen produced during nitrogen fixation and may lead to enhanced biological nitrogen fixation. Navarro et al. (1993) observed (Hup) activity in beans inoculated with Rhizobium tropici, although Hup activity was insufficient to eliminate hydrogen evolution from root nodules. Genotype x strain interaction was also observed for Hup activity.

\section{Bean seed quality characteristics}

Rodríguez-Sosa et al. (1984) studied water absorption and cooking properties of 22 dry bean lines and cultivars from the Caribbean. Differences among genotypes were observed in time to achieve $50 \%$ hydration. In sensory evaluations of the beans cooked using a traditional recipe from Puerto Rico, all the genotypes had acceptable appearance 
and flavor. Texture was the most important attribute contributing to the acceptability of cooked beans.

Hosfield and Beaver (2001) studied cooking time and water absorption of 37 dry bean lines and cultivars. A significant negative association $(\mathrm{r}=-0.84)$ between cooking time and water absorption was found. Pinto beans were the fastest cooking market class, whereas the smallred lines and cultivars from Central America were the slowest cooking.

Tulmann et al. (1978) found no relationship between percentage protein of dry bean seed from plants grown at different plant densities or from pods harvested from different positions on the plant. During the 1970s and 1980s, L. Telek and G. Freytag, USDA-ARS scientists based in Mayagüez, Puerto Rico, studied tannin and protein content of dry beans. In a personal communication from L. Telek, Shelli-Dessert and Bliss (1991) noted that a major difficulty in breeding for lower tannin content was the lack of a reliable assay for measuring tannin content in bean seed. Miklas (1995a) released three Mesoamerican bean germplasm lines that had higher levels of seed protein. One of the parents used as a source of higher protein was the small red breeding line 15R-148 developed by Freytag.

\section{Seed yield, phenology and breeding methods}

Bliss (1980) reported that common beans in Puerto Rico had outcrossing rates as high as 15 to $20 \%$ due to activities of the carpenter bee (Xylocopa brasilianorum L.). This report was a cause of concern for local bean breeding, seed production and winter nursery activities. Brunner and Beaver (1989) reported outcrossing rates of beans at the Isabela Substation were sufficiently low to permit the use of conventional methods for breeding self-pollinated crops. Dry bean winter nurseries have been conducted at the Isabela Substation for more than 35 years and genetic impurity has not presented a significant problem.

Beaver et al. (1985a) evaluated the yield stability of determinate and indeterminate red mottled bean lines based on trials conducted in the Dominican Republic. Indeterminate lines in the trials tended to have greater and more stable seed yields. Additional field trials were conducted in the Dominican Republic and Puerto Rico to compare the performance of determinate and indeterminate red mottled bean lines (Beaver et al., 1996). Indeterminate lines were identified for the most desirable combination of yield stability characteristics including high mean seed yields, coefficients of regression near unity and minimum deviations from regression.

Smith (2004) reported that the use of geometric means from stressed and non-stressed yield trials were effective in identifying the highestyielding lines across environments. Deviations from regression may be 
useful to identify new sources of stress tolerance in lines derived from wide crosses. Novel gene combinations for stress tolerance should be further studied and introgressed into genetic backgrounds with better adaptation.

Durán et al. (2005) described morphological and molecular characteristics of larger-seeded bean landraces from Puerto Rico, the Dominican Republic and Haiti. Bean landraces with indeterminate growth habits tended to produce higher seed yields than determinate landraces in field trials conducted at Isabela, Puerto Rico, over a two-year period. Several of the landraces with Andean seed types were found to have the S phaseolin allele from the Middle American gene pool, which suggested the lines were the result of inter-gene pool introgression.

Mateo-Solano et al. (1989) estimated heritabilities and phenotypic correlations for seed yield and morphological traits of indeterminate bean lines derived from crosses between small-seeded indeterminate and larger-seeded determinate genotypes. Greater seed yield was associated with greater numbers of branches and nodes, taller plants, greater biological yield and higher harvest indices. Heritability estimates for seed yield and morphological traits were generally low to intermediate. Replicated yield trials of advanced generation lines was suggested to be the most effective approach for identifying large-seeded indeterminate bean lines with greater seed yield potential.

Beaver and Kelly (1994) compared different selection methods for bean populations derived from crosses between gene pools. Recurrent selection with evaluation of $\mathrm{F}_{5}$ lines identified indeterminate lines having seed yields greater than determinate check cultivars. These indeterminate populations tended to have longer reproductive periods and a greater number of days to reach physiological maturity.

These results led to a breeding objective at the University of Puerto Rico to develop indeterminate Andean bean cultivars for the Caribbean. The indeterminate light red kidney cultivar 'Badillo' was released in Puerto Rico in 2010. The indeterminate and BGYMV resistant red mottled bean lines PR0737-1 and PR0633-10 were released in Puerto Rico and Haiti in 2014.

Unander et al. (1989) studied the yield stability of 25 small-seeded indeterminate breeding lines and cultivars of diverse origin based on results from 23 field trials conducted in Honduras. Although large rank order differences among genotypes were observed when mean seed yields of different seasons and departments (local production regions) were compared, a few entries in the trial were ranked in the top third in all seasons and departments.

Cerna and Beaver (1990) estimated the narrow sense heritabilities (NSH) of days to first flower, days to physiological maturity and length 
of the reproductive period (days between flowering and physiological maturity) of smaller-seeded indeterminate beans. The NSH estimates for days to first flower were sufficiently large to suggest early generation selection for this trait would be effective. Genetic correlations between days to first flower and reproductive period were, in large part, negative and significant. These results indicated that a longer reproductive period could be achieved by selecting lines for reduced days to first flower.

Beaver and Rosas (1998) further studied the lengths of reproductive periods and the rates of seed mass accumulation of smaller-seeded indeterminate beans. The NSH of reproductive periods ranged from intermediate (0.43) to high (0.83), whereas NSH estimates for rates of seed weight accumulation were low (0.24). Higher-yielding lines were identified that combined longer reproductive periods with greater rates of seed weight accumulation.

University of Puerto Rico researchers collected field data in Isabela for collaborative research designed to better understand the response of beans to different photoperiod and temperature regimes (Bhakta et al., 2017; Wallace et al., 1995). Other collaborative bean field trials were conducted to study rates of biomass accumulation and partitioning of biomass into seed yield (Wallace et al., 1993).

Ramírez-Builes et al. (2008) developed linear models to estimate leaflet area of Mesoamerican common bean. Linear models using the maximum leaflet lengths and widths produced reliable estimates of leaflet area under greenhouse and field conditions and at different stages of development of the bean plant.

The University of Puerto Rico and other bean research programs in Central America and the Caribbean have limited resources, increasing the utility of small plot sizes. Beaver and Kelly (1989) studied the performance of determinate and indeterminate bean lines planted in replicated 1-m hill-plots in populations ranging from 2 to 10 plants. Number of seeds per pod and 100-seed weight were not significantly different in 1-m hill-plots ranging from 2 to 10 plants per hill-plot. Seed yield per plant increased in a linear fashion as number of plants per hill-plot decreased. Seed yield per hill-plot of both determinate and indeterminate plants decreased in a linear fashion as the number of plants per hill-plot decreased. A covariance analysis using numbers of plants per hill-plot as the covariate could be used to adjust seed yields for variation in plant populations in hill-plots.

Grain legume breeders can harvest whole pods rather than single seeds to advance generations of breeding populations of self-pollinated crops. This is an especially valuable tool for bean breeders working in the tropics where multiple generations per year can be planted. Re- 
sults from a simulation study (Macchiavelli and Beaver, 2001) showed that an increase in the number of whole pods harvested from the $\mathrm{F}_{2}$ to the $\mathrm{F}_{6}$ generation did not influence significantly the mean proportion of $\mathrm{F}_{2}$ plants represented in the $\mathrm{F}_{6}$ generation, although variability decreased. Using this multiple-seed procedure, bean breeders could expect that at least every third $\mathrm{F}_{6}$ line would be derived from a different $F_{2}$ plant, which should preserve enough genetic variability for the selection of quantitatively inherited traits such as seed yield.

\section{Winter Nurseries}

In 1935, Rexford Tugwell, Under Secretary of the U.S. Department of Agriculture, requested a report to re-evaluate the role of the USDA Puerto Rico Agricultural Experiment Station. One recommendation was that winter nurseries in Puerto Rico could assist continental U.S. maize (Zea mays L.) breeding programs. This proved to be a very valuable recommendation not only for maize breeders but for breeders of many other crops. The USDA-ARS Tropical Agriculture Research Station has several decades of experience hosting winter nurseries for maize and soybeans and conducting a backcrossing program to convert tropical sorghum [Sorghum bicolor (L.) Moench] germplasm into genotypes that allow their performance to be evaluated under temperate conditions (Sotomayor-Ríos and Torres-Cardona, 1984).

Since 1981, the University of Puerto Rico has planted dry bean winter nurseries for bean breeding programs from Michigan State University, the University of Nebraska, North Dakota State University and the USDA-ARS. The winter nursery is a collaborative activity of Regional Hatch Project W-3150 (https://www.nimss.org/). The winter nurseries have enabled public bean breeders from the U.S. to advance early-generation breeding lines at a more rapid pace and to evaluate material for reaction to diseases such as common bacterial blight and rust. Reciprocally, the winter nursery provides the University of Puerto Rico bean breeding program with an opportunity to evaluate lines from different bean breeding programs for adaptation to local conditions. Most of the bean cultivars released during the past 20 years by Michigan State University, North Dakota State University and the University of Nebraska had at least one generation planted in winter nurseries in Puerto Rico during their development. Planting beans in the winter nursery allows indirect selection for adaptation to the lowland tropics. Farmers in some countries such as the Petén region of Guatemala and southern Mexico have recognized this adaptation and have adopted black bean cultivars such as 'Zorro' from Michigan (Kelly et al., 2009).

The private sector also provides winter nursery services in Puerto Rico for bean breeding programs in North America. In recent years, 
Illinois Crop Improvement ${ }^{7}$ and Third Millennium Genetics have provided winter nursery services for public and private bean breeding programs.

\section{Tepary bean}

Wild relatives of common bean and related species, including $P$. acutifolius, $P$. coccineus, $P$. costaricensis and $P$. dumosus, represent valuable sources of genetic diversity for the improvement of common bean (Porch et al., 2013b). Interspecific crosses with the tepary bean have been used to improve resistance of common bean to common bacterial blight (Singh and Miklas, 2015) and bruchids (Kusolwa and Myers, 2011).

Seminal research on the origins and diversity of wild Phaseolus sp., including tepary bean, over several decades in Puerto Rico and Colombia resulted in a monograph for the Phaseolus genus by Freytag and Debouck (2002). In the 1980s, taxonomic data were collected on wild Phaseolus germplasm in screenhouses and growth chambers at ARSTARS in Mayagüez and in the field at agricultural experiment substations across Puerto Rico. In addition to taxonomic studies, protein gel electrophoresis was used to elucidate the diversity within and between Phaseolus species with the greatest diversity found within wild types of $P$. acutifolius (Sullivan and Freytag, 1986).

Interest in tepary population structure, genetic diversity, and applications in breeding has continued. Recent research at the ARS-TARS using GBS-developed SNP markers assayed across the Tepary Diversity Panel (TDP) composed of 156 domesticated and 158 wild tepary accessions, found eight sub-populations of tepary bean, two domesticated and six wild. The results affirm a bottleneck effect as a result of domestication where domesticated tepary bean is narrow genetically, while the wild sub-populations harbor most of the genetic diversity (Hart et al., 2019).

The first published record of tepary bean field evaluations in Puerto Rico showed low yields for the 'White tepary' bean variety (Snyder, 1918). 'White tepary' was then crossed with the common bean 'Puerto Rico Red' and hybrids were produced but subsequently lost due to bacterial blight disease (Snyder, 1918). The next records of tepary evaluation in Puerto Rico were field trials of wild P. acutifolius in the 1980s

${ }^{7}$ The USDA is an equal opportunity provider and employer. Mention of company or trade names or commercial products in this publication is solely for the purpose of providing specific information and does not imply recommendation or endorsement by the U.S. Department of Agriculture or by the Agricultural Experiment Station of the University of Puerto Rico. 
at the Fortuna Substation in Juana Díaz (Freytag and Debouck, 2002). Later, field evaluations of eleven domesticated tepary bean lines in Puerto Rico and Honduras, from 1989 to 1994, determined production potential for the crop (Miklas et al., 1994b). Recent multi-year evaluations of the TDP in Puerto Rico and Honduras (Rodríguez, 2017) show similar yield potential between tepary and common bean under nonstress, but superior yield potential of tepary bean under drought stress (Porch et al., 2009). There is no record of commercial production of tepary bean in Puerto Rico.

Tepary bean shows broad abiotic stress tolerance, but it has limited disease resistance, likely due to less exposure to pathogens in its arid origin and no history of modern crop improvement methods. Although relatively little work has been done on tepary bean response to disease, much of the published research was conducted in Puerto Rico. Vakili (1976) evaluated tepary bean response to root rot, rust, common bacterial blight and BCMV. Tepary bean was susceptible to Bean common mosaic virus (BCMV) in Puerto Rico, and a $25 \%$ seed transmission rate of BCMV was observed (Kaiser, 1981). Recent BCMNV evaluations of the TDP found less pronounced symptoms in tepary bean as compared to common bean under high temperature screenhouse conditions. Susceptible accessions, as determined using ELISA, often show no phenotypic symptoms or symptoms that differ from those in common bean. Using ELISA and phenotypic evaluation, only one accession in the TDP was found to be resistant to the NL-3 strain of BCMNV. A GWAS of the TDP based on NL-3 ELISA results identified two preliminary genomic regions conferring resistance to BCMNV (unpublished). A set of 12 domesticated tepary bean lines were evaluated for response to BGYMV in Juana Díaz with four lines showing tolerance under these conditions (Miklas and Santiago, 1996), while a small subset of the TDP showed tolerance to BGYMV at Zamorano in Honduras in 2015 (unpublished). Miklas et al. (1998a) did a follow-up study on the 12 tepary lines and three showed resistance to ashy stem blight, and to Fusarium wilt, caused by Fusarium oxysporum, while one line, PI 321637-s, showed tolerance to all three pathogens. Field screening of breeding lines has resulted in improved resistance to ashy stem blight. However, collaborative evaluations with Colorado State University over multiple years found no resistance to the Fusarium solani root rot strain(s) endemic at the Agricultural Research, Development and Education Center in Ft. Collins within the breeding lines and TDP accessions evaluated. Conversely, tepary lines were identified with resistance to the local root rot complex, that includes Fusarium solani, in the TARS Isabela root rot nursery (Porch, Personal communication). In collaboration with the University of 
Puerto Rico, breeding lines were evaluated for bruchid resistance and selected for release (Porch et al., 2013a). Inheritance of resistance to $\mathrm{CBB}$ and rust in select tepary bean lines was already described in earlier sections. Additionally, evaluation of a tepary RIL population to two Xcp strains found four QTL conditioning CBB resistance at 21 days after inoculation (Rodríguez, 2017).

The response of tepary bean to high temperature stress (summer trials) and drought (winter trials) were conducted in the semi-arid UPR Fortuna Substation in Juana Díaz over multiple years during the 2010s and 1990s (Miklas et al., 1994b). In these trials, tepary bean yielded less than common bean in the non-stress environment and yielded $170 \%$ of common bean in the high temperature Juana Díaz location (Miklas et al., 1994b). Recent evaluations of the TDP, breeding lines, and G40001 x G40022 RIL population showed exceptional heat tolerance with little or no reduction in yields under average maximum $\left(33^{\circ} \mathrm{C}\right)$ and minimum $\left(23^{\circ} \mathrm{C}\right)$ temperatures present at the Juana Díaz location. Terminal drought stress did result in seed yield reduction, with variability in response found and QTLs identified for yield in the RIL population (Rodríguez, 2017). Traub et al. (2018) showed key photosynthetic advantages of TB1, a tepary bean previously tested in Puerto Rico (Ramírez et al., 2009), compared to common bean lines developed for drought tolerance. The introgression of drought tolerance from wild tepary bean to common bean, by the University of Saskatoon, was shown in collaborative drought and non-stress evaluations at the Isabela Agricultural Experiment Substation (Souter et al., 2017).

The TDP and two interspecific $(\mathrm{Pv} \times \mathrm{Pa})$ populations were evaluated for their ability to nodulate with Rhizobium and Bradyrhizobium strains. Bradyrhizobium strain USDA 3254 was found to be broadly efficient in tepary bean. Of the TDP accessions, G 40142 and G 40161 exhibited superior ability to nodulate with strain USDA 3254. Transgressive interspecific lines were identified that showed superior nodulation scores compared to their parents (Vargas-Palacios, 2016). Future studies could involve selection of both bacteria and host for improved nodulation under abiotic stress.

A study on elemental composition and cooking time found tepary bean within the range of common bean for cooking time, elemental and overall nutritional composition (Porch et al., 2016). The exceptions were tepary, which had a significantly higher sucrose concentration and reduced fat and ash concentrations compared to common beans. Previous research in Puerto Rico showed reduced proanthocyanidin (tannins, an anti-nutritional factor) in the tepary lines evaluated compared to 'Dorado' small red bean (Miklas et al., 1994b). Continued pro- 
motion of tepary bean, such as the use of TARS-Tep 22 for the Culinary Breeding Network's 2016 Variety showcase in Oregon may contribute to its broader culinary adoption.

Since 2008, ARS-TARS has focused on improving tepary bean germplasm by generating novel genetic variability for seed quality, and disease and insect resistance, using traditional hybridization between selected tepary accessions (Porch and Beaver, 2012). TARS-Tep 22, a white seeded type with common bacterial blight, rust, and bruchid resistance, and with more erect architecture (Porch et al., 2013a), is the first release from this breeding effort. Another release TARS-Tep 32 , with larger seed size and bacterial blight resistance, was selected from a yellow seeded landrace PI 477033. Both releases are broadly adapted with good yield under drought and higher temperature conditions. Efforts to introgress disease resistance from common bean to tepary bean were largely unsuccessful due to the wide genetic distance between species. A shuttle breeding program has been used by USDAARS-TARS and Colorado State University bean breeders to develop broadly adapted tepary bean breeding lines.

Through an ongoing collaboration with Michigan State University, North Dakota State University, University of Saskatchewan, and Hudson Alpha, the tepary bean genome is being sequenced from a widely studied accession, G40001 (Buell et al., 2018). This tepary bean genotype was previously used in the development of the core RIL population G40001 x G40022, because it exhibits key traits such as broad adaptation, good seed quality, low soil fertility tolerance and leafhopper resistance. It also shows resistance or tolerance to common bacterial blight, angular leaf spot, and web blight.

\section{Lima beans}

The lima bean is a traditional crop in the Caribbean. Hendricksen (1906) reported that lima beans with 'sieva' seed types were produced in Puerto Rico on a limited scale. Lima beans are referred to in Puerto Rico as 'habas'. Most landraces in Puerto Rico have an indeterminate growth habit and are often found growing on fence rows (Montero-Rojas et al., 2012). Caribbean lima bean landraces tend to be photoperiod sensitive and produce pods during the dry winter months. Lima beans are more heat and drought tolerant than common beans (Beebe et al., 2013). These traits contribute to food security in countries such as Haiti where significant areas of lima beans are planted each year.

Mackie (1943) noted that lethal levels of hydrocyanic acid (HCN) were found in some lima bean landraces from Puerto Rico. Montero-Rojas et al. (2013) reported that outbreaks of poisoning due to consumption of lima beans were reported in Puerto Rico during the beginning 
of the $20^{\text {th }}$ century. Viehoever (1940) identified a lima bean landrace 'Puerto Rico black' with HCN concentration of $3,000 \mathrm{mg} / \mathrm{L}$. The lima bean landrace variety, 'L-121', from Puerto Rico was used to study the inheritance of anti-A1 hemagglutinating activity (Schertz et al., 1960).

In 1933, the USDA-PRAES and the College of Agricultural Science of the University of California cooperated in the evaluation of seven lima bean cultivars from California. The pole lima bean 'King of the Garden' landrace cultivar produced the highest yield at four months after planting. In the 1938 report of the USDAAES in Mayagüez, sieva landraces of lima bean from Puerto Rico were found to be resistant to pod borers and seed was sent to interested researchers in the United States.

Mackie (1943) noted that some smaller-seeded lima beans had nematode resistance. Allard (1954) screened 261 lines from the California Agricultural Experiment Station Accession and Introduction Collection for reaction to root-knot nematode (Meloidogyne incognita). Among the 12 lines identified to have resistance, six lines were from Puerto Rico (L-32, L-136, L-137, L-139, L-141 and L-142). The root-knot nematode resistant lima bean cultivar 'Cariblanco N' was released by the California Agricultural Experiment Station in 2001 (Helms et al., 2004). 'Cariblanco N' was derived from a cross that used L-136 as the source of root-knot nematode resistance.

Mackie (1943) presented color plates of lima bean landraces from Puerto Rico. Unfortunately, these lines were not included in the USDA bean germplasm collection. At present, there are only two accessions of lima bean from Puerto Rico in the USDA germplasm collection. Ruiz et al. (2010) evaluated 15 lima bean landraces from Puerto Rico in a trial planted at Isabela. They reported significant differences among landraces for seed, leaf and pod type, days to flowering, seed yield and concentration of HCN in the leaves and seed. In Puerto Rico, PL-08-14 was the only landrace cultivar that had early flowering (51 DAP) with a HCN concentration $<100 \mathrm{mg} / \mathrm{L}$ in the seed, which is the maximum concentration recommended for the release of lima bean cultivars in the United States. MonteroRojas et al. (2013) evaluated the agro-morphological characteristics of the collection of 50 landraces from Puerto Rico, the Dominican Republic and Haiti. These Caribbean lima bean landraces were found to belong to the Middle American gene pool. A few of these lima bean landraces had the desirable combination of high levels of the cyanogenic glucoside linamarin in the leaves (favorable for pest control), and low levels of linamarin in the seeds. This collection of Caribbean lima bean landraces was included as accessions in the CIAT bean germplasm bank. 


\section{LITERATURE CITED}

Abawi, G.S. and T.L. Widmer, 2000. Impact of soil health management practices on soilborne pathogens, nematodes and root diseases of vegetable crops. Applied Soil Ecol. 15: $37-47$.

Abruña, F., J.A. Rodríguez-García and J. Badillo-Feliciano, 1983. Crop response to soil acidity factors in Ultisols and Oxisols in Puerto Rico. VII. Dry Beans. J. Agric. Univ. P. R. 67: 429-437.

Abruña, F., R. Pérez-Escolar, J. Vicente-Chandler, J. Figarella and S. Silva, 1974. Response of green beans to acidity factors in six tropical soils. J. Agric. Univ. P. R. 58: 44-58.

Acevedo-Román, M., J.R. Steadman and J.C. Rosas, 2013. Uromyces appendiculatus in Honduras: Pathogen diversity and host resistance screening. Plant Dis. 97: 652661.

Acevedo-Román, M., A. Molina-Castañeda, J.C. Angel-Sánchez, C.G. Muñoz and J.S. Beaver, 2004. Inheritance of normal pod development in bean golden yellow mosaic resistant common bean. J. Amer. Soc. Hort. Sci. 129: 549-552.

Adames-Mora, C., J.S. Beaver and O. Diaz, 1996. Un método de evaluación del virus del mosaico dorado de habichuela en el invernadero. J. Agric. Univ. P. R. 80: 65-72.

Allard, R.W., 1954. Sources of root-knot nematode resistance in lima beans. Phytopathology 44:1-4.

Aponte-Rivera, J.L., 2004. Selección recurrente para resistencia a la mustia hilachosa de habichuela (Phaseolus vulgaris L.). M.S. Thesis. University of Puerto Rico, Mayagüez, PR. 66p.

Arias, J., G. Godoy de Lutz, Y. Segura, E. Arnaud, J. Beaver and J.R. Steadman, 2010. DPC-40 IDIAF: Nueva variedad de fríjol negro (Phaseolus vulgaris L.) con resistencia a begomovirus y potyvirus. Proceedings of the 46th Annual Meeting of the Caribbean Food Crops Society held in Santo Domingo, Dominican Republic. 1 p.

Arnaud-Santana, E., D.P. Coyne, J.R. Steadman, A.K. Vidaver, K.M. Eskridge and J.S. Beaver, 1992. Heritabilities of seed transmission and leaf and pod reactions to common blight, leaf reaction to web blight, plant architecture and their associations in dry beans (Abstract). HortSci. 27: 109.

Azzam, O., O. Díaz, J.S. Beaver, R.L. Gilbertson, D.R. Russell and D.P. Maxwell, 1996. Transgenic beans with bean golden mosaic gemnivirus coat protein gene are susceptible to virus infection. Ann. Rep. Bean Improv. Coop. 39: 276-277.

Azzam, O., J. Frazer, D. de la Rosa, P. Ahlquist, J.S. Beaver and D.P. Maxwell, 1994. Whitefly transmission and efficient ssDNA accumulation of bean golden mosaic virus require the expression of the coat protien. Virology 204: 289-296.

Badillo-Feliciano, J., I. Reyes-Soto and J. Beaver, 1985. A comparison of yields of common bean at physiological and harvest maturity. J. Agric. Univ. P. R. 69: 19-24.

Badillo-Feliciano, J. and M.A. Lugo-López, 1981. An attempt to evaluate the effect of varying time intervals between liming and cropping on an Oxisol. J. Agric. Univ. P. R. 65: 83-89.

Badillo-Feliciano, J., M.A. Lugo-López and T.W. Scott, 1978. Effect of planting distance on yield and agronomic characteristics of red kidney and native white beans in an Oxisol. J. Agric. Univ. P. R. 62: 145-148.

Baiges, S., J.S. Beaver, P.N. Miklas and J.C. Rosas, 1996. Evaluation and selection of dry beans for heat tolerance. Annu. Rep. Bean Improv. Coop. 39: 88-89.

Bautista-Pérez, M. and R. Echávez-Badel, 2000. Methodology for screening common bean resistance to web blight. J. Agric. Univ. P. R. 84: 91-94.

Bautista-Pérez, M., R. Echávez-Badel and R.E. Macchiavelli, 2000. Virulence of Rhizoctonia solani isolates associated with web blight of common bean. J. Agric. Univ. P. R. 84: 95-97.

Bean Institute, 2018. Dry beans commonly consumed (by nationality). http://beaninstitute.com/wp-content/uploads/2014/04/Bean-consumption-by-nationality_1.pdf

Beaver, J.S., T.G. Porch, G. Lorenzo-Vázquez, A. González and C. Estévez de Jensen. 2019. Performance of Mesoamerican beans in a low fertility soil. Ann. Rep. Bean Improv. Coop. 62: 91-92. 
Beaver, J.S., C. Estévez de Jensen, G. Lorenzo-Vázquez, A. González, H. Martínez and T.G. Porch, 2018a. Registration of 'Bella' white-seeded common bean cultivar. J. Plant. Reg. 12: 190-193.

Beaver, J.S., C. Estévez de Jensen, L.R. Quiles, G. Vázquez, A. González, H. Martínez and T.G. Porch, 2018b. Release of 'Hermosa' black bean cultivar. J. Agric. Univ. P. R. 102: 123-128.

Beaver, J.S., A. González, Y. Trukhina and T.G. Porch, 2016a. Development of a black bean line that combines bruchid and multiple virus resistance. Ann. Rep. Bean Improv. Coop. 59: 15-16.

Beaver, J.S., E. Prophete, G. Démosthène and T.G. Porch, 2016b. Registration of PR1146138 yellow bean germplasm line. J. Plant Reg. 10: 145-148.

Beaver, J.S., J.C. Rosas, T.G. Porch, M.A. Pastor-Corrales, G. Godoy de Lutz and E.H. Prophete, 2015. Registration of PR0806-80 and PR0806-81 white bean germplasm Lines with resistance to BGYMV, BCMV, BCMNV, and rust. J. Plant Reg. 9: 208-211.

Beaver, J.S., E.H. Prophete, J.C. Rosas, G. Godoy de Lutz, J.R. Steadman and T.G. Porch, 2014. Release of 'XRAV-40-4' black bean (Phaseolus vulgaris L.) cultivar. J. Agric. Univ. P. R. 98: 83-87.

Beaver, J.S., M. Zapata, M. Alameda, T.G. Porch and J.C. Rosas, 2012. Registration of PR0401-259 and PR0650-31 dry bean germplasm lines. J. Plant Reg. 6: 81-84.

Beaver, J.S., G. Godoy de Lutz, J.R. Steadman and T.G. Porch, 2011. Release of 'Beníquez' white bean (Phaseolus vulgaris L.) cultivar. J. Agric. Univ. P. R. 95: 237-240.

Beaver, J.S., T.G. Porch and M. Zapata, 2010. Registration of 'Badillo' light red kidney bean. J. Plant Reg. 4: 1-4.

Beaver, J.S. and J.M. Osorno, 2009. Achievements and limitations of contemporary common bean breeding using conventional and molecular approaches. Euphytica 168: $145-175$.

Beaver, J.S., T.G. Porch and M. Zapata, 2008. Registration of 'Verano' white bean. J. Plant Reg. 2: 187-189.

Beaver, J.S., J.M. Osorno, F.H. Ferwerda and C.G. Muñoz-Perea, 2005. Registration of bean golden yellow mosaic virus resistant germplasms PR9771-3-1, PR0247-49 and PR0157-4-1. Crop Sci. 45: 2126-2127.

Beaver, J.S., J.C. Rosas, J. Myers, J. Acosta, J.C. Kelly, S. Nchimbi-Msolla, R. Misangu, J. Bokosi, S. Temple, E. Arnaud-Santana and D.P. Coyne, 2003. Contribution of the Bean/Cowpea CRSP to cultivar and germplasm development in common bean. Field Crop Res. 82: 87-102.

Beaver, J.S., J. Steadman and G. Godoy de Lutz, 2002. Bean rust research in the Caribbean. Ann. Rep. Bean Improv. Coop. 45: 132-133.

Beaver, J.S., G. Godoy de Lutz, J.C. Rosas and J.R. Steadman, 2001. Estrategias para seleccionar frijol común con mayor resistencia a mustia hilachosa. Agronomía Mesoamericana 13(1): $67-72$.

Beaver, J.S., 2000. Effect of harvest date and seed type on green-shell and dry bean yield. J. Agric. Univ. P. R. 84: 29-30.

Beaver, J.S. and P.N. Miklas, 1999. Registration of 'Morales' small white bean. Crop Sci. 39: 1259 .

Beaver, J.S., P.N. Miklas and R. Echávez-Badel, 1999a. Registration of 'Rosada Nativa' pink bean. Crop Sci. 39: 1257.

Beaver, J.S., M. Zapata and P.N. Miklas, 1999b. Registration of PR9443-4, bean germplasm resistant to bean golden mosaic, common bacterial blight and rust. Crop Sci. 39: 1262 .

Beaver, J.S. and J.C. Rosas, 1998. Heritability of the length of the reproductive period and rate of seed mass accumulation in common beans. J. Amer. Soc. Hort. Sci. 123(3): 407-411.

Beaver, J.S., P.N. Miklas, J.D. Kelly, J.R. Steadman and J.C. Rosas, 1998. Registration of PR9357-107 small red germplasm resistant to BCMV, BCMNV and rust. Crop Sci. 38: 1406-1407.

Beaver, J.S., E. Arnaud-Santana and D.P. Coyne, 1996. Yield stability of determinate and indeterminate red mottled beans. J. Agric. Univ. P. R. 80: 187-189. 
Beaver, J.S. and J.D. Kelly, 1994. Comparison of selection methods for dry bean populations derived from crosses between gene pools. Crop Sci. 34: 34-37.

Beaver, J.S. and O. Román-Hernández, 1994. Green-shell bean production in Puerto Rico at different planting dates. J. Agric. Univ. P. R. 78: 131-136.

Beaver, J.S., C. Adames Mora and D. de la Rosa, 1994. Screening for bean golden mosaic virus resistance in the greenhouse. Ann. Rep. Bean Improv. Coop. 37: 35-36.

Beaver, J.S., J.R. Steadman and D.P. Coyne, 1992a. Field reaction of landrace components of red mottled beans to common bacterial blight. HortScience 27: 50-51

Beaver, J.S., J.R. Steadman and D.P. Coyne, 1992b. Atypical symptom expression of common bacterial blight in tropical pompadour germplasm. Ann Rep. Bean Improv. Coop. 35: 110.

Beaver, J.S., R. Echávez-Badel and G. Freytag, 1990a. Registration of 'Arroyo Loro' white bean. Crop Sci. 30: 746 .

Beaver, J.S., M. Martínez and G. Godoy, 1990b. Evaluation of dry beans for resistance to ashy stem blight. J. Agric. Univ. P. R. 74: 349-355.

Beaver, J.S. and J.D. Kelly, 1989. Yield compensation of beans grown in hill-plots. HortSci. 24: 137-138.

Beaver, J.S., O. Román-Hernández and L.E. Rivera, 1988. Dry beans and varying cultural practices at two locations on the coastal plain of Puerto Rico. J. Agric. Univ. P. R. 72: 521-530.

Beaver, J.S., C.V. Paniagua, D.P. Coyne and G.F. Freytag, 1985a. Yield stability of dry bean genotypes in the Dominican Republic. Crop Sci. 25: 923-926.

Beaver, J.S., C. Paniagua, J.R. Steadman and R. Echavez-Badel, 1985b. Reaction of dry bean genotypes to natural infection of foliar diseases when grown in the Dominican Republic. J. Agric. Univ. P. R. 69: 283-290.

Beebe, S.E., I.M. Rao, M.W. Blair and J.A. Acosta-Gallegos, 2013. Phenotyping common beans for adaptation to drought. Front. Physiol. 4(35): 1-20.

Beebe, S.E. and M. Pastor-Corrales, 1991. Breeding for disease resistance. p. 561-617. In A. van Schoonhoven and O. Voysest (ed.). Common bean research for crop improvement. CAB Int., Wallingford, U.K. and CIAT, Cali, Colombia.

Bhakta, M.S., S.A. Gezan, J.A. Clavijo Michelangeli, M. Carvalho, L. Zhang, J.W. Jones, K.J. Boote, M.J. Correll, J.S. Beaver, J.M. Osorno, R. Colbert, I. Rao, S. Beebe, A. Gonzalez, J. Ricaurte and C. E. Vallejos, 2017. A predictive model for time-to-flowering in the common bean based on QTL and environmental variables. G3: Genes, Genomes, Genetics 7(12): 3901-3912.

Bird, J. and K. Maramorosch, 1978. Viruses and virus diseases associated with whiteflies. Advances in Virus Research 22: 55-110.

Bird, J., R.L. Rodríguez, A. Cortés Monllor and J. Sánchez, 1977. Transmisión del mosaico dorado de la habichuela (Phaseolus vulgaris) en Puerto Rico por medios mecánicos. Fitopatología 12: 28-30.

Bird, J., J. Sánchez, R.L. Rodríguez and F.J. Julia, 1975. Rugaceous (whitefly-transmitted) viruses in Puerto Rico. In Tropical diseases of legumes. J. Bird and K. Maramorosch (eds.). Academic Press, New York, NY. p. 3-25.

Bird, J., J. Sánchez, R.L. Rodríguez, A. Cortés-Monllor and W. Kaiser, 1974. A mosaic of beans (Phaseolus vulgaris L.) caused by a strain of common cucumber mosaic virus. J. Agric. Univ. P. R. 58: 151-161.

Bird, J., J. Sánchez and N.G. Vakili, 1973. Golden yellow mosaic of beans (Phaseolus vulgaris) in Puerto Rico. Phytopathology 63: 1435.

Bird, J., J.E. Pérez, R. Alconero, N.G. Vakili and P.L. Meléndez, 1972. A whiteflytransmitted golden-yellow mosaic of Phaseolus lunatus in Puerto Rico. J. Agric. Univ. P. R. 56: 64-67.

Bird, J. and J. Sánchez, 1971. Whitefly-transmitted viruses in Puerto Rico. J. Agric. Univ. P. R. 55: 461-467.

Blair, M.W., L.M. Rodriguez, F. Pedraza, F. Morales and S. Beebe, 2007. Genetic mapping of the bean golden yellow mosaic geminivirus resistance gene bgm-1 and linkage with potyvirus resistance in common bean (Phaseolus vulgaris L.). Theor. Appl. Genet. 114: 261-271. 
Blair, M.W., M.J. Bassett, A.M. Abouzid, E. Hiebert, J.E. Polston, R.T. McMillan, W. Graves and M. Lamberts, 1995. Occurrence of bean golden mosaic virus in Florida. Plant Dis. 79: 529-533.

Blair, M.W. and J.S. Beaver, 1993a. Inheritance of bean golden mosaic virus resistance from bean genotype A-429. Ann. Rep. Bean Improv Coop. 36: 143.

Blair, M.W. and J.S. Beaver, 1993b. Sweetpotato whitefly reference differs among the Mesoamerican and Andean gene pools of common bean (Phaseolus vulgaris L.). Ann. Rep. Bean Improv. Coop. 36: 132-134.

Blair, M.W., J.S. Beaver and C. Adames, 1993a. Inheritance of the dwarfing response to bean golden mosaic virus infection in dry beans (Phaseolus vulgaris L.). Ann. Rep. Bean Improv. Coop. 36: 144-145.

Blair, M.W., J.S. Beaver and J.C. Rosas, 1993b. Heritability of field resistance to bean golden mosaic virus in dry beans (Phaseolus vulgaris L.). p. 160-170. In Bean Golden Mosaic - 1994 Research Advances. F. Morales (ed). Centro Internacional de Agricultura Tropical (CIAT), Cali, Colombia.

Blair, M., J.S. Beaver, J.C. Rosas and F. Saladin, 1992. Inheritance of field resistance of bean golden mosaic virus resistance in dry beans (Phaseolus vulgaris). Ann. Rep. Bean Improv. Coop. 35: 48-49.

Bliss, F.A., 1980. Common bean. p. 273-284. In Hybridization of crop plants. W.R. Fehr and H.H. Hadley (ed.). American Soc. of Agron. Madison, Wisconsin.

Bokosi, J.M., 1996. Sources of rust resistant germplasm and inheritance of rust reaction and hybrid plant abnormalities in common beans. $\mathrm{PhD}$ dissertation, Univ. of Nebraska, Lincoln Nebraska p. 170.

Bokosi, J.M., D.P. Coyne, J.R. Steadman, D. O’Keefe and J. Reiser, 1996. Inheritance and association of specific resistance to rust, flower color, and hypocotyl color, in recombinant inbred lines from common bean cross 'BelNeb RR-1 x A-55'. Ann. Rep. Bean Improv. Coop. 35: 304-305.

Brisco, E.I., T.G. Porch, P.B. Cregan and J.D. Kelly, 2014. Quantitative trait loci associated with resistance to Empoasca in common bean. Crop Sci. 54: 2509-2519.

Brunner, B., K. Brady, L. Flores and J. Beaver, 2014. Yield performance of eight snap bean genotypes grown under an organic management system in the tropics. J. Agric. Univ. P. R. 98: 15-20.

Brunner, B.F. and J.S. Beaver, 1989. Estimation of outcrossing of the common bean in Puerto Rico. HortSci. 24: 669-671.

Buell, C.R., K. Bett, P. McClean, S. Mafi Moghaddam, T. Porch, J. Schmutz, T.D. Sharkey and S.M. Weraduwage, 2018. Generating a reference genome for tepary bean (Phaseolus acutifolius): A highly heat tolerant species. Ann. Rep. Bean Improv. Coop. 61: 49-50.

Bueso-Campos, M.L., 1989. Efecto de la acidez, aireación y resistencia mecánica del suelo sobre el desarrollo y morfología de raíces de frijol (Phaseolus vulgaris L.). M.S. Thesis. Univ. of Puerto Rico. Mayagüez, Puerto Rico 96 p.

Cataño-Cataño, H., 1990. Selección de genotipos de Phaseolus vulgaris L. capaces de nodular en la presencia de fertilizante nitrogenado. M.S. Thesis. Univ. of Puerto Rico. Mayagüez, Puerto Rico. 55 p.

Cerna, J. and J.S. Beaver, 1990. Inheritance of early maturity of indeterminate dry bean. Crop Sci. 30: 1215-1217.

Cerna, J. and J.S. Beaver, 1989. A visual indicator of the physiological maturity stage of indeterminate dry beans. J. Agric. Univ. P. R. 73: 361-366.

Cichy, K.A., T.G. Porch, J.S. Beaver, P. Cregan, D. Fourie, R.P. Glahn, M.A. Grusak, K. Kamfwa, D.N. Katuuramu, P. McClean, E. Mndolwa, S. Nchimbi-Msolla, M.A. Pastor-Corrales and P.N. Miklas, 2015. A Phaseolus vulgaris diversity panel for Andean bean improvement. Crop Sci. 55: 2149-2160.

Cordero-García, M., 1979. Efecto de la inoculación con Rhizobium phaseoli y la fertilización nitrogenada con el comportamiento de la habichuela seca. M.S. Thesis. Univ. of Puerto Rico. Mayagüez, Puerto Rico.

Coyne, D.P, J.R. Steadman, G. Godoy de Lutz, R. Gilbertson, E. Arnaud-Santana, J.S. Beaver and J.R. Myers, 2003. Contributions of the Bean/Cowpea CRSP to management of bean diseases. Field Crops Res. 82: 155-168. 
Coyne, D.P., R. Navarrete-Maya, M. Pastor-Corrales, A.K. Vidaver and M. Zapata, 1996. Proposed minimum standards for race designation of Xanthomonas campestris pv. phaseoli (Xcp) in Phaseolus species. Ann. Rep. Bean Improv. Coop. 39: 288-289.

Cruz, C., 1981. Effect of soil mulches on leafhopper (Empoasca spp.) populations and dry bean yield. J. Agric. Univ. P. R. 65: 79-80.

Cruz, C. and E. Cardona, 1981. Control of dry seed weevils with cooking oil. J. Agric. Univ. P. R. 65: 295-298.

Cruz, C., 1975. Chemical control of the leafhopper (Empoasca fabae Harris) on snap beans. J. Agric. Univ. P. R. 59:82-84.

de Ron, A.M., V. Kalavacharla, S. Álvarez-García, J.S. Beaver, A. Bedmar Villanueva, G. Carro-Huelga, P.A. Casquero, L. De la Rosa, M. Dworkin, M.Z. Galván, M.C. Gonçalves Vidigal, S. Gutiérrez, A. Lorenzana, S. Mayo-Prieto, T. Porch, A.P. Rodiño, A. Rodríguez-González, S. Sofkova-Bobcheva, V. Suárez-Villanueva, R.R. Mir and A. Hamid, 2019. Common bean genetics, breeding and genomics for adaptation to changing to new agri-environmental conditions. In: Genomic designing of climatesmart pulse crops (Ed: C. Kole). Springer Nature, Cham, Switzerland. p.1-106.

del Rio, L., P.R. Hepperly and J.S. Beaver, 1991. Dry bean seed quality in Honduras. J. Agric. Univ. P. R. 75: 125-137.

Del Valle, R., T.W. Scott and M.A. Lugo-López, 1981. Variable response of food crops to banded and broadcast residual fertilizer P on an Ultisol. J. Agric. Univ. P. R. 65: 171-189.

Dorcinvil, R., D. Sotomayor-Ramírez and J.S. Beaver, 2010. Agronomic performance of common bean (Phaseolus vulgaris L.) lines in an Oxisol. Field Crops Res. 118: 264272.

Durán, L.A., M.W. Blair, M.C. Giraldo, R. Macchiavelli, E. Prophete, J.C. Nin and J.S. Beaver, 2005. Morphological and molecular characterization of common bean landraces and cultivars from the Caribbean. Crop Sci. 45: 1320-1328.

Echávez-Badel, M. Alameda and J. Beaver, 2002. An improved artificial inoculation technique to screen common bean for web blight reaction in the field. Ann. Rep. Bean Improv. Coop. 45: 150.

Echávez-Badel, R., J.E. Gómez-Galué and M. Alameda-Lozada, 2000. Characterization of Rhizoctonia spp. isolates collected from Phaseolus vulgaris in Puerto Rico. J. Agric. Univ. P. R. 84: 79-86.

Echávez-Badel, R. and J.S. Beaver, 1987a. Resistance and susceptibility of beans to ashy stem blight. J. Agric. Univ. P.R. 71: 403-406.

Echávez-Badel, R. and J.S. Beaver, 1987b. Dry bean genotypes and Macrophomina phaseolina (Tassi) Goid in inoculated and non-inoculated field plots. J. Agric. Univ. P.R. 75: 385-390.

Estévez de Jensen, C., T.G. Porch and J.S. Beaver, 2017. Nodulation ability of different common bean genotypes from the BASE 120 trial after inoculation with Rhizobium. 2017 Feed the Future Legume Innovation Lab Grain Legume Research Conference. Ouagadougou, Burkina Faso. 13 to 18 August 2017. Poster.

Estévez de Jensen, C., C.L. Harmon and A. Vitoreli, 2013. First Report of Asian Soybean Rust Caused by Phakopsora pachyrhizi in Puerto Rico. Plant Disease 97: 1378.

Estévez de Jensen, C., O. Faria, T.G. Porch and J.S. Beaver, 2011. Speed of nodulation of UMR 1899 and UMR 1597 in common bean breeding lines. Ann. Rep. Bean Improv. Coop. 54: 158-159.

Faria, J.C., R.L. Gilbertson, S.F. Hanson, F.J. Morales, P. Ahlquist, O. Loniello and D.P. Maxwell, 1994. Bean golden mosaic geminivirus type ii isolates from the Dominican Republic and Guatemala: Nucleotide sequence, infectious pseudorecombinants, and phylogenetic relationship. Phytopathology 84: 321-329.

Fernández-Toledo, F., J.S. Beaver and E. Schroder, 1997. Nodulation and seed yield of common bean in moderate and high temperature environments. Ann. Rep. Bean Improv. Coop. 40: 55-56.

Freytag, G.F. and D.G. Debouck, 2002. Taxonomy, distribution and ecology of the genus Phaseolus (Leguminosae-Papilionoideae) in North America, Mexico and Central America. BRIT (Bot. Res. Inst. Texas), Ft. Worth. 
Freytag, G.F., 1989. Inheritance of resistance to three strains of common bacterial blight (Xanthomonas campestris) in the cultivated tepary bean (Phaseolus acutifolius var. latifolius). Ann. Rep. Bean Improv. Coop. 32: 101-102.

Freytag, G.F., J.D. Kelly, M.W. Adams, J. López-Rosa, J.S. Beaver and R. EchávezBadel, 1985. Registration of two navy bean germplasm lines L226-10 and L227-1 Crop Sci. 25: 714.

Freytag, G.F., M.J. Bassett and M. Zapata, 1982. Registration of XR-235-1-1 bean germplasm (Reg. No. GP42) Crop Sci. 22: 1268-1269.

Godoy de Lutz, G., Y. Segura, J.R. Steadman and P.N. Miklas, 2004. Presence of bean common mosaic necrotic virus in the Dominican Republic: A new challenge for dry bean breeders and growers in the Caribbean region. Annu. Rep. Bean Improv. Coop. 47: 119-120.

Godoy de Lutz, G., J. Arias, J.R. Steadman and K.M. Eskridge, 1996. Role of natural seed infection by the web blight pathogen in common bean seed damage, seedling emergence, and early disease development. Plant Dis. 80: 887-890.

Goenaga, R. and J.R. Smith, 2002. Dry matter production and leaf elemental concentrations of common bean grown on an acid Ultisol. J. Plant Nutrition 25: 103-112.

González-Martínez, N.A., 2004. Identification of new sources of resistance to web blight of common bean (Phaseolus vulgaris L.). M.S. Thesis. Univ. of Puerto Rico, Mayagüez, PR. 46 p.

González-Ríos, P. and A. Riollano, 1951. El mejoramiento de la habichuela blanca del país (Phaseolus vulgaris) por medio de la selección. Univ. P.R. Est. Exp. Agr. Bol. 94, 21 pp.

Goodman, R.M., J. Bird and P. Thongmeearkom, 1977. An unsual viruslike particle associated with golden yellow mosaic of beans. Phytopathology 67: 37-42.

Guachambala, M., 2013. Estudio de la herencia de los altos niveles de resistencia al tizón bacteriano, causado por Xanthomonas axonopodis pv. phaseoli, en el frijol común (Phaseolus vulgaris L.). Tesis de Maestría en Ciencias, Universidad de Puerto Rico, Recinto Universitario de Mayagüez, Puerto Rico. 53 p.

Guachambala, M., A. González, C. Estévez de Jensen, J.S. Beaver and T.G. Porch, 2013. Root traits and nodulation of recombinant inbred bean lines from a "Jamapa" $\mathrm{x}$ "Calima" population inoculated with two strains of Rhizobium. Ann. Rep. Bean Improv. Coop. 56: 75.

Guadalupe, R., 1977. Influencia de la época de siembra en el comportamiento de la habichuela seca. M.S. Thesis. Univ. of Puerto Rico. Mayagüez, PR.

Haley, S.D., P.N. Miklas, J.R. Stavely, J. Byrum and J.D. Kelly, 1993. Identification of RAPD markers linked to a major rust resistance gene block in common bean. Theor. Appl. Genet. 86: 505-512.

Hart, J., A. Vargas, J.S. Beaver, D.G. Debouck and T.G. Porch, 2019. Genotyping the ex situ genetic resources of wild and cultivated tepary bean. Ann. Rep. Bean Improv. Coop. 62: 109-110.

Heilig, J.A., J.S. Beaver, E.M. Wright, Q. Song and J.D. Kelly, 2017. QTL analysis of symbiotic nitrogen fixation in a black bean population. Crop Sci. 57: 118-129.

Helms, D.M., W.C. Matthews Jr., S.R. Temple and P.A. Roberts, 2004. Registration of 'Cariblanco N' lima bean. Crop Sci. 44: 352-353.

Hendricksen, H.C., 1906. Vegetable growing in Puerto Rico. USDA Puerto Rico Agricultural Experiment Station Bulletin No. 7.58 p.

Hosfield, G.L. and J.S. Beaver, 2001. Cooking time in dry bean and its relationship to water absorption. Ann. Rep. Bean Improv. Coop. 44: 157-158.

Johnson, E., P.N. Miklas, J.R. Stavely and J.C. Martínez-Cruzado, 1995. Coupling- and repulsion-phase RAPDs for marker-assisted selection of PI 181996 rust resistance in common bean. Theor. Appl. Genet. 90: 659-664.

Kaiser, W.J., 1981. Diseases of chickpea, lentil, pigeon pea, and tepary bean in Continental United States and Puerto Rico. Economic Botany 35: 300-320.

Kaiser, W.J. and N.G. Vakili, 1978. Insect transmission of pathogenic Xanthomonads to bean and cowpeas in Puerto Rico. Phytopathology 68: 1057-1063.

Kamfwa, K., J.S. Beaver, K.A. Cichy and J.D. Kelly, 2018. QTL mapping of resistance to bean weevil in common bean. Crop Sci. 58: 1-9. doi: 10.2135/cropsci2018.02.0106 
Kelly, J.D., G.V. Varner, P. O’Boyle and B. Long, 2009. Registration of 'Zorro' black bean. J. Plant Reg. 3:226-230.

Kelly, J.D., P. Gepts, P.N. Miklas and D.P. Coyne, 2003. Tagging and mapping of genes and QTL and molecular marker-assisted selection for traits of economic importance in bean and cowpea. Field Crops Res. 82: 135-154.

Koenig, N., 1953. A comprehensive agricultural program for Puerto Rico. United States Department of Agriculture, Washington, D.C. 299 p.

Kusolwa, P.M., J.R. Myers, T.G. Porch, Y. Trukhina, A. González-Vélez and J.S. Beaver, 2016. Registration of AO-1012-29-3-3A red kidney bean germplasm line with bean weevil, BCMV and BCMNV resistance. J. Plant Reg. 10:149-153.

Kusolwa, P.M. and J.R. Myers, 2011. Seed storage proteins ARL2 and its variants from the APA locus of wild tepary bean G40199 conffers resistance to Acanthoscelides obtectus when expressed in common beans. Afr. Crop Sci. J. 19:255-265.

Leonard, M.D and A.S. Mills, 1931. A preliminary report on the lima bean pod-borer and other legume pod-borers in Porto Rico. Journal of Economic Entomology. 24(2): 466-473.

Linares, A.M., C.A. Urrea, T.G. Porch, S. Mamidi, P.E. McClean and J.M. Osorno, 2014. QTL mapping for drought tolerance using a RIL population of Buster x SER 22. Annu. Rep. Bean Improv. Coop. 57: 37-38.

Linares, A.M., C.A. Urrea, T.G. Porch and J.M. Osorno, 2012. A mapping population for the evaluation of drought tolerance in dry bean. Annu. Rep. Bean Improv. Coop. 55: 107108.

Liu, L.C., R. Montalvo-Zapata, J. Ortiz-López and J. A. Rodríguez, 1999. Effect of planting dates and frequencies of intercropping on yield and income of bean and banana. $J$. Agric. Univ. P. R. 83: 209-215.

Liu, L.C., J.A. Rodríguez and J. Ortiz, 1997. Intercropping bean cultivars with plantain. J. Agric. Univ. P. R. 81: 151-158.

López-Guadamuz, M.A., 1976. Identificación de las razas fisiológicas más comunes de la roya [Uromyces appendiculatus (Pers.) Unger] del frijol (Phaseolus vulgaris L.) en Puerto Rico. M.S. Thesis. Univ. of Puerto Rico, Mayagüez, Puerto Rico.

Lozano, J., E. Rivera and F. Abruña, 1983. Effect of season of the year on yields of several varieties of dry beans growing in two ecological regions of Puerto Rico. J. Agric. Univ. P. R. 67: 379-385.

Lucier, G., Biing-Hwan Lin, J. Allshouse and L. Scott Kantor, 2000. Factors affecting dry bean consumption in the United States. USDA. Economic Research Service. https:// www.agmrc.org/media/cms/DryBeanConsumption_06EF5442C497B.pdf

Lugo-López, M.A., J. Badillo-Feliciano and L. Calduch, 1977. Response of native white beans, Phaseolus vulgaris, to various N levels in an Oxisol. J. Agric. Univ. P. R. 61: 438-442.

Lugo-López, M.A., B.G. Capó, F. Aróstegui and A. Riollano, 1953. Intercropping sugarcane with food crops. J. Agric. Univ. P. R. 37:171-182.

Lugo-Mercado, H.M., J. Badillo-Feliciano and F.H. Ortiz-Alvarado, 1984. Effects of no tillage and various tillage methods on yields of maize, field beans and pepper grown on a Mollisol in southern Puerto Rico. J. Agric. Univ. P. R. 68:349-354.

Macchiavelli, R. and J.S. Beaver, 2001. Effect of number of seed bulked and population size on genetic variability when using the multiple-seed procedure of SSD. Crop Sci. 41: 1513-1516.

Mackie, W.W., 1943. Origin, dispersal and variability of the lima bean (Phaseolus vulgaris L.). Hilgardia 15(1): 1-29.

Mangual-Crespo, G., R. Kluson and E.C. Schroder, 1987. Nitrogen levels and Rhizobium inoculation and yields of native white bean (Phaseolus vulgaris L). J. Agric. Univ. P. R. 71:1-6.

Mangual-Crespo, G. and A.L. González, 1981. Preliminary evaluation of a snap bean harvester in southern Puerto Rico. J. Agric. Univ. P. R. 65: 138-141.

Mangual-Crespo, G. and C.J. Torres, 1979. Response of snap beans (Phaseolus vulgaris) to increasing plant density. J. Agric. Univ. P. R. 63: 465-468.

Mangual-Crespo, G., 1977. Effect of two harvesting systems on the yield and seed percentage of snap beans, Phaseolus vulgaris, in the Isabela area. J. Agric. Univ. P. R. 61: 275-278. 
Mangual-Crespo, G., 1975. Effect of time of planting on the marketable yield of two snap bean varieties at Isabela, Puerto Rico. J. Agric. Univ. P. R. 59: 219-221.

Martínez, M., 1984. Estudio del efecto de las cuatro razas del nematodo nodulador (Meloidogyne incognita) sobre cultivares de habichuela. M.S. Thesis. Univ. of Puerto Rico. Mayagüez, PR.

Martínez, R.T., J.S. Beaver, F. Saladin and D.P. Maxwell, 1991. Lack of seed transmission by bean golden mosaic gemnivirus from the Dominican Republic and Puerto Rico. Ann. Rep. Bean Improv. Coop. 34: 17.

Martínez-Figueroa, H.D., 2017. Desarrollo de líneas de frijol (Phaseolus vulgaris L.) que combinen resistencia a mustia hilachosa [Thanatephorus cucumeris Frank (Donk)], bacteriosis común (Xanthomonas axonopodis pv. phaseoli) y los virus BGYMV, BCMV y BCMNV. M.S. Thesis. Univ. of Puerto Rico, Mayagüez, PR.

Mateo, B., 2016. Selección de líneas de frijol que combinan resistencia al gorgojo común con resistencia a los virus BGYMV, BCMV y BCMNV. M.S. Thesis, University of Puerto Rico, Mayagüez, Puerto Rico.

Mateo-Solano, M., J.S. Beaver and F. Saladín-García, 1989. Heritabilities and phenotypic correlations of morphological traits of beans. J. Agric. Univ. P. R. 73: 349-360.

Matz, J., 1921. The Rhizoctonias of Porto Rico. J. Dept. Agric.Porto Rico 5(1): 1-31.

Maxwell, D., S. Hanson, R. Hoogstraten, P. Alquist, J. Beaver, O. Azzam and J. Karkashian, 1994. Genome organization and functions of bean golden mosaic gemnivirus. p. 119-124. In Bean Golden Mosaic - 1994 Research Advances. F. Morales (ed.). Centro Internacional de Agricultura Tropical (CIAT), Cali, Colombia.

Meléndez, P., R. Rodríguez and L. Wessel-Beaver, 1986. Bean rust control under field conditions with systemic and contact fungicides. J. Agric. Univ. P. R. 70: 45-55.

Melotto, M. and J.D. Kelly, 1998. SCAR markers linked to major disease resistance genes in common bean. Ann. Rep. Bean Improv. Coop 41: 31-32.

Melotto, M., L. Afanador and J.D. Kelly, 1996. Development of a SCAR marker linked to the $I$ gene in common bean. Genome 39: 1216-1219.

Meiners, J.P., H.E. Waterworth, F.F. Smith, R. Alconero and R.H. Lawson, 1976. A seedtransmitted strain of Cucumber Mosaic Virus isolated from bean. J. Agric. Univ. P. R. 58: 127-167.

Miklas, P.N., J.R. Smith, S.P. Singh and J.D. Kelly, 2011. Registration of USCR-CBB-20 cranberry dry bean germplasm line with improved resistance to common bacterial blight. J. Plant Reg. 5: 98-102.

Miklas, P.N., J.D. Kelly, S.E. Beebe and M.W. Blair, 2006. Common bean breeding for resistance against biotic and abiotic stresses: From classical to MAS breeding. Euphytica 147: 105-131.

Miklas, P.N., D.P. Coyne, K.F. Grafton, N. Mutlu, J. Reiser, D.T. Lindgren and S.P. Singh, 2003. A major QTL for common bacterial light resistance derives from the common bean great northern landrace cultivar Montana No. 5. Euphytica 131: 137-146.

Miklas, P.N., M.A. Pastor-Corrales, G. Jung, D.P. Coyne, J.D. Kelly, P.E. McClean and P. Gepts, 2002. Comprehensive linkage map of bean rust resistance genes. Annu. Rep. Bean Improv. Coop. 45: 125-129.

Miklas, P.N., V. Stone, M.J. Daley, J.B. Stavely, J.R. Steadman, M.J. Bassett, R. Delorme and J.S. Beaver, 2000. Bacterial, fungal, and viral disease resistance loci mapped in a recombinant inbred common bean population ('Dorado'/XAN176). J. Amer. Soc. Hort. Sci. 125: 476-481.

Miklas, P.N., M. Zapata, J.S. Beaver and K.F. Grafton, 1999. Registration of four dry bean germplasms resistant to common bacterial blight: ICB-3, ICB-6, ICB-8 and ICB-10. Crop Sci. 39: 594.

Miklas, P.N., H.F. Schwartz, R. Nina and J.S. Beaver, 1998a. Reaction of select tepary bean to ashy stem blight and fusarium wilt. HortScience 33: 136-139.

Miklas, P.N., V. Stone, C. A. Urrea, E. Johnson and J.S. Beaver, 1998b. Inheritance and QTL analysis of field resistance to ashy stem blight in common bean. Crop Sci. 38: 916-921.

Miklas, P.N. and J.R. Stavely, 1998. Incomplete dominance of rust in tepary beans. HortScience 33: 143-145. 
Miklas, P.N., J.S. Beaver, J.R. Steadman, M.J. Silbernagel and G.F. Freytag, 1997. Registration of three bean common mosaic virus-resistant navy bean germplasms. Crop Sci. 37: 1025.

Miklas, P.N., L. Afanador and J.D. Kelly, 1996a. Recombination-facilitated RAPD marker-assisted selection for disease resistance in common bean. Crop Sci. 36: 86-90.

Miklas, P.N., E. Johnson, V. Stone, J.S. Beaver, C. Montoya and M. Zapata, 1996b. Selective mapping of QTL conditioning disease resistance in common bean. Crop Sci. 36: 1344-1351.

Miklas, P.N. and J. Santiago, 1996. Reaction of select tepary bean to bean golden mosaic virus. HortScience 31: 430-432.

Miklas, P.N., 1995a. Release of three high protein dry bean germplasm lines: TARSHP70, -HP140, -HP146. Annu. Rep. Bean Improv. Coop. 38: 178-179.

Miklas, P.N., 1995b. Release of six small white-seeded dry bean germplasm lines TARSVR1, -VR1s, -VR7, -VR7s, -VR8, -VR8s. Annu. Rep Bean Improv. Coop. 38: 180-181.

Miklas, P.N., J.S. Beaver, K.F. Grafton and G.F. Freytag, 1994a. Registration of TARS VCI-4B multiple disease resistant germplasm. Crop Sci. 34:1415.

Miklas, P.N., J.C. Rosas, J.S. Beaver, L. Telek and G.F. Freytag, 1994b. Field performance of selected tepary bean germplasm in the tropics. Crop Sci. 34: 1639-1644.

Miles, M.R., M.A. Pastor-Corrales, G.L. Hartman and R.D. Frederick, 2007. Differential response of common bean cultivars to Phakopsora pachyrhizi. Plant Dis. 91: 698704.

Mmbaga, M.T., J.R. Steadman and J.R. Stavely, 1996. The use of host resistance in disease management of rust in common bean. Integrated Pest Management Reviews 1: 191-200.

Molina-Castañeda, A. and J.S. Beaver, 1998. Inheritance of Normal Pod Development in Bean Golden Mosaic Resistant Common Beans. Ann. Rep. Bean Improv. Coop. 41: 3-4.

Montero-Rojas, M., M. Ortiz, J.S. Beaver and D. Siritunga, 2013. Genetic, morphological and cyanogen content evaluation of a new collection of Caribbean Lima bean (Phaseolus lunatus L.) landraces. Genetic Resources and Crop Evolution 60: 22412252.

Montero-Rojas, M., J.S. Beaver and D. Siritunga, 2012. Assessment of genetic diversity among lima bean landraces from the Dominican Republic, Haiti and Puerto Rico. Ann. Rep. Bean Improv. Coop 55: 129-130.

Montoya, C.A., J.S. Beaver, R. Rodríguez, P.N. Miklas and G. Godoy de Lutz, 1997. Heritability of resistance to web blight in five common bean populations. Crop Sci. 37:780-783.

Naderpour, M., O.S. Lund, R. Larsen and E. Johansen, 2010. Potyviral resistance derived from cultivars of Phaseolus vulgaris carrying bc-3 is associated with the homozygotic presence of a mutated eIF4E allele. Mol. Plant Pathol. 11: 255-263.

Navarro, R.B., A. Vargas, E.C. Schroder and P. van Berkum, 1993. Uptake hydrogenase (Hup) in common bean (Phaseolus vulgaris) symbioses. Applied and Environmental Microbiology 59: 4161-4165.

Oladzad, A., T. Porch, J.C. Rosas, S.M. Moghaddam, J. Beaver, S.E. Beebe, J. Burridge, C.N. Jochua, M.A. Miguel, P.N. Miklas, B. Raatz, J.W. White, J. Lynch and P.E. McClean, 2019. Single and multi-trait GWAS identify genetic factors associated with production traits in common bean under abiotic stress environments. G3: Genes, Genomes, Genetics 9: 1881-1892.

Osorno, J.M., C.G. Muñoz, J.S. Beaver, F.H. Ferwerda, M.J. Bassett, P.N. Miklas, T. Ozkcyk and B. Bussey, 2007. Two genes from Phaseolus coccineus confer resistance to Bean Golden Yellow Mosaic Virus in common bean. J. Amer. Soc. Hort. Sci. 132: 530-533.

Oviedo, F., J.S. Beaver and J.R. Steadmen, 1990. Caracterización de la pubescencia acicular en las hojas de genotipos de habichuela. J. Agric. Univ. P. R. 74: 111-119.

Palomino, V.R., 2012. Baysian analysis of a linear mixed model to measure the impact of climate change on yield of common bean for the year 2030 worldwide M.S. Thesis. Univ. of Puerto Rico, Mayagüez, PR. 
Pantoja, A., M.A. Ciomperlik, L. Wiscovitch, N. Gabriel, P. Vázquez and W. Robles, 2005. Establishment and distribution of exotic biological control agents for silverleaf whitefly in Puerto Rico. J. Agric. Univ. P. R. 89: 67-73.

Pastor-Corrales, M.A., 2003. Sources, genes for resistance and pedigrees of 52 rust and mosaic resistant dry bean germplasm lines released by the USDA Beltsville bean project in collaboration with Michigan, Nebraska and North Dakota Agricultural Experiment Stations. Ann. Rep. Bean Improv. Coop. 46: 235-241.

Peña, E., A. Pantoja and J. Beaver, 1993. Desarrollo de Bemisia tabaci Genn. sobre cuatro genotipos de Phaseolus vulgaris L. con diferentes grados de pubescencia. J. Agric. Univ. P. R. 77: 61-67.

Perdomo, F., R. Echávez-Badel, M. Alameda and E.C. Schröder, 1995. In vitro evaluation of bacteria for the biological control of Macrophomina phaseolina. World Journal of Microbiology and Biotechnology 11: 183-185.

Picó, R., 1937. Studies in the economic geography of Puerto Rico. The University of Puerto Rico Bulletin. Series VIII. No. 1 pages $80-81$.

Polanco, T., R.P. Rodríguez and J.S. Beaver, 1996a. Microgotas: Método de inoculacion con Rhizoctonia solani Kuhn para la evaluar la reacción de líneas de habichuela (Phaseolus vulgaris L.). J. Agric. Univ. P. R. 80:111-122.

Polanco, T., R.P. Rodríguez and J.S. Beaver, 1996b. Variabilidad entre aislados de Rhizoctonia solani Kuhn. J. Agric. Univ. P. R. 80:195-197.

Porch, T.G., E.I. Brisco-McCann, G. Demosthene, R.W. Colbert, J.S. Beaver and J.D. Kelly, 2020. Release of TARS-LH1 a pinto bean germplasm with resistance to the leafhopper pest. J. Crop Reg. 2020:1-7. doi: 10.1002/plr2.20021

Porch, T.G., K. Cichy, W. Wang, M. Brick, J.S. Beaver, D. Santana-Morant and M. Grusak, 2016. Nutritional composition and cooking characteristics of tepary bean (Phaseolus acutifolius Gray) in comparison with common bean (Phaseolus vulgaris L.). Genetic Resources and Crop Evol. 64: 935-953.

Porch, T.G., J.S. Beaver, G. Abawi, C. Estévez de Jensen and J.R. Smith, 2014a. Registration of a small-red dry bean germplasm, TARS-LFR1, with multiple disease resistance and superior performance in low nitrogen soils. J. Plant Reg. 8: 177-182.

Porch, T.G., S. Valentín, C. Estévez de Jensen and J.S. Beaver, 2014b. Identification of soil-borne pathogens in a common bean root rot nursery in Isabela, Puerto Rico. $J$. Agric. Univ. P.R. 98: 1-14.

Porch, T.G., J.S. Beaver, S. Colon, A. Vargas, Y. Trukhina and C. Estévez de Jensen, 2014c. Development of tools for Macrophomina phaseolina evaluation and for genetic improvement of common beans. Ann. Rep. Bean Improv. Coop 57: 189190.

Porch, T.G., J.S. Beaver and M. Brick, 2013a. Registration of tepary germplasm with multiple-stress tolerance, TARS-Tep 22 and TARS-Tep 32. J. Plant Reg. 7: 358-364.

Porch, T.G., J.S. Beaver, D.G. Debouck, S.A. Jackson, J.D. Kelly and H. Dempewolf, 2013b. Use of wild relatives and closely related species to adapt common bean to climate change. Agronomy 3: 433-461.

Porch T.G. and J.S. Beaver, 2012. Development of improved tepary bean (Phaseolus acutifolius A. Gray) germplasm. Ann. Rep. Bean Improv. Coop. 55: 123-124.

Porch, T.G., C.C. Urrea, J.S. Beaver, S. Valentín, P.A. Peña and J.R. Smith, 2012. Registration of TARS-MST1 and SB-DT1 multiple-stress-tolerant black bean germplasm. J. Plant Reg. 6: 75-80.

Porch, T.G., J.R. Smith, J.S. Beaver and P.D. Griffiths, 2010. TARS-HT-11 and TARSHT-2 Heat-tolerant Dry Bean Germplasm. J. Amer. Soc. Hort. Sci. 45: 1278-1280.

Porch, T.G., V.H. Ramírez, D. Santana and E.W. Harmsen, 2009. Evaluation of common bean for drought tolerance in Juana Diaz, Puerto Rico. J. Agron. Crop Sci. 195: 328334. doi:10.1111/j.1439-037X.2009.00375.x

Porch, T.G., 2006. Application of stress indices for heat tolerance screening of common bean. J. Agron. Crop Sci. 192: 390-394.

PROFRIJOL, 1996. Proceedings of the first international workshop of common bacterial blight. M. Zapata (ed.) held in Mayagüez, Puerto Rico from 19-21 February 1996. Documento 96/2. 324 p. 
Prophete, E., G. Demosthene, G. Godoy de Lutz, T.G. Porch and J.S. Beaver, 2014. Registration of PR0633-10 and PR0737-1 Red Mottled Dry Bean Germplasm Lines with Resistance to BGYMV, BCMV, BCMNV, and Common Bacterial Blight. J. Plant Reg. 8:49-52.

Ramírez, A., 2009. Response of common bean (Phaseolus vulgaris L.) to Rhizobium inoculation and nitrogen fertilization. M.S. Thesis. Univ. of Puerto Rico, Mayagüez, Puerto Rico.

Ramírez, O.D. and J. Vélez-Santiago, 1962. Snap bean variety trials in East-Central Puerto Rico. J. Agric. Univ. P. R. 46: 213-218.

Ramírez, O.D. and R. Abrams, 1960. An evaluation of five pole-bean varieties for a breeding program. J. Agric. Univ. P. R. 44: 31-34.

Ramírez-B., V.H., T.G. Porch and E.W. Harmsen, 2008. Evaporation and water use efficiency for common bean genotypes under non-stress and drought stress conditions. Annu. Rep. Bean Improv. Coop. 51: 82-83.

Ramírez-Builes V.H., T.G. Porch and E.W. Harmsen, 2011. Evaluation of the efficiency of water use in common bean under drought and non-stress conditions in the greenhouse and field. Agron. J. 103: 1206-1215.

Ramírez-Builes, V.H., T.G. Porch and E.W. Harmsen, 2008. Development of linear models for estimation of leaflet area in common bean (Phaseolus vulgaris L.) J. Agric. Univ. P. R. 92: 171-182.

Rivera-Vargas, L., V. Bracero-Acosta and J.S. Beaver, 2007. Temporal and spatial dissemination of Bean Golden Yellow Mosaic Virus (Begomovirus) in Phaseolus vulgaris 'Indeterminate Jamaica Red'. J. Agric Univ. P. R. 91: 207-214.

Rivera-Vargas, L.I., V. Bracero-Acosta, J.S. Beaver, D.E. Purcifull, J.E. Polston and E. Hiebert, 2001. Detecting bean golden yellow mosaic virus in bean breeding lines and in the common legume weed Macroptillium lathyroides in Puerto Rico. J. Agric. Univ. P. R. 85: 165-176.

Rodríguez, A.J., R. Guadalupe and J. R. Cruz, 1979. Quality grading of locally grown snap beans for the fresh market. J. Agric. Univ. P. R. 63: 223-228.

Rodríguez, I.Y., 2017. Análisis fenotípico y genético de frijol tépari (Phaseolus acutifolius A. Gray) para tolerancia a factores bióticos y abióticos. M.S. Thesis. Univ. of Puerto Rico, Mayagüez, PR.

Rodríguez, R. and P. Meléndez, 1986. Effect of fungicide on disease incidence and yield of bean (Phaseolus vulgaris L.) infected with Isariopsis griseola Sacc. and Ascochyta phaseolorum Sacc. J. Agric. Univ. P. R. 70: 127-134.

Rodríguez-Sosa, E.J., I.B. de Caloni, J.R. Cruz Cay and J. Badillo-Feliciano, 1984. Hydration and cooking properties of dry beans. J. Agric. Univ. P. R. 68: 259-267.

Román-Avilés, B. and J. Beaver, 2003. Inheritance of heat tolerance in common bean of Andean origin. J. Agric. Univ. P. R. 87: 113-121.

Román-Avilés, B. and J. Beaver, 2001. Heritability of heat tolerance of an Andean bean population. Annu. Rep. Bean Improv. Coop. 44: 49-50.

Román-Hernández, O. and J.S. Beaver, 1997. Optimum stage of development for harvesting green-shelled beans. J. Agric. Univ. P. R. 80: 89-94.

Rosas, J.C., J.S. Beaver, C. Estévez de Jensen, A. González, D. Rocha-Clavijo and R. Macchiavelli, 2019. Field evaluation of common bean for reaction to web blight and high temperature. J. Agric. Univ. P. R. 102:113-121.

Rosas, J.C., H.D. Martínez-Figueroa, T.G. Porch, C. Estévez de Jensen, A. González and J.S. Beaver, 2018. Evaluation of common bean lines for heat tolerance and web blight resistance. Ann. Rep. Bean Improv. Coop 41: 47-48.

Rosas, J.C., C. Estévez de Jensen and A.G. Vargas, 2012. Biological nitrogen fixation in common bean: research challenges. Ann. Rep. Bean Improv. Coop. Vol. 55: 5-6.

Rosas, J.C., J.S. Beaver, S. Beebe and A. Viana, 2004a. Nomenclatura de variedades de frijol común liberadas en Centro América y El Caribe. Agronomía Mesoamericana 15: 221-224.

Rosas, J.C., J.S. Beaver, D. Escoto, C.A. Pérez, A. Llano, J.C. Hernández and R. Araya, 2004b. Registration of 'Amadeus 77' small red common bean. Crop Sci. 44: 18671868 . 
Rosas, J.C., O.I. Varela and J.S. Beaver, 1997. Registration of 'Tio Canela 75' small red bean. Crop Sci. 37: 1391.

Ruiz, L., J.S. Beaver, J.C. Rosas and E. Ernest, 2010. Evaluation of lima bean landraces from Puerto Rico. Ann. Rep. of the Bean Improvement Coop. 53: 72-73.

Ruiz-Quiles, L.A., 2010. Desarrollo de habichuela (Phaseolus vulgaris L.) con resistencia a BCMV, BGYMV y mejor adaptación en suelos bajos en N. M.S. Thesis. Univ. of Puerto Rico, Mayagüez, PR. 70 p.

Saladin, F., E. Arnaud-Santana, J.C. Nin, G. Godoy de Lutz, J.S. Beaver, D.P. Coyne and J.R. Steadman, 2000. Registration of $\langle$ PC-50 red mottled bean. Crop Sci. 43: 430-431.

Sánchez, A., R. Echávez-Badel, P.R. Hepperly and E.C. Schröder, 1994a. Inoculated common beans are protected against Macrophomina phaseolina by Burkholderia cepacia UPR 5C. Plant and Soil 162: 293-297.

Sánchez, A., R. Echávez-Badel and E.C. Schroder, 1994b. Bean root colonization by Pseudomonas cepacia UPR 5C. J. Agric. Univ. P. R. 78: 59-61.

Schertz, K.F., W. Jurgelsky Jr, and W. Boyd, 1960. Inheritance of antiA1 hemagglutinating activity in lima beans, Phaseolus lunatus. Proc. Nat. Acad. Sci. 46: 529-532.

Schröder, E., 1992. Improvement of the Phaseolus/Rhizobium symbiosis, with particular reference to the Caribbean region. In p.79-96 Biological Nitrogen Fixation and Sustainability of Tropical Agriculture. Mulongoy, K., M. Gueye and D.S.C Spencer (eds.). John Wiley and Sons, New York.

Scott, L.B., 1940. The bean pod borers in Puerto Rico. J. Agric. Univ. P. R. 24: 35-47.

Semidey, N., E. Acevedo, L.E. Flores and A. Aponte, 2007. Estrategias químicas de manejo de malezas en la habichuela (Phaseolus vulgaris L.) con riego por goteo. J. Agric. Univ. P. R. 91: 1-10.

Shaik, M., 1985. Race-nonspecific resistance to Uromyces appendiculatus pv. appendiculatus and its correlation with leaf epidermal characteristics. Phytopathology 75: 478-481.

Shelli-Dessert, K. and F.A. Bliss, 1991. Genetic improvement of food quality factors. p. 649-677. In Common Beans: Research for Crop Improvement. A. van Schoonhoven and O. Voysest (eds). International Center for Tropical Agriculture (CIAT). Cali, Colombia.

Singh, S.P. and P.N. Miklas, 2015. Breeding common bean for resistance to common blight: a review. Crop Sci. 55: 971-984.

Singh, S.P., H. Terán, H.F. Schwartz, K. Otto, D.G. Debouck, W. Roca and M. Lema, 2013. Registration of common bacterial blight resistant dry bean germplasm VAX 1, VAX 3, and VAX 4. Crop Sci. 41: 275-276.

Singh, S.P. and H.F. Schwartz, 2010. Breeding common bean for resistance to diseases: A review. Crop Sci. 50: 2199-2223.

Singh, S.P., F.J. Morales, P.N. Miklas and H. Teran, 2000. Selection for bean golden mosaic resistance in intra- and interracial bean populations. Crop Sci. 40: 1565-1572.

Smith, J.R., S.J. Park, J.S. Beaver, P.N. Miklas, C.H. Canaday and M. Zapata, 2007. Registration of TARS-SR05 multiple disease resistant dry bean germplasm. Crop Sci. 47: 457-458.

Smith, J.R., S.J. Park, P.N. Miklas and C.H. Canaday, 2005. Registration of TARSPT03-1 inter-racial multiple disease-resistant dry bean germplasm. Crop Sci. 45: 1669-1670.

Smith, J.R., 2004. Selection protocols for increased yield and stress tolerance in common bean. J. Agric. Univ. P. R. 88: 27-43.

Smith, J.R. and R. Goenaga, 2004. Field performance of two snap bean cultivars at varying levels of exchangeable aluminum. J. Plant Nutrition 28: 237-246.

Smith, J.R., 2002. Heterodera glycines race 2 and the yield of common bean in Puerto Rico. J. Agric. Univ. P. R. 86: 117-122.

Smit, E., M.R. Garcia-Palmieri, N.R. Figueroa, D.L. McGee, M. Messina, Jo L. Freudenheim, and C.J. Crespo. 2007. Protein and legume intake and prostate cancer mortality in Puerto Rican men. Nutrition and Cancer 58: 146-152. 
Snyder, W.P., 1918. Report of the assistant in plant breeding: Beans. In: Report of the Porto Rico Agricultural Experiment Station 1916, Ed. May, D.W. Government Printing Office, Washington D.C.

Sotomayor-Ríos, A. and S. Torres-Cardona, 1984. Breeding and agronomic studies with sorghum in Puerto Rico. Proceedings of the Caribbean Food Crops Society. 20:289292. http://ageconsearch.umn.edu/record/261618/files/20_71.pdf

Souter, J.R., V. Gurusamy, T.G. Porch and K.E. Bett, 2017. Successful introgression of abiotic stress tolerance from wild tepary bean to common bean. Crop Sci. 57: 11601171.

Stavely, J.R., R.T. McMillan Jr., J.S. Beaver and P.N. Miklas, 2001. Release of three McCaslan type, indeterminate rust and bean golden mosaic resistant snap bean germplasm lines. Ann. Rep. Bean Improv. Coop. 44: 197-199.

Stavely, J.R., R.T. McMillan, J.S. Beaver and P.N. Miklas, 1996. Release of the first rust and bean golden mosaic virus resistant snap bean germplasm for the United States. Phytopathology 86: 8125.

Stavely, J.R., J.R. Steadman, D.P. Coyne and D.T. Lindgren, 1989a. BelNeb Rust Resistant-1 and -2 Great Northern dry bean germplasm. HortScience 24: 400-401.

Stavely, J.R., J.R. Steadman and R.T. McMillan Jr., 1989b. New pathogenic variability in Uromyces appendiculatus in North America. Plant Dis. 73: 428-432.

Stavely, J.R., 1984. Genetics of resistance to Uromyces phaseoli in a Phaseolus vulgaris line resistant to most races of the pathogen. Phytopathology 74: 339-344.

Stavely, J.R., G.F. Freytag, J.R. Steadman and H.F. Schwartz, 1983. The 1983 Bean Rust Workshop. Ann. Rep. Bean Improv. Coop. 26: iv-vi.

Steadman, J.R., G. Godoy de Lutz, J.C. Rosas and J.S. Beaver, 2002a. Uso de un vivero móvil para obtener patrones de virulencia de la roya del frijol común. Agronomía Mesoamericana 13: 37-39.

Steadman, J.R., M.A. Pastor-Corrales and J.S. Beaver, 2002b. An overview of the 3rd bean rust and 2nd bean common bacterial blight international workshops, March 4-8, 2002, Pietermaritzburg, South Africa. Ann. Rep. Bean Improv. Coop. 45: 120124.

Sullivan, J.G. and G. Freytag, 1986. Predicting interspecific compatibilities in beans (Phaseolus spp.) by seed protein electrophoresis. Euphytica 35: 201-209.

Takegami, J.C., J.S. Beaver, G. Godoy de Lutz, R. Echávez-Badel and J.R. Steadman. 2004. Inheritance of web blight resistance in common bean. J. Agric. Univ. P. R. 88: 45-54.

Traub, J., T. Porch, M. Naeem, C.A. Urrea, G. Austic, J.D. Kelly and W. Loescher, 2018. Screening for heat tolerance in Phaseolus spp. using multiple methods. Crop Sci. 58: 2459-2469. doi:10.2135/cropsci2018.04.0275

Tulmann-Neto, A., F.K.S. Koo and J. Cuevas-Ruiz, 1978. Influence of plant competition and pod position on seed yield components and protein content in beans. J. Agric. Univ. P. R. 62: 186-190.

Unander, D.W., R. Diaz-Donaire, J.S. Beaver, J. Cerna-Garcia and D. Rueda, 1989. Yield stability of dry bean genotypes in Honduras. J. Agric. Univ. P. R. 73:339-348.

United States Dry Bean Council, 2019. Production facts. https://www.usdrybeans.com/ industry/production-facts/\#FAQ3no2

U.S. Dept. of Agriculture-NASS, 2012. Census of Agriculture. https://www.nass.usda. gov/Publications/AgCensus/2012/Full_Report/Puerto_Rico/prv1.pdf

U.S. Treasury Dept., 1893. Quarterly Reports of the Chief of the Bureau of Statistics Relative to the Imports, Exports, Immigration and Navigation of the U.S. Government Printing Office, Washington, D.C.

Urrea, C.A. and T. Porch, 2010. Phenotypic evaluation of a subset of the Phaseolus vulgaris core collections, the $P$. acutifolius germplasm collection, and cultivars for drought tolerance in Nebraska and Puerto Rico. Annu. Rep. Bean Improv. Coop. 53: 164-165.

Urrea, C.A., P.N. Miklas and J.S. Beaver, 1999. Inheritance of resistance to common bacterial blight in four tepary bean lines. J. Amer. Soc. Hort. Sci. 124: 24-27 
Urrea, C.A., P.N. Miklas, J.S. Beaver and R.H. Riley, 1996. A codominant randomly amplified polymorphic DNA (RAPD) marker useful for indirect selection of bean golden mosaic virus resistance in common bean. J. Amer. Soc. Hort. Sci. 12: 10351039 .

Vakili, N.G., 1979. Notice to plant breeders of release of multiple disease resistant scarlet runner bean germplasm. http://arsftfbean.uprm.edu/bean/wp-content/uploads/2018/03/Release-of-multiple-disease-resistant-scarlet-runner-bean-germplasm-1979.pdf.

Vakili, N.G., 1976. Annual report. Mayagüez Institute of Tropical Agriculture, Mayagüez, Puerto Rico.

Vakili, N.G. and K.R. Bromfield, 1976. Phakopsora rust on soybean and other legumes in Puerto Rico. Plant Dis. Rep. 60: 995-999.

Vakili, N.G., W.J. Kaiser, J.E. Pérez and A. Cortés-Monllor, 1974. Bacterial blight of beans caused by two Xanthomonas pathogenic types from Puerto Rico. Phytopathology 65: 501-503.

Valentín-Torres, S., M.M. Vargas, G. Godoy de Lutz, T.G. Porch and J.S. Beaver, 2016. Isolates of Rhizoctonia solani can produce both web blight and root rot symptoms in common bean (Phaseolus vulgaris L.). Plant Disease 100: 1351-1357.

Varela, O., J.S. Beaver, M. Zapata, P. Miklas and S. Cianzio, 1996. Evaluación de frijol (Phaseolus vulgaris L.) en generaciones tempranas para resistencia a Xanthomonas campestris pv. phaseoli (Smith) Dye. J. Agric. Univ. P. R. 80: 55-63.

Vargas, A., T.G. Porch and J.S. Beaver, 2014. Evaluation of the tepary bean (Phaseolus acutifolius) CIAT germplasm collection for response to common bacterial blight and bean common mosaic necrosis virus. Annual Report of the Bean Improvement Cooperative 57: 181-182.

Vargas-Palacios, A.M., 2016. Estudio de la reacción al Virus del Mosaico Necrótico Común del frijol (BCNMV) y la habilidad de fijación biológica del nitrógeno (FBN) en frijol tépari (Phaseolus acutifolius A. Gray) e introgresión de la FBN al frijol común (Phaseolus vulgaris L.). M.S. Thesis. Univ. of Puerto Rico, Mayagüez, Puerto Rico.

Velázquez, Y.A., R.A. Kluson and E.C. Schröder, 1988. Rhizobium inoculation of Phaseolus vuulgaris in Lajas, Puerto Rico. J. Agric. Univ. P. R. 72: 427-436.

Velez, J., M.J. Bassett, J.S. Beaver and A. Molina, 1998. Inheritance of resistance to bean golden mosaic virus in common bean. J. Amer. Soc. Hort. Sci. 123: 628-631.

Vélez-Martínez, H., J. López-Rosa and G.F. Freytag, 1989. Determination of yield loss caused by rust (Uromyces phaseoli) in common bean (Phaseolus vulgaris L.) in Puerto Rico. Ann. Rep. Bean Improv. Coop. 32: 134-135.

Vega, B., J.S. Beaver, C. Estévez de Jensen and J.R. Steadman, 2009. First report of bean rust caused by Uromyces appendiculatus Race 19-63 in Puerto Rico. Plant Health Progress. https://www.plantmanagementnetwork.org/pub/php/brief/2009/beanrust/ beanrust.pdf.

Vega, B. and C. Estévez de Jensen, 2010. Virulence of Phakopsora meibomiae in wild and cultivated legumes in Puerto Rico. J. Agric. Univ. P.R. 94:211-224.

Vicente, N.E., A. Ayala and N. Acosta, 1987. Influence of temperature and soil type on the histopathology of Meloidogyne incognita on snap beans. J. Agric. Univ. P. R. 71: 97-105.

Vicente-Chandler, J., R. Costas and E. Boneta, 1966. High crop yield produced with or without tillage on three typical soils on the humid region of Puerto Rico. J. Agric. Univ. P.R. 50: 146-50.

Viehoever, A., 1940. Edible and poisonous beans of the lima bean type (Phaseolus lunatus L.): comparative study including other similar beans. Thail Sci Bull 2: 1-99.

Viteri, D.M. and A.M. Linares, 2019. Inheritance of ashy stem blight resistance in Andean common bean cultivars 'Badillo' and 'PC 50' and genetic relationship between Andean A 195 and 'PC 50'. Euphytica 215: 12. https://doi.org/10.1007/s10681-0192336-2.

Viteri, D.M. and A.M. Linares, 2017. Reaction of Phaseolus spp. genotypes to ashy stem blight caused by Macrophomina phaseolina. Euphytica 213: 199. 
Viteri, D.M., H. Terán, M. C. Asensio-S.-Manzanera, C. Asensio, T.G. Porch, P.N. Miklas and S.P. Singh, 2014. Progress in breeding Andean common bean for resistance to common bacterial blight. Crop Sci. 54: 2084-2092.

Wallace, D.H., K.S. Yourstone, J.P. Baudoin, J. Beaver, D.P. Coyne, J.W. White and R.W. Zobel, 1995. Photoperiod $\mathrm{x}$ temperature effects on the days to flowering of bean (Phaseolus vulgaris L.). p. 863-891. In M. Pessarakli (ed.) Handbook of Plant and Crop Physiology. Marcel Dekker, New York.

Wallace, D.M., J.P. Baudoin, J.S. Beaver, D.P. Coyne, D.E. Halseth, P.N. Masaya, H.M. Munger, J.R. Meyers, M. Silbernagel, K.S. Yourstone and R.W. Zobel, 1993. Improving efficiency of breeding for higher crop yields. Theoretical and Applied Genetics $86: 27-40$.

Wasonga, C.J., M.A. Pastor-Corrales, T.G. Porch and P.D. Griffiths, 2010. Targeting gene combinations for broad spectrum rust resistance in heat tolerant snap beans developed for tropical environments. J. Am. Soc. Hortic. Sci. 135: 521-532.

Wolcott, G., 1933. The lima bean pod-borer caterpillars of Puerto Rico. J. Agric. Univ. P. R. 17: 241-245.

Wyatt, J.E., G. Fassuliotis, A.W. Johnson, J.C. Hoffman and J.R. Deakin, 1980. B4175 root-knot nematode resistant snap bean breeding line. HortSci. 15: 530.

Zaiter, H.Z., D.P. Coyne, J.R. Steadman and J.S. Beaver, 1990. Inheritance of leaf pubescence and resistance to a rust strain in beans. J. Amer. Soc. Hort. Sci. 115: 158.

Zapata, M., J.S. Beaver and T.G. Porch, 2012. Ribotype characterization of Xanthomonas axonopodis pv. phaseoli pathogenic race XAPV1. Ann. Rep. Bean Improv. Coop 55: 119-120.

Zapata, M., J.S. Beaver and T.G. Porch, 2011. Dominant gene for common bean resistance to common bacterial blight caused by Xanthomonas axonopodis pv. phaseoli. Euphytica 179: 373-382.

Zapata, M., 2006. Proposed of a uniform screening procedure for the evaluation of variability of Xanthomonas axonopodis pv. phaseoli and resistance on leaves of Phaseolus vulgaris under greenhouse conditions. Ann. Rep. Bean Improv. Coop 49: 213214.

Zapata, M. and J. S. Beaver, 2005. Differential leaf reaction of common bean lines to pathogenic races of Xanthomonas axonopodis pv. phaseoli from Costa Rica, Nicaragua and Puerto Rico. Ann. Rep. Bean Improv. Coop. 48: 104-105.

Zapata, M., G. Freytag and R. Wilkinson, 2004. Release of five common bean germplasm lines resistant to common bacterial blight: W-BB-11, W-BB-20-1, W-BB-35, W-BB52 and W-BB-11-56. J. Agric. Univ. P. R. 88: 91-95.

Zapata, M. and J.S. Beaver, 2002. Common bacterial blight studies in the Caribbean and Central America. Ann. Rep. Bean Improv. Coop. 45: 166-167.

Zapata, M., R. Rodríguez and S. Singh, 1998. Sources of resistance to Xanthomonas campestris pv. phaseoli from different geographical origins. Ann. Rep. Bean Improv. Coop. 41: 58-59.

Zapata, M., 1997a. Identification of Xanthomonas campestris pv. phaseoli races in Phaseolus vulgaris leaves. Agronomía Mesoamericana 8: 44-52.

Zapata, M., 1997b. Hypersensitive reaction of tepary bean upon inoculation with the common bean blight pathogen. J. Agric. Univ. P. R. 81: 181-190.

Zapata, M., 1996a. Pathogenic variability of Xanthomonas campestris pv. phaseoli. Ann. Rep of the Bean Improv. Coop. 39: 136-137.

Zapata, M., 1996b. Identification of Xanthomonas campestris pv. phaseoli races using Phaseolus vulgaris L. leaves. First International Workshop of Bean Common Bacterial Blight. University of Puerto Rico PROFRIJOL Document 96/2. Pages 54-68.

Zapata, M., R. Cienfuegos, W. Mercado and J.S. Beaver, 1994. Seedborne bacteria in relation to common blight disease incidence on Phaseolus vulgaris L. Ann. Rep. Bean Improv. Coop. 37: 57-58.

Zapata, M., R. Wilkinson, G.F. Freytag, H. Vélez, F.H. Ortiz and J.H. López-Rosa, 1991. Incorporating resistance to Xanthomonas campestris pv. phaseoli into bean using the latent period as a resistance marker. J. Agric. Univ. P.R. 75(4): 345-352. 
Zapata, M., 1989. Host pathogen interaction of the tepary bean, Phaseolus acutifolius with the common bean pathogen, Xanthomonas campestris pv. phaseoli. Ph.D. Dissertation. Univ. of Nebraska.

Zapata, M. and A.K. Vidaver, 1987. Differentiation of Xanthomonas campestris pv. phaseoli into pathogenic races based on the tepary bean reactions. Phytopathology 77: 1709 .

Zapata, M., G.F. Freytag and R. Wilkinson, 1985. Evaluation for bacterial blight resistance in bean. Phytopathology 75: 1032-1039. 